
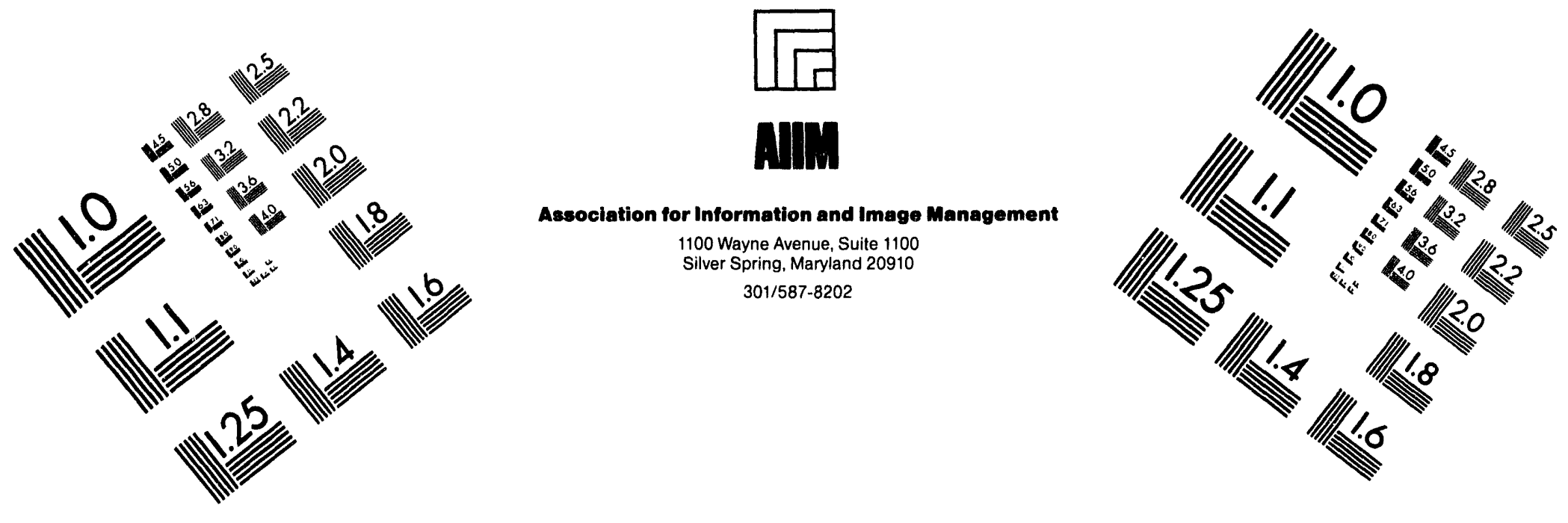

\title{
Centimeter
}

$\begin{array}{llllllllllllllll}1 & 2 & 3 & 4 & 5 & 6 & 7 & 8 & 9 & 10 & 11 & 12 & 13 & 14 & 15 & \mathrm{~mm}\end{array}$

Lши

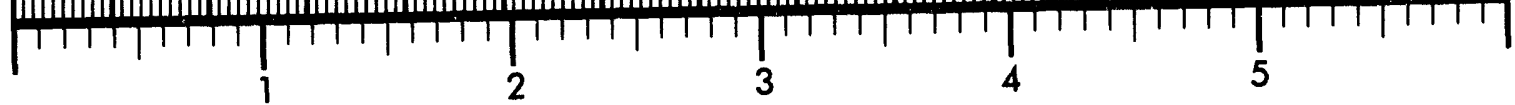
Inches
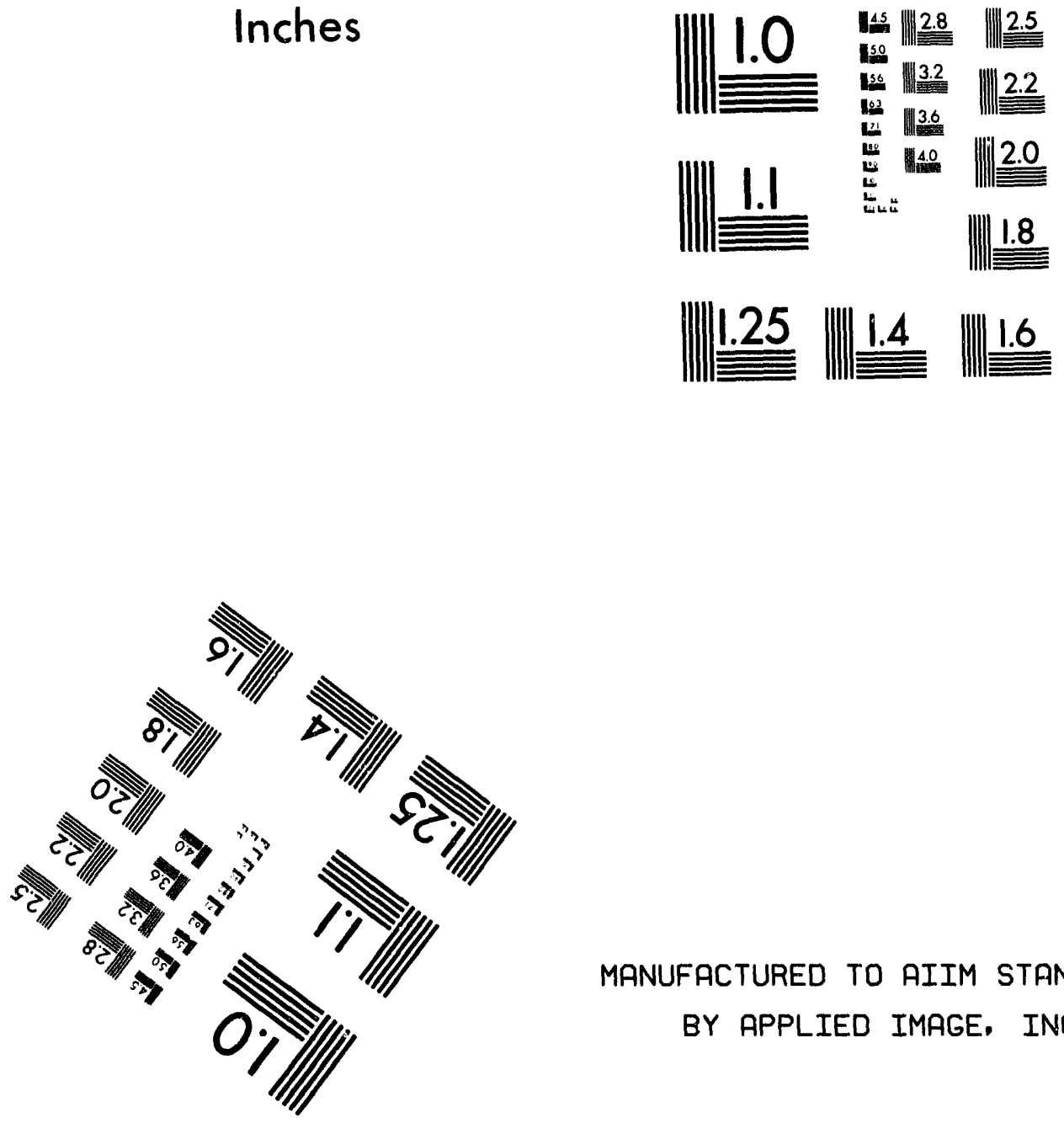

MANUFACTURED TO AIIM STANDARDS BY APPLIED IMAGE, INC.

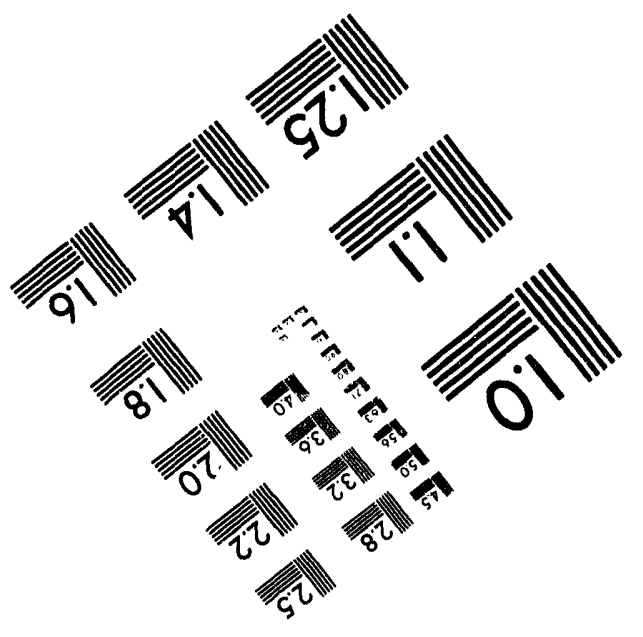



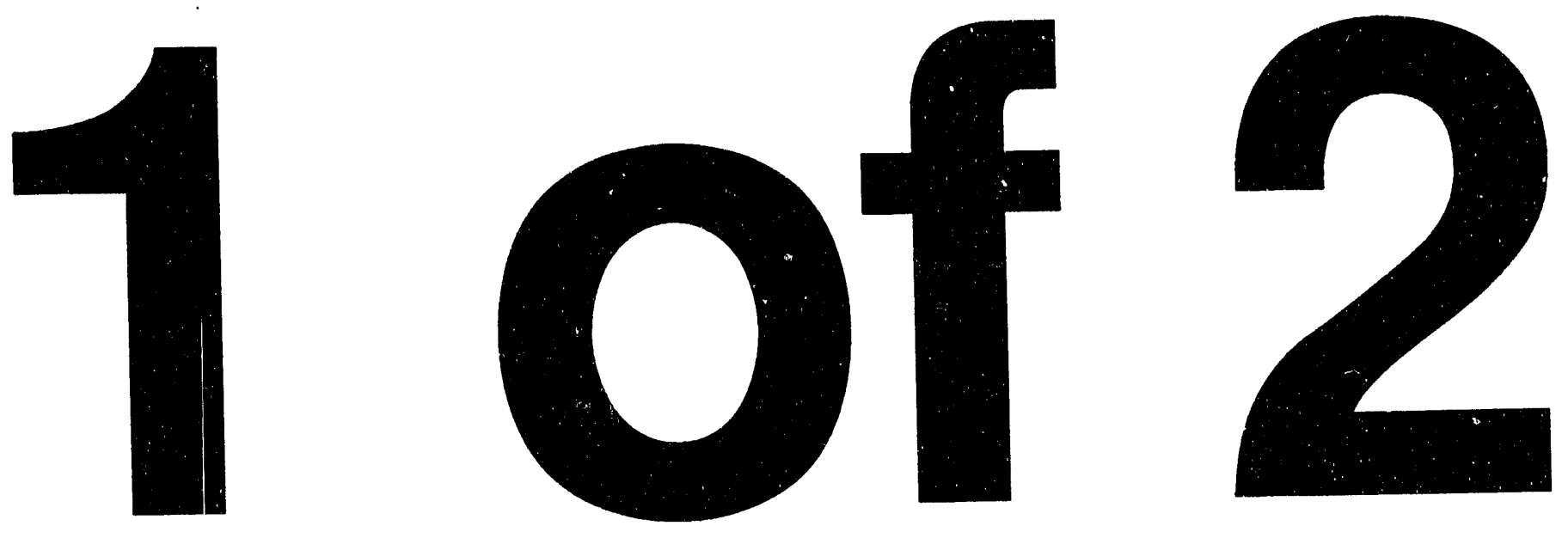
NUREG/CR-4409

BNL-NUREG-51934

Vol. 5

\section{Data Base on Dose Reduction Research Projects for Nuclear Power Plants}

Manuscript Completed: March 1994

Date Published: May 1994

Prepared by

T. A. Khan, C. K. Yu

A. K. Roecklein, NRC Project Manager

Brookhaven National Laboratory

Upton, NY 11973

\section{Prepared for}

Division of Regulatory Applications

Office of Nuclear Regulatory Research

U.S. Nuclear Regulatory Commission

Washington, DC 20555-0001

NRC FIN A3259

\section{DISCLAIMER}

This report was prepared as an account of work sponsored by an agency of the United States Government. Neither the United States Government nor any agency thereof, nor any of their employees, makes any warranty, express or implied, or assumes any legal liability or responsibility for the accuracy, completeness, or usefulness of any information, apparatus, product, or process disclosed, or represents that its use would not infringe privately ov/ned rights. Reference herein to any specific commercial product, process, or service by trade name, trademark, manufacturer, or otherwise does not necessarily constitute or imply its endorsement, recommendation, or favoring by the United States Government or any agency thereof. The views and opinions of authors expressed herein do not necessarily state or reflect those of the United States Government or any agency thereof. 


\begin{abstract}
This is the fifth volume in a series of reports that provide information on dose reduction research and health physics technology for nuclear power plants. The information is taken from two of several databases maintained by Brookhaven National Laboratory's ALARA Center for the Nuclear Regulatory Commission.

The research section of the report covers dose reduction projects that are in the experimental or developmental phase. It includes topics such as steam generator degradation, decontamination, robotics, improvements

section on health physics technology discusses dose reduction efforts that are in place or in the process of being implemented at nuclear power plants. A total of 105 new or updated projects are described.

All project abstracts from this report are available to nuclear industry professionals with access to a fax machine through our ACEFAX system or a computer with a modem and the proper communications software through our ACE system. Detailed descriptions of how to access all our databases electronically are in the appendices of the report.
\end{abstract} in reactor materials, and inspection techniques. The 


\section{CONTENTS}

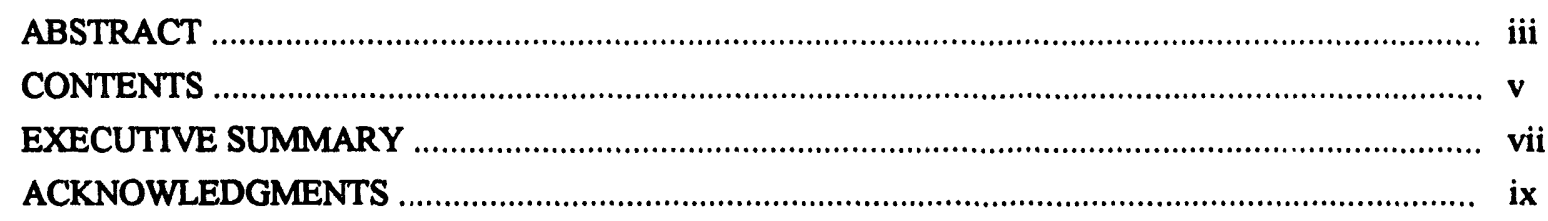

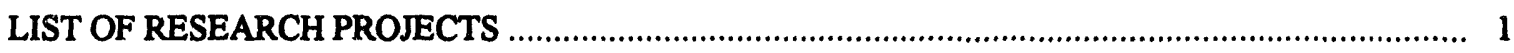

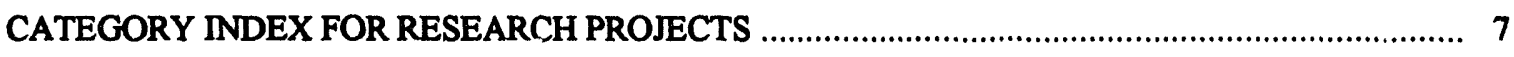

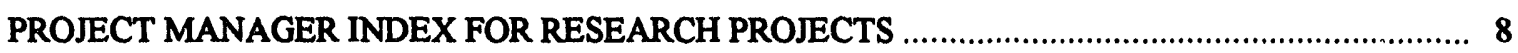

PRINCIPAL INVESTIGATOR INDEX FOR RESEARCH PROJECTS …................................... 9

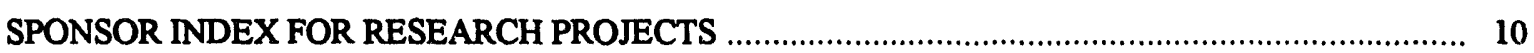

CONTRACTOR INDEX FOR RESEARCH PROJECTS ................................................... 11

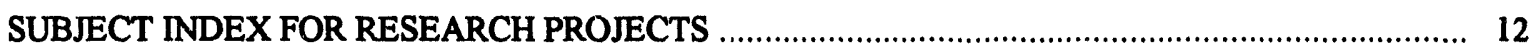

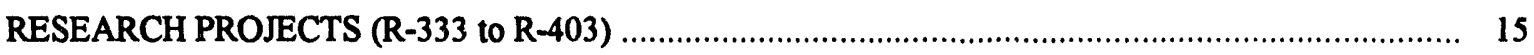

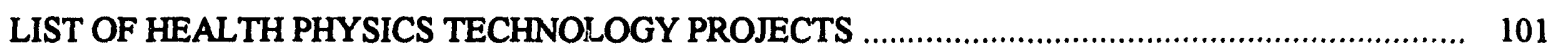

CATEGORY INDEX FOR HEALTH PHYSICS TECHNOLOGY PROJECTS .................................... 105

PROJECT MANAGER INDEX FOR HEALTH PHYSICS TECHNOLOGY PROJECTS ..................... 106

PRINCIPAL INVESTIGATOR INDEX FOR HEALTH PHYSICS TECHNOLOGY PROJECTS .......... 107

SPONSOR INDEX FOR HEALTH PHYSICS TECHNOLOGY PROJECTS …................................... 108

CONTRACTOR INDEX FOR HEALTH PHYSICS TECHNOLOGY PROJECTS ............................. 109

SUBJECT INDEX FOR HEALTH PHYSICS TECHNOLOGY PROJECTS ................................... 110

HEALTH PHYSICS TECHNOLOGY PROJECTS (H-175 to H-208) ........................................... 112

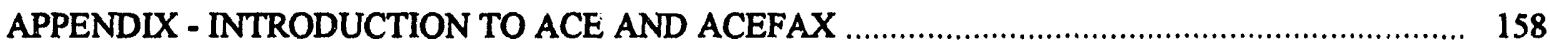

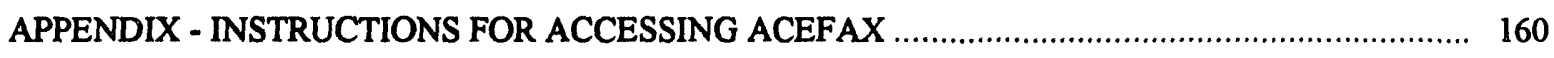

APPENDIX - LIST OF DOCUMENTS ON ACEFAX ......................................................... 161

APPENDIX - INFORMATION ON THE SOFTWARE FOR ACCESSING ACE ….......................... 176

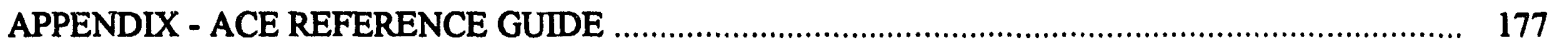

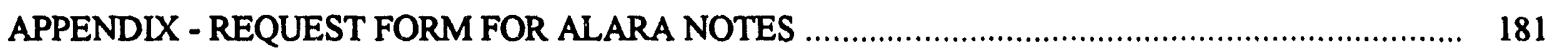

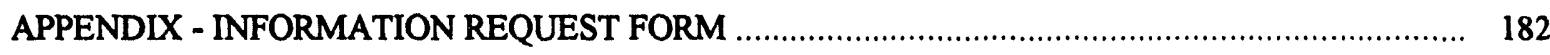




\section{EXECUTIVE SUMMARY}

As part of a project sponsored by the U.S. Nuclear Regulatory Commission, the ALARA Center of Brookhaven National laboratory maintains a number of databases containing information on dose reduction efforts and various aspects of ALARA. Two of these databases are on dose reduction research and health physics technology. The research database consists of the latest findings on ways of reducing doses in nuclear power plants. The information is derived from conferences and industry and government contacts. It includes experimental cobalt reduction methods, primary coolant chemistry studies, progress on full system decontaminations, operational and maintenance techniques, robotics, and other chemical and engineering research programs. The health physics technology database contains information on applied efforts at nuclear power plants which are intended to reduce radiation exposure levels. Examples include radiation shielding during outages, decontaminations, innovative worker training programs, shutdown chemistry guidelines, etc. This report summarizes all the new or updated information from early 1992 to early 1994. It represents 71 research projects and 34 health physics technology projects. (Earlier projects are described in Vol. 1 to 4 of NUREG/CR-4409. They may also be accessed via the ACE or ACEFAX system mentioned below.)

There are two major sections in this volume: research and health physics technology. Each section contains a set of indices that classify the information by title, category, project manager, principal investigator, sponsor, contractor, and subject. The categories are broadly defined areas under which the dose reduction projects are placed. By looking for projects in a particular category the reader will also be made aware of other projects related to the specific subject and yet not be encumbered by projects on topics of less interest.

This report is not designed to give all the details of a project. The purpose is to provide the main objectives, describe some of the most interesting aspects, summarize the conclusions, and provide information on whom to $a$ intact for further details. Of particular interest to the ALARA Center is any quantitative implications as far as exposures and exposure rates are concerned. For more information on a project, the reader is referred to the reference section and/or the principal investigators and project managers.

The contents of this report is also available from the ALARA Center in two other forms. First, all the project iniormation is accessible through our ALARA Center Exchange, or ACE, on-line coinputer database system. This system can be accessed by means of a personal computer, modem, and the appropriate communications software. The user may do a subject search or simply browse through the databases easily and rapidly. One can then print the forms of interest on-line or capture screens containing iseful information for off-line printing.

The second method for information retrieval is to request a fax of the forms of interest via ACEFAX, our ALARA Center Exchange FAX-on-demand system. It allows users to call from the handset of a fax machine, choose the project documents of interest in response to voice prompts, and fax the documents to themselves. Both the ACE and ACEFAX systems are described in detail in the appendix of this report.

The ALARA Center also periodically publishes ALARA Notes, a newsletter devoted to issues of interest to the nuclear power/radiation protection community. It is mailed to about 1300 nuclear professionals in industry, government, and academia. A registration form for inclusion in the mailing list for ALARA Notes is in the appendix. 


\section{ACKNOWLEDGMENTS}

We thank all project managers and principal investigators for providing information on their projects. We acknowledge the contribution of the people who have discussed with us related research activities and health physics programs. We thank Alan Roecklein, the NRC project manager, for his support of this work. We would like to acknowledge the advice and support of John Baum of the Brookhaven National Laboratory. We also express our thanks to Maria Beckman, our secretary, for her help in producing this report. Finally, we thank the members of the ALARA Center's industry advisory committee for reviewing this document and providing their valuable comments. The members of the advisory committee are:

C. Bergmann

R. Giordano

C. Hinson

G. Hudson

T. Murphy

H. Ocken

G. Powers

F. Rescek

F. Roddy

M. Rossler

J. Schmitt

J. Sears
Westinghouse Electric Corporation

General Electric

U.S. Nuclear Regulatory Commission

Tennessee Valley Authority

U.S. Nuclear Regulatory Commission

Electric Power Research Institute

U.S. Nuclear Regulatory Commission

Commonwealth Edison Company

Bechtel Power Corporation

Edison Electric Institute

Nuclear Management \& Resources Council

Niagara Mohawk Power Corporation 
LIST OF RESEARCH PROJECTS 


\section{NUMBER TITLE}

R-333 BWR UNDERWATER DISASSEMBLY/ASSEMBLY - WETLIFT 2000

R-334 PWR PRIMARY SYSTEM CHEMISTRY: EXPERIENCE WITH ELEVATED PH AT MILLSTONE POINT UNIT 3

R-335 STEAM GENERATOR DOSE RATES AT BABCOCK \& WILCOX REACTORS

R-336 PRECONDITIONING OF PWR STEAM GENERATORS TO REDUCE RADIATION BUILDUP

R-337 WELDING OF NOREM IRON-BASE HARDFACING ALLOY WIRE PRODUCTS - PROCEDURES FOR GAS TUNGSTEN ARC WELDING

R-338 ENDURANCE TESTS OF VALVES WITH COBALT-FREE HARDFACING ALLOYS

R-339 REPLACEMENT OF PINS AND ROLLERS IN IRRADIATED BWR CONTROL BLADES

R-340 SECONDARY HYDRIDING OF DEFECTED ZIRCALOY-CLAD FUEL RODS

R-341 TESTING OF AN ORGANIC REMOVAL PROCESS IN BWR RADWASTE SYSTEMS

R-342 EVALUATION OF REACTOR PRESSURE VESSEL HEAD CRACKING IN TWO DOMESTICS BWRS

R-343 RELATIONSHIP OF RADIATION-INDUCED SEGREGATION PHENOMENA TO IRRADIATION-ASSISTED STRESS CORROSION CRACKING (IASCC)

R-344 LIGHT WATER REACTOR MATERIALS AND WATER CHEMISTRY STUDIES AT HALDEN

R-345 PWR IN-PILE LOOP STUDIES IN SUPPORT OF COOLANT CHEMISTRY OPTIMIZATION

R-347 CIIEMISTRY PARAMETERS INFLUENCING THE DOSE RATE BUILD-UP IN BWR PLANTS 
R-348 OVERVIEW OF ACTIVITIES FOR THE REDUCTION OF DOSE RATES IN SWISS BOILING WATER REACTORS

R-349 OPERATING EXPERIENCE OF JAPANESE IMPROVEMENT AND STANDARDIZATION BWRS AND BEHAVIOR OF RADIOACTIVITY IN REACTOR WATER

R-350 FEEDWATER IRON CRUD REDUCTION FOR CHINSHAN NUCLEAR POWER STATION

R-351 REACTIONS OF IRON CRUD WITH METALLIC IONS UNDER BWR WATER CONDITIONS

R-352 DECOMPOSITION OF HYDROGEN PEROXIDE IN BWR COOLANT CIRCUIT

R-353 FULL PRIMARY SYSTEM CHEMICAL DECONTAMINATION QUALIFICATION PROGRAM

R-354 FULL SYSTEM DECONTAMINATION AND COUNTERMEASURES AGAINST RECONTAMINATION OF THE FUGEN NUCLEAR POWER STATION

R-355 ELECTROCHEMICAL CORROSION POTENTIAL MEASUREMENT WITH A ROTATING CYLINDER ELECTRODE IN $288^{\circ} \mathrm{C}$ WATER

R-356 EFFECTS OF ZINC ADDITIONS ON THE CRACK GROWTH RATE OF SENSITIZED STAINLESS STEEL AND ALLOYS 600 AND 182 IN $288^{\circ} \mathrm{C}$ WATER

R-357 ONLINE MEASUREMENT OF PARTICLES IN REACTOR WATER OF BWRS

R-358 THE INTEGRITY OF INCONEL ALLOYS IN HIGH TEMPERATURE WATER CHEMISTRY

R-359 ENRICHED BORON PRODUCTS

R-360 VARIABILITIES IN THE CALCULATION OF PWR PRIMARY COOLANT PH

R-361 CONSTRUCTION AND OPERATION OF AN IN-PILE LOOP FOR BWR COOLANT CHEMISTRY STUDIES 
R-362 WATER CHEMISTRY DURING THE SHUT-DOWN OF THE BOILING WATER REACTOR LEIBSTADT

R-363 SOLUBILITY OF COBALT IN PRIMARY CIRCUIT SOLUTIONS

R-364 STATISTICAL ANALYSIS OF REACTOR WATER DATA

R-365 MIXED OXIDE-ALLOY-WATER SYSTEMS UNDER LWR CONDITIONS

R-366 MAXIMUM ALLOWABLE CHLORIDE LEVELS ON STAINLESS STEEL COMPONENTS AT THE SIZEWELL "B" PWR

R-367 INORGANIC SEED MATERIALS FOR THE DECONTAMINATION OF PWR AQUEOUS WASTES

R-368 EASY INEXPENSIVE HYDROGEN WATER CHEMISTRY PREDICTIVE METHODS

R-369 POTENTIAL-PH DIAGRAMS FOR ALLOY-WATER SYSTEMS UNDER LWR CONDITIONS

R-370 IN-PILE LOOP STUDIES OF CLOSE REDUCTION TECHNOLOGIES FOR PWRS AND BWRS; INVESTIGATIONS OF MATERIAL SUSCEPTIBILITY TO CRACKING

R-371 EVALUATION OF FACTORS AFFECTING RADIATION FIELD TRENDS IN WESTINGHOUSE-DESIGNED PLANTS

R-372 THE MECHANICS AND KINETICS OF CORROSION PRODUCT RELEASE FROM CARBON STEEL IN LITHIATED HIGH TEMPERATURE WATER

R-373 INVESTIGATION OF THE CHEMICAL AND PHYSICAL PROPERTIES OF SPINEL OXIDES

R-374 OVERVIEW OF THE IMPACT OF STELLITE REMOVAL ON RADIATION FIELDS IN KWU PWRS

R-375 ACTIVITY TRANSPORT AND CORROSION PROCESSES IN PWRS

R-376 FEASIBILITY OF ON-LINE MONITORING OF STRESS CORROSION CRACKING IN ROTATING COMPONENTS

R-377 CONCEPT AND EXPERIENCE OF SYSTEM DECONTAMINATION WITH CORD 
R-378 ELOMIX: A BETTER WAY OF HANDLING THE WASTE FROM DECONTAMINATION

BWR/5 FULL-SYSTEM DECONTAMINATION FEASIBILITY STUDY

R-380 MOVING FROM ULTRA-PURE BWR WATER TO PLANT-TAILORED WATER CHEMISTRY

R-381 EFFECTS OF PH OF PRIMARY COOLANT ON PWR CONTAMINATION

R-382 BEHAVIOR OF PWRS IN SPAIN FOLLOWING CHANGES TO MODIFIED CHEMISTRY AND FUEL SPECIFICATIONS

R-383 REVIEW OF EFFECT OF LITHIUM ON PWR FUEL CLADDING CORROSION

SHUTDOWN CHEMISTRY IN SPANISH PLANTS

R-385 EFFECT OF SURFACE TREATMENT ON RADIOACTIVITY DEPOSITION ON STAINLESS STEEL COUPONS EXPOSED IN DOEL 2

R-386 UTILITY APPROACH TO RADIATION FIELD REDUCTION BY COOLANT CHEMISTRY CONTROL

R-387 LOW PICOLINATE LOMI - UPDATE

R-388 DECONTAMINATION CHEMISTRY: CURRENT ISSUES

R-389 RESIN OXIDATION PROCESS IMPROVEMENTS

R-390 DEVELOPMENT OF FULL SYSTEM DECONTAMINATION FOR BWRS

R-391 FUEL DECONTAMINATION QUALIFICATION PROGRAM

R-392 PACIFIC NUCLEAR FIELD IMPLEMENTATION

R-393 UTILITY DECONTAMINATION EXPERIENCE

R-394 ABB ATOM PROJECT - ALARA 2000

R-395 DEVELOPMENT AND USE OF AN IN-PILE LOOP FOR BWR CHEMISTRY STUDIES

R-396 REPLACEMENT OF PINS \& ROLLERS IN IRRADIATED BWR CONTROL BLADES 
R-397 COBALT SOURCE REDUCTION - CONTROL ROD PIN \& ROLLER REPLACEMENT

R-398 PERFORMANCE OF IRON-BASE HARDFACING ALLOYS IN GATE VALVES TESTED UNDER SIMULATED BWR CHEMISTRY CONDITIONS

R-399 NOREM WEAR-RESISTANT ALLOYS: AN EPRI PROGRAM UPDATE

R-400 THE EFFECT OF ZINC ON CARBON STEEL AND STAINLESS STEEL IN LITHIATED COOLANT

R-401 OPTIMUM WATER CHEMISTRY IN RADIATION FIELD BUILDUP CONTROL

R-402 STATUS REPORT ON BWR FULL SYSTEM DECONTAMINATION

R-403 ACTIVITY PICKUP BY COATED COUPONS EXPOSED IN THE DOEL REACTOR 
Category Index for Research Projects

COMPONENT RELIABILITY

$R 337,340,342-345,355-356,358-359,361,365-366,368-370,376,383,385,395,397-399$ CONTAMINATION PREVENTION

$\mathbf{R} 333,336,338-341,345-352,354,357,360-364,370,372-375,380-382,385-386,395,403$ CONTAMINATION REMOVAL

R339, 353-354, 367, 377-379, 387-393, 402

OPERATIONAL AND MAINTENANCE TECHNIQUES

R334-335, 371, 384, 394, 400-401

RADIATION SHIELDING

R333

REMOTE SYSTEMS

R333, 339, 396 
Project Manager Index for Research Projects

Andresen, $\mathbf{P}$.

Baversten, Bengt

Bergmann, C.

Bertholdt, 0 .

Brélaz, B.

Cubicriotti, D.

Fernandez Lillo, E.

Gunnerud, P.

Haraguchi, $\mathbf{K}$.

Harling, 0 .

Ingemansson, Tor

Joyer, F.

Kitabata, $\mathrm{T}$.

Lawson, W.

Lister, $\mathrm{D}$.

Loner, $\mathrm{H}$.
R356

R333

R371

R377

R348

R365

R384

R344

R349

R345, 361, 370

R394

R363

R354

R366

R346, 372-373

R364
Nelson, J.

Nishino, Y.

Ocken, Howard

Passell, $\mathrm{T}$.

Pathania, R.

Phillips, Michael

Reitzner, U.

Roofthooft, R.

Schenker, E.

Sellers, $\mathbf{R}$.

Syrett, Barry

Wen, $T$.

Wood, Christopher

Yagnik, Suresh
R343

i2351

R334-335, 337-339,

353, 396, 398, 403

R341

R342, 355, 395

R399

R347

R385

R357, 362

R367

R376

R350

R336, 378-379,

387, 389-391

R340 
Principal Investigator Index for Research Projects

\begin{tabular}{llll} 
Alder, H. & R348, 364 & Ingemansson, Tor & R394 \\
Allan, S. & R366 & Karlsen, T. & R344 \\
Allsop, H. & R346, 372, 400 & Lambert, I. & R363 \\
Anthoni, S. & R381 & Lin, C. & R352, 355, 401 \\
Asay, Roger & R403 & Lister, D. & R375 \\
Beaman, T. & R379 & Llovet, R. & R384 \\
Bergmann, Carl & R334 & Marchl, T. & R347 \\
Blaser, W. & R362 & McKenzie, P. & R373 \\
Bradbury, D. & R378, 389 & Miller, P. & R353 \\
Cearley, J. & R397 & Miller, R. & R391 \\
Cheng, T. & R350 & Murphy, E. & R338, 398 \\
Cox, William & R376 & Naoi, Y. & R354 \\
Cubicciotti, D. & R365, 369 & Ohsumi, K. & R349 \\
Diaz, T. & R356 & Perock, J. & R371 \\
Driscoll, M. & R345, 361, 370 & Phillips, M. & R337 \\
Dupin, Michel & R393 & Pick, M. & R385 \\
Fejes, P. & R380 & Polley, M. & R360, 383 \\
Fernandez Lillo, E. & R382 & Ruoss, Christian & R396 \\
Fox, M. & R368 & Sheffield, John & R392 \\
Francioni, W. & R357 & Smee, Jerry & R387 \\
Garbett, K. & R374 & Speranzini, Robert & R388 \\
Goehlich, Veronique & R359 & Stolzenberg, Norman & R339, 396 \\
Gordon, Barry & R390, 402 & Uchida, S. & R351 \\
Head, Robert & R341 & Wille, H. & R377 \\
Hooper, E. & R367 & Wivagg, Peter & R333 \\
Hudson, M. & R386 & Yang, I.J. & R358 \\
\hline
\end{tabular}


ABB Combustion Engineering

$$
\text { R333 }
$$

Asco Chemistry

R384

CEA

\section{R363}

Electric Power Research Institute

R334-337, 338-343, 353, 355, 376, 378, 379, 387, 389-391, 395-396, 398-399, 403

General Electric Corporate R \& D

R356

Hitachi Ltd.

R351

Institute of Nuclear Energy Research

R350

Laborelec

R385

Massachusetts Institute of Technology

R345, 361
Nuclear Electric plc

R366-367

OECD Halden Reactor Project R344

Paul Scherrer Institute R357, 362, 364

Power Reactor and Nuclear Fuel Development Corporation

R354

Siemens AG

R347

Swiss Federal Nuclear Safety Inspectorate R348

The Tokyo Electric Power Co. Inc. R349

University of New Brunswick R346, 372-373

Westinghouse Electric Corporation R371 
1st Nuclear Power Station

R350

ABB Atom AB

R380, 394

ABB Combustion Engineering

R333, 339, 396

AEA Technology

R367

AECL Research

R338, 346, 372, 388, 398, 400

Aptech Engineering Services Inc.

R368

Atomic Energy of Canada, Ltd.

R338, 398

Babcock and Wilcox

R335

Bradtec Ltd.

R378, 389

Capcis March Ltd

R376

CEA

R363

CEA-CEN Cadarache R381

Commissariat A L'Energie Atomique R336

Eagle-Picher Industries Materials $\mathrm{GmbH}$ R359

Electric Power Research Institute R365, 369

EPRI NDE Center

R337, R399

Electricite de France R393

General Electric

R341, 352, 355-356, 397, 390, 401, 402

Hitachi Energy Res. Laboratory

R351

Hitachi Ltd.

R349

Industrial Technology Research Institute

R358
Massachusetts Institute of Technology

R345, 361, 370, 395

Niagara Technical Consultants R387, 379

NNC Ltd.

R366

Northeast Utilities

R386

Nuclear Electric R360, 374, 383, 385

Nuclear Power Plant Leibstadt R362

OECD Halden Reactor Project R344

Pacific Nuclear R392

Paul Scherrer Institute R348, 357, 364

Power Reactor and Nuclear Fuel Development Corporation R354

Radiological \& Chemical Technology R403

Siemens

$$
\text { R347, } 377
$$

Structural Integrity Associates R342

University of California, Berkeley R340

University of New Brunswick R373, 375

Vandellos NPP R382

Westinghouse Electric Corporation R334, 371, 384, 391

Westinghouse Nuclear and Advanced Technology Division R353

Westinghouse Science and Technology Center R343 
Subject Index for Research Projects

ALARA R386

ALKALINE PERMANGANATE R388, 390

ALLOY R338, 356, 358

BORATION R384

BORON R359

CAN-DECON R388

CAN-DEREM R353, 388

CHEMISTRY See Primary Coolant

Chemistry, PWR Coolant, and Water

Chemistry

CHLORIDE R366

CHROMIUM R385

COBALT R337-339, 348-349, 363-364, $371,375,382$

COBALT REDUCTION R386, 396-399, 401

COBALT RELEASE R372-373

COBALT REMOVAL R377

COBALT SOURCE R374-375

CONTROL BLADE R339

CONTROL ROD R397

COOLANT R381

CORD PROCESS R377

CORROSION R340-341, 344, 352, 361, $365,369,375,380,383,390-391,400$

CORROSION CONTROL R345, 380

CORROSION MONITORING R376

CORROSION PRODUCT R362, 375, 380

CORROSION PRODUCT DEPOSITION

R375

CORROSION PRODUCT RELEASE

R372-373

CORROSION PRODUCT TRANSPORT

R375

CORROSION PRODUCT MASSBALANCE R394
CORROSION TESTING $\quad \mathbf{R} 376$

COST REDUCTION R.368

CRUD R350, 375

CRUD TRANSPORT R375

DECONTAMINATION R353-354, 371, 377-379, 387-388, 390-393, 402

DOSE RATE R381, 384

DOSE REDUCTION R338, 349, 354

ELECTROCHEMICAL CORROSION

POTENTIAL R355

ELECTROCHEMICAL POTENTIAL R395

ELECTRON MICROSCOPY R343

ELECTROPOLISHING R385, 403

ELOMIX R378

EMMA R393

ENRICHED BORIC ACID R359

EVALUATION OF DOSE RATE R394

EVERIT $50 \quad$ R398

EXPOSURE REDUCTION R333, 394

FILTRATION R350

FUEL R334

FUEL ASSEMBLY R391

FUEL CLADDING R383, 391

FUEL DECONTAMINATION R391

FUEL FAILURE R394

FUEL ROD CLADDING R340

FULL SYSTEM DECONTAMINATION R353-354, 377, 379, 387-388, 390-392, 402

HARDFACING ALLOY R337-338, 374, 398-399

HYDROGEN R340

HYDROGEN PEROXIDE R352, 362

HYDROGEN WATER CHEMISTRY

R368, 380, 401 
IASCC R343-344

IGSCC R342, 355, 368, 380, 390

INCONEL R336, 358

INORGANIC SEED MATERIAL $\quad$ R367

INTERGRANULAR ATTACK R366

ION CHROMATOGRAPHY R347

ION R351

IRON R338, 347, 350

IRON BASED ALLOY R337

LITHIUM R344, 383, 386

LOMI R353, 378, 387, 390, 402

LOW-ALLOY STEEL R342

LWR R340, 343-344

MATERIALS R398

MATHEMATICAL MODEL R364

MIXED OXIDE R369

N-16 CARRYOVER R370

NICKEL R347, 358

NICKEL ALLOY R343

NITROGEN R361

NITROGEN-16 R395

NOREM R337, 398, 399

NUCLIDE SPECIFIC MEASUREMENT R394

ON-LINE MEASUREMENT R357

ON-LINE MONITORING R376

ORGANIC SUBSTANCE R341

OUTAGE TIME R384

OXIDE FILM R346, 351, 365, 369, 372-373, 383

OXYGEN CONTENT R346-347, 380

OZONE R341

PALLADIUM COATING R385

PARTICULATE R362

PASSIVATION R385

PH R345, 347, 360, 365, 370, 375, 381-382, 386
PH CONTROL R381-382, 386

PINS AND ROLLERS R396-397

PITTING R366

POURBAIX DIAGRAM R369

PRECONDITIONING R385

PREFILMING R403

PREOXIDATION R403

PRIMARY COOLANT CHEMISTRY

R344-349, 352, 361, 363, 380-383, 386

PWR COOLANT R3'75

RADIATION BUILDUP R336, 338, 345-347, 350, 364

RADIATION DOSE R335

RADIATION FIELD R339, 357, 371, 374

RADIATION FIELD CONTROL R371, 379, 382, 386

RADIATION FIELD TREND $\quad$ R371

RADIATION MONITORING R335

RADIATION PROTECTION R334

RADIATION SHIELDING R333

RADWASTE MINIMIZATION R378, 387, 389

RADWASTE SYSTEM R341

REACTOR MATERIAL R334, 336

REACTOR PRESSURE VESSEL R342

RESIN OXIDATION R389

RETUBING R350

ROTATING CYLINDER ELECTRODE R355

SHUTDOWN CHEMISTRY R362, 384

SOLUBILITY R363

STAINLESS STEEL R342-343, 356, 374, 385

STEAM GENERATOR R336, 371

STELLITE R374

STELLITE $6 \quad$ R398

STRESS CORROSION CRACKING R356, $359,366,370,376,380,390$ 
STRIPPING VOLTAMMETRY R347 SUB-SYSTEM DECONTAMINATION R377

SURFACE CONDITIONING R385, 403

SURFACE PREPARATION R385 SURFACE PRETREATMENT R403 SURFACE TREATMENT R385 ULTRAVIOLET RADIATION R341 VALVE R337-338 WASTE FILTRATION R367
WASTE VOLUME REDUCTION R378, 389

WATER CHEMISTRY R334, 344, 357-360, 362, 370-371, 375, 380-383, 386, $395,400-401$

WATER QUALITY R341

WEAR-RESISTANT ALLOY R399

ZINC R356, 400

ZINC ADDITION R348, 388, 40i-401

ZINC INJECTION R386

ZIRCALOY R340, 383 


\section{BNL ALARA Center Data Base}

\section{BWR UNDERWATER DISASSEMBLY/ASSEMBLY - WETLIFT 2000}

Keywords: CONTAMINATION PREVENTION; RADIATION SHIELDING; REMOTE SYSTEMS; EXPOSURE REDUCTION

\section{Principal Investigator:}

Peter Wivagg

ABB Combustion Engineering

1000 Prospect Hill Road

P.O. Box 500

Windsor, CT 06095-0500

U.S.A.

Phone: 203-285-9556
Project Manager:

Bengt Baversten

ABB Combustion Engineering

100 i Prospect Hill Road

P.O. Box 500

Windsor, CT 06095-0500

U.S.A.

Phone: 203-285-6802

Objectives: Primary objectives are: to conduct BWR disassembly and assembly operations under water; to reduce contamination and exposure; to speed operations by using remote tooling technology; to improve personnel safety; and to reduce cavity and equipment pool entries.

Other objectives are to reduce critical path time; to reduce exposure; to improve personnel safety; to reduce person-hours; to ease decontamination; and to accomplish this with no physical modifications to existing plant equipment.

Comments: The WETLIFT 2000 system has been used at GPU's Oyster Creek Nuclear Generating Station and allows:

- Reactor cavity flooding immediately after head removal.

- Steam dryer and separator transfer underwater with only one reactor cavity flooding.

- Latching and unlatching of the dryer and separator from refueling bridge.

- Steam plug insertion and withdrawal from refueling bridge.

- Watertight seal of equipment pool shield plugs during reactor vessel maintenance. WETLIFT 2000 System consists of four major component parts: dryer/separator sling, rigid pole-handling system, steam line plug tooling, and watertight gate system.

Except for the watertight seal, the WETLIFT 2000 system has also been used at CECO's LaSalle County Station.

Remarks/Potential for dose limitation: The principal benefits of the system are:

- Critical Path Reduction

- One cavity flooding for reactor disassembly and assembly

- All operations performed from refueling bridge

- Remote separator, dryer and shield plug hookup and disconnect

- Accurate positioning, insertion \& withdrawal of steam line plugs 


\section{BNL ALARA Center Data Base}

SWEDEN/U.S.A.

Remote latching and unlatching of dryer hold downs \& shroud head bolts

- No shield plug leakage cleanup Exposure Reduction

- Cavity flooding immediately after head removal

- No cavity work for dryer, separator and steam plug manipulations

- Dryes' and separator remain underwater

- Equipment designed for quick decontamination

- Latching and unlatching of dryer hold down and shroud head bolts from refueling bridge

- Steam plug insertion and withdrawal from the refueling bridge

- Significant reduction in respirator and PC work

- Reduced cavity and storage pool entries

- Hook and block stay DRV and contamination-free.

\section{References:}

Duration: from: 1990 to: 1992

Funding: N/A

Status: Complete

Last Update: May 27, 1992 
PWR PRIMARY SYSTEM CHEMISTRY: EXPERIENCE WITH ELEVATED PH AT MILLSTONE POINT UNIT 3

Keywords: OPERATIONAL. AND MAINTENANCE TECHNIQUES; RADIATION PROTECTION; REACTOR MATERIAL; WATER CHEMISTRY; FUEL

\section{Principal Investigator:}

Carl Bergmann

Westinghouse Electric Corporation

P.O. Box 355

Pittsburgh, PA 15 30

U.S.A.

Phone: $412 / 3745166$

\author{
Project Manager: \\ Howard Ocken \\ Electric Power Research Institute \\ P.O. Box 10412 \\ Palo Alto, CA 10412 \\ U.S.A.
}

Phone: 415/855 2055

Objectives: Earlier EPRI m'easurements of the solubility of simulated fuel crud, together with modeling of crud transport phenomena, led to the conclusion that a $\mathrm{pH}$ of 74 was superior to a $\mathrm{pH}$ of 6.9 for minimizing buildup of radiation fields. Operation of the Ringhals PWRs in Sweden and an earlier cycie of operation at Millstone-3 showed the benefit of operating at higher $\mathrm{pH}$. However, additional data were deemed ne':essary to determine the effects of long-term operation at higher lithium hydroxide concentrations on the performance of plant components, especially Zircaloy-clad fuel rods.

The objectives are

1. To measure dose rates after operating for one fuel cycle to a terminal $\mathrm{pH}$ of 7.2 (following operation for one fuel cycle to a terminal $\mathrm{pH}$ of 7.4) and compare these values with other pertinent dose-rate data, and

2. To measure Zircaloy cladding oxide thickness and compare it with similar data obtained from the North Anna PWR.

Comments: Plant chemistry staff maintained the lithium concentration at $3.35 \pm 0.15 \mathrm{ppm}$ until the $\mathrm{pH}$ reached 7.2 ; the $\mathrm{pH}$ was then held constant until the end of the cycle. The project team then used visual examinations and an eddy current nondestructive evaluation technique to assess oxide buildup on selected fuel rods. Other tasks included dose-rate measurement at standard piping and steam generator locations as well as gamma spectrometry to determine radionuclide concentrations. Dose-rate measurement trends were analyzed using the contractor's CORA code. The beneficial effects of elevated $\mathrm{pH}$ operation on radiation fields at Millstone-3 persisted for a second cycle, even though the $\mathrm{pH}$ was held at 7.2, rather than the 7.4 value used in the previous cycle. This change halved the time that the unit operated at 3.35 ppm lithium. Operation with elevated lithium appeared to increase Zircaloy cladding corrosion, but the effects are impossible to quantify, given the extensive scatter in the data. Because of the anticipated length of the next fuel cycle, the utility decided to continue operating at a constant $\mathrm{pH}$ of 6.9 to minimize the exposure time with lithium concentrations greater than $2.2 \mathrm{ppm}$. 


\section{BNL ALARA Center Data Base}

U.S.A.

R-334

Remarks/Potential for dose limitation: The use of elevated $\mathrm{pH}$ for a second cycle of operation of the Millstone Point unit 3 PWR continued to reduce radiation-field buildup rates significantly. Dose rates were about $15 \%$ lower than in plants operating under coordinated chemistry.

Comparison of the Millstone-3 oxide thickness data and the North Anna high-burnup oxide thickness data suggests that operation with elevated lithium may increase the corrosion rate of Zircaloy cladding. However, the large variation in oxide thickness measurements prevents one from drawing any firm conclusions. Higher $\mathrm{pH}$ operation had no observable effect on any other fuel-assembly components. Observed and CORA-calculated dose rates measured here and at the Swedish Ringhals-3 PWR are consistent. Component dose rates are about 15\% lower for elevated coolant $\mathrm{pH}$ operation compared with operation under coordinated chemistry at a pH of 6.9 .

\section{References:}

1. EPRI NP-7077, PWR Primary Water Chemistry Guidelines, Revision 2.

2. EPRI TR-100960, PWR Primary System Chemistry: Experience with Elevated $\mathrm{pH}$ at Millstone Point Unit 3, Progress Report Number 2, July 1992, 140 pages.

Duration: from: 1990 to: 1994

Funding: N/A

Status: Continuing

Last Update: October 28, 1992 


\section{STEAM GENERATOR DOSE RATES AT BABCOCK \& WILCOX REACTORS}

\section{Keywords: OPERATIONAL AND MAINTENANCE TECHNIQUES; RADIATION MONITORING; RADIATION DOSE}

\section{Principal Investigator:}

Babcock and Wilcox

Nuclear Services Company

P.O. Box 10935

Lynchburg, VA 24506

U.S.A.

Phone: 804-847 3314

\author{
Project Manager: \\ Mr. Howard Ocken \\ Electric Power Research Institute \\ P.O. Box 10412 \\ Palo Alto, CA 94303 \\ U.S.A. \\ Phone: 415-855 2055
}

Objectives: EPRI has long supported radiation field measurements at operating reactors designed by the different nuclear steam supply vendors. These data are useful in determining trends at an individual plant, in providing data for interplant comparisons, and in evaluating the effectiveness of various radiation control measures.

The objectives are

1. To collect and compare dose-rate data from seven Babcock and Wilcox reactors at five utilities, and

2. To use the data to analyze the effectiveness of various dose-reduction measures implemented at different units.

Comments: Investigators gathered dose-rate data from five sites in mid-1991. The team collected measurements from surveys performed by utility or contractor personnel during plant outages. Researchers then correlated these data with plant design features, operating features, and dose-reduction measures used at each plant. Specific areas addressed in the study included cobalt reduction programs, the cobalt content of steam generator tubing, the use of Zircaloy grid spacers in reload fuel, the number of crud bursts, hydrogen peroxide flushing, primary coolant chemistry, decontamination, and the use of microfiltration.

Remarks/Potential for dose limitation: At the seven units reviewed, upper channel head contact dose rates ranged between 6 and $21 \mathrm{R} / \mathrm{hr}$, while lower channel head contact dose rates ranged between 4 and $20 \mathrm{R} / \mathrm{hr}$. The two most effective techniques in reducing dose rates at these units have been the use of Zircaloy grid spacers in reload fuel and the use of elevated $\mathrm{Li} / \mathrm{pH}$ primary coolant chemistry. This information should prove valuable to utility personnel assigned the responsibility for reducing occupational radiation exposure of maintenance personnel.

References: EPRI TR-100348, Final Report, July 1992, 64 pages.

Duration: from: 1990 to: 1994

Status: Continuing

\section{Funding: N/A}

Last Update: October 28, 1992 


\section{BNL ALARA Center Data Base}

U.S.A.

\section{PRECONDITIONING OF PWR STEAM GENERATORS TO REDUCE RADIATION BUILDUP}

\section{Keywords: CONTAMINATION PREVENTION; STEAM GENERATOR; RADIATION BUILDUP; REACTOR MATERIAL; INCONEL}

\section{Principal Investigator:}

Commissariat L'Energie Atomique FRANCE

\author{
Project Manager: \\ Christopher Wood \\ Electric Power Research Institute \\ 3412 Hillview Avenue \\ P.O. Box 10412 \\ Palo Alto, CA 9430 U.S.A. \\ Phone: 415/855 2379
}

Objectives: Examine potential passivation (preconditioning) techniques to determine which form the most stable oxides on alloys used in PWR replacement steam generators, thus reducing corrosion-product rates to the primary coolant.

Comments: Inconel 600 and Inconel 690, the most common steam generator tubing alloys, were chosen for the study along with type 316 stainless steel. Samples were preoxidized under a variety of conditions thought to form adherent, stable oxides. They were then activated and placed in an experimental water-circulating loop. The test facility simulates PWR primary conditions within well-controlled chemistry limits. On-line instrumentation, filters, and resin (ion-exchange) columns collected corrosion products or detected their movement as a function of running time and other key parameters.

Study results were disappointing. At the start of the tests, corrosion release rates differed for samples preoxidized under different conditions. But after 2,000 hours, release rates were reduced, and there were no discernible differences among samples. Preoxidized specimens released more corrosion products than those tested in the unpassivated condition, indicating that reducing conditions should be used. In all cases with Inconel 690, release rates were lowest at $\mathrm{pH}$ 7.2-7.4

Remarks/Potential for dose limitation: This study relates only to release of corrosion products, and its results apply only to PWR chemistry. Studies of the effects of preoxidation on deposition of activated corrosion products are described in EPRI reports NP-6616 and TR-100059. Prefilming replacement components for BWRs is more beneficial because deposition is reduced under oxidizing chemistry.

The results do support experience in other countries showing that for PWR startups -which include hot functional tests and the presence of normal reactor coolant chemicals ( $\mathrm{LiOH}$ and boric acid) -- the coolant must be deaerated and hydrogen added as early as possible.

References: EPRI TR-100217, Final Report, August 1992, 60 pages.

Duration: from: 1991 to: 1992 Funding: N/A

Status: Completed Last Update: October 28, 1992 
WELDING OF NOREM IRON-BASE HARDFACING ALLOY WIRE PRODUCTS - PROCEDURES FOR GAS TUNGSTEN ARC WELDING

\author{
Keywords: COMPONENT RELIABILITY; IRON-BASE ALLOY; COBALT; \\ NOREM; HARDFACING ALLOY; VALVE
}

\section{Principal Investigator:}

Michael Phillips

EPRI NDE Center

1300 Harris Blvd.

Charlotte, NC 28262

U.S.A.

Phone: 704-547-6082

\author{
Project Manager: \\ Howard Ocken \\ Electric Power Research Institute \\ P.O. Box 10412 \\ Palo Alto, CA 94303 \\ U.S.A.
}

Phone: 415-855 2055

Objectives: Cobalt-base hardfacing alloys used in valves and other critical components in nuclear reactors are a significant contributor to radiation field buildup and to the occupational radiation exposure of plant maintenance personnel. Laboratory studies, described in EPRI report NP-6466-SD, show that NOREM iron-base alloys exhibit wear properties matching those of cobalt-base alloys. However, wire products and welding procedures were needed for field applications.

The objectives of this project are:

- To secure metal core and homogenous weld wire of NOREM alloys suitable for deposition by automatic gas tungsten arc welding (GTAW).

- To develop welding procedures for these wire products.

- To measure the galling wear resistance of specimens prepared using EPRI's newly developed welding procedures.

Comments: Researchers obtained metal-core and homogeneous NOREM weld wire from a number of sources that relied on standard commercial practices in fabricating the product. They next used GTAW to deposit the wire on carbon and stainless steel plate and piping as well as on residual strips of cobalt-base alloy. Finally, they deposited the wire on pins and plates specially made for galling wear tests.

Researchers successfully used GTAW to deposit sound weld overlays of NOREM wire products on Type 304 stainless steel and SA-515 carbon steel substrates without any preheating. The NOREM alloy can also be deposited over a continuous or intermittent layer of cobalt-base Stellite 21 previously deposited by plasma arc welding (PTAW). Wire products with lower $\mathrm{Mn}$ and $\mathrm{Si}$ contents than used in gas atomized powder exhibited the best results. Wire cleanliness also proved a critical factor in achieving sound welds. In wear testing, NOREM PTAW overlays were as resistant to galling as specimens prepared using Stellite 21 .

Remarks/Potential for dose limitation: Laboratory studies reported in EPRI report NP-6466-SD showed that the wear resistance of NOREM iron-base alloys matched that of cobalt-base alloys and possessed other properties required of hardfacing alloys. PTAW of gas 


\section{BNL ALARA Center Data Base}

U.S.A.

atomized powder was used to successfully deposit these alloys on 3-inch valves, which were then subjected to long-term endurance tests under simulated PWR chemistry conditions. Extensive nondestructive and destructive evaluations showed that these valves performed better than one with Stellite 6 trim (report TR-100601). Similar valve tests are now being completed under BWR chemistry conditions. The need for field hardfacing replacements and repairs led to this NOREM wire development and welding evaluation program for in-situ applications. The study demonstrated that the NOREM alloy can be fabricated using standard hardfacing wire production practices and deposited successfully on stainless and carbon steel substrates by automatic GTAW. The NOREM alloy is weldable and exhibits wear and resistance equivalent to or better than cobalt-base alloys. Overall, NOREM alloys should be considered for field applications in both nuclear and fossil plant valves.

\section{References:}

1. EPRI NP-6466-SD.

2. EPRI Report TR-101094s

3. EPRI Report TR-100601

Duration: from: 1990 to: 1994

Status: Continuing

Funding: N/A

Last Update: November 17, 1992 


\section{ENDURANCE TESTS OF VALVES WITH COBALT-FREE HARDFACING ALLOYS}

\section{Keywords: CONTAMINATION PREVENTION; COBALT; IRON; VALVE; HARDFACING ALLOY; DOSE REDUCTION; RADIATION BUILDUP; ALLOY}

\section{Principal Investigator:}

E.V. Murphy

Atomic Energy of Canada Limited

Sheridan Park Research Community

Mississanga, Ontario L5K 1B2

CANADA

Phone:

\author{
Project Manager: \\ Howard Ocken \\ Electric Power Research Institute \\ P.O. Box 10412 \\ Palo Alto, CA 94303 \\ U.S.A.
}

Phone: 415-855-2055

Objectives: To develop weld procedures for the candidate alloys on 3-in. gate valves. To determine if the iron-based hardfacing alloys have wear properties matching those of cobalt-based alloys under simulated BWR conditions.

Comments: The performance of the alloys was assessed as follows:

- A number of diverse techniques were employed, including metallography, chemical analysis, hardness, and dye penetration tests

- The iron-based alloys used were NOREM, EB 5183, and EVERIT 50.

- The cobalt-based alloy Stellite 6 was used as a standard.

- The valves were operated under simulated normal BWR primary coolant chemistry conditions ( $200 \mathrm{ppb}$ oxygen) for 970 full-stroke cycles.

After the first 506 cycles, the valves were characterized by using nondestructive examination techniques: visual ex:minations, leak rate measurements, and profilometry. After 970 cycles, these examinations were complemented by detailed metallurgical characterization of the valve trim.

Remarks/Potential for dose limitation: The results indicate that with the exception of EB 5183, which is susceptible to pitting attacks, the corrosion resistance of the iron-based alloys is equal or superior to that of Stellite 6. Cobalt-based hardfacing alloys are used in valves and other critical components in nuclear reactors. They are a significant contributor to radiation-field buildup and occupational exposure to plant maintenance personnel. Using cobalt-free alloys to replace or refurbish valves will significantly reduce released cobalt.

References: "Endurance Testing of Valves With Cobalt-Free Hardfacing Alloys," EPRI-TR-101847, Final Report, January 1993.

Duration: from: 1991 to: 1993

Status: Completed
Funding: N/A

Last Update: May 28, 1993 


\section{REPLACEMENT OF PINS AND ROLLERS IN IRRADIATED BWR CONTROL BLADES}

Keywords: CONTAMINATION REMOVAL; CONTAMINATION PREVENTION; REMOTE SYSTEM; COBALT; CONTROL BLADE; RADIATION FIELD

\section{Principal Investigator:}

Norman Stolzenberg

ABB Combustion Engineering

1000 Prospect Hill Road

Windsor, CT 06095

U.S.A.

Phone: 203-285-5405

\author{
Project Manager: \\ Howard Ocken \\ Electric Power Research Institute \\ 3412 Hillview Ave., P.O. Box 10412 \\ Palo Alto, CA 94303 \\ U.S.A.
}

Phone: (415)855-2055

Objectives: To design, fabricate, and demonstrate remotely operated equipment that could be used in the spent-fuel pool at BWR sites and would remove the upper pins and rollers in irradiated control blades, replacing them with stainless steel buttons.

Comments: The equipment uses electrical discharge machining (EDM) to remove the uppe: roller, most of the pin, and a small portion of the control blade. All cut material is collected in a waste container, and fine dust from the EDM operation is collected on a filter. The cut surface is brushed, finished, and inspected. Two stainless steel button halves are remotely riveted together, and their installation is checked with a torque test. The equipment was designed and tested on unirradiated control blades. Modifications were made to accommodate various control blade designs, and the system was then tested at Commonwealth Edison's LaSalle Station.

Remarks/Potential for dose limitation: The equipment was successfully set up and demonstrated at the LaSalle Station. However, work was limited to one wing of one blade due to high dose readings on the filters used to collect radioactive cobalt dust from the EDM operation. These readings would not present a problem if the filters were placed in high-integrity containers. The cobalt-based alloys used in the pins and rollers of BWR control blades are a significant source of the released cobalt that contributes to occupational radiation exposure. Remotely operated equipment permits replacement of the radioactive upper pins and rollers in control blades in the spent-fuel pool.

References: "Replacement of Pins and Rollers in Irradiated BWR Control Blades," EPRI-TR-101837 Vol. 1, Final Report, February 1993.
Duration: from: 1991 to: 1993
Funding: N/A

Status: Completed

Last Update: September 3, 1993 


\section{SECONDARY HYDRIDING OF DEFECTED ZIRCALOY-CLAD FUEL RODS}

Keywords: COMPONENT RELIABILITY; CONTAMINATIC:" PREVENTION; HYDROGEN; ZIRCALOY; CORROSION; FUEL ROD CLADDING

\section{Principal Investigator:}

University of California, Berkeley

\author{
Project Manager: \\ Suresh Yagnik \\ Electric Power Research Institute \\ 3412 Hillview Ave. \\ P.O. Box 10412 \\ Palo Alto, CA 94303 \\ U.S.A.
}

Phone: 415-855-2411

Objectives: To examine the secondary hydriding of Zircaloy cladding in a breached LWR fuel rod and evaluate its role in the fuel rod degradation process.

Comments: This study began with a literature review to summarize the current status and understanding of processes pertinent to breached cladding. Analysis of these processes led to initial governing equations, which when solved, enable investigators to determine the location at which secondary hydriding can occur in a fuel rod.

- The source of steam in secondary hydriding is the flashing of coolant through the primary defect. However, the fuel pellets are unlikely to be oxidized by the steam at prevailing temperatures.

- Fission fragments can generate substantial quantities of reactive species such as hydrogen peroxide, which are quite capable of oxidizing the f. l pellets. Such oxidation is a potentially larger source of hydrogen that can cause secondary hydriding in the cladding.

Remarks/Potential for dose limitation: It was shown that a primary defect in the Zircaloy cladding can lead to conditions that may cause secondary hydriding of the cladding. The cladding may subsequently become hydrogen-embrittled, or local massive hydride regions may form. In either case, a rupture in the cladding is possible, often far removed from the primary defect location. Thus, a small through-wall breach in the Zircaloy cladding of an LWR fuel rod can lead to a rapid degradation of the fuel rod. This causes a large quantity of radioactivity to be released into the primary coolant system.

References: "Secondary Hydriding of Defected Zircaloy-Clad Fuel Rods," EPRI TR-101773, Final Report, January 1993.

Duration: from: 19 to: 1993 Funding: N/A

Status: Completed Last Update: May 28, 1993 


\section{TESTING OF AN ORGANIC REMOVAL PROCESS IN BWR RADWASTE SYSTEMS}

Keywords: CONTAMINATION PREVENTION; CORROSION; ORGANIC SUBSTANCES; WATER QUALITY; OZONE; ULTRAVIOLET RADIATION; RADWASTE SYSTEM

Principal Investigator:

Robert Head

GE Nuclear Energy

195 Curtner Ave. MC 783

San Jose, CA 95125

U.S.A.

Phone: 408-925-6556

\author{
Project Manager: \\ T. Passell \\ Electric Power Research Institute \\ 3412 Hillview Ave., P.O. Box 10412 \\ Palo Alto, CA 94303 \\ U.S.A.
}

Phone: 415-855-2070

Objectives: Naturally occurring organic plus lubricating oils and cleaning solvents are present in plant water systems. These compounds are not removed by the usual plant purification systems. A process based on ozone-ultraviolet radiation has been demonstrated to be capable of degrading and removing organics. The objectives of the study are:

- To optimize the ozone-ultraviolet treatment system parameters.

- To evaluate the effect of residual ozone on ion-exchange resins.

- To determine the reaction time required to effectively treat organic transients.

- To evaluate the efficiency of the process for removal of organics in both high- and low-purity wastes.

- To quantify the expected reduction in radwaste ion-exchange resin usage resulting from reduced organic concentration.

\section{Comments:}

- Pilot-scale tests were carried out at Vallecitos Nuclear Center followed by tests on radwaste systems at Dresden and Susquehanna.

- Process streams containing common organic contaminants were introduced into a vessel outfitted with ultraviolet lamps.

- Oxygen and ozone were fed continuously into the vessel.

- Oxidation of the organic was monitored as a function of time, and downstream ozone concentration was also measured.

The treatment system parameters were optimized as follows:

- 100 ppm ozone in combination with ultraviolet light oxidized $90 \%$ of the organic in 15-30 min.

- Ion-exchange resins helped remove the oxidized ions of organic acids, nitrates, and sulfates.

- In simulated organic transients or spills, $300 \mathrm{ppm}$ ozone oxidized $>90 \%$ of organic compounds even in turbid waters in times of up to $60 \mathrm{~min}$. 


\section{BNL ALARA Center Data Base}

U.S.A.

R-341

- Electrohydraulic control fuel was efficiently removed, nonreactive silica was converted to a removable, reactive form.

- Essentially no ozone was detected in the effluent of the process, and there was no damage to the downstream resins.

Remarks/Potential for dose limitation: In reactor water, thermal decomposition and oxidation of organics may yield corrosive species such as acids. The development of a method for their removal reduces the danger to components and relieves the burden on plant purification systems. The operating savings in exposure and funds from this process are sufficient for utilities to consider a full-scale installation. At Susquehanna, the ozone treatment would reduce the liquid waste discharge by $50 \%$ and the resin usage by $65 \%$, thereby decreasing operating costs.

References: "Testing of an Organic Removal Process in BWR Radwaste Systems," EPRI NP-7195, Final Report, February 1993.

Duration: from: 1988 to: 1991

Funding: N/A

Status: Completed

Last Update: September 3, 1993 


\section{EVALUATION OF REACTOR PRESSURE VESSEL HEAD CRACKING IN TWO DOMESTIC BWRS}

\section{Keywords: COMPONENT RELIABILITY; REACTOR PRESSURE VESSEL; IGSCC; STAINLESS STEEL; LOW-ALLOY STEEL}

\section{Principal Investigator:}

Structural Integrity Associates

\section{Project Manager:}

R. Pathania

Electric Power Research Institute 3412 Hillview Ave., P.O. Box 10412 Palo Alto, CA 94303

U.S.A.

Phone: 415-855-2411

Objectives:

1) Determine the cause of cracking in the reactor pressure vessel (RPV) top head at two domestic BWRs

2) use structural analysis methods for assessing the consequences of cracking on continued top head operation

Comments: Two BWRs, Quad Cities unit 1 and Vermont Yankee, experienced cracking in the stainless steel cladding of the RPV top head. The following tests were done at Quad Cities:

- surface penetrant testing (PT)

- ultrasonic testing (UT)

- metallurgical failure analyses

- finite-element analyses

At Vermont Yankee, only visual analysis, PT, and UT were performed. In both cases, structural analyses were done to determine the consequences of cracking on the structural reliability of the RPV head.

Remarks/Potential for dose limitation: The cracking in the austenitic stainless steel cladding was a result of IGSCC. This was caused by the oxidizing nature of the BWR environment, which can be particularly severe in the top head region. The study also showed that cracking in low-alloy steel was not associated with the coolant environment, but rather it resulted from a reheat cracking mechanism that can affect certain low-alloy steels. Structural analyses demonstrated that both plants had considerable structural margin, meeting ASME Code Section XI requirements for continued operation without repair. The vessel head region can be made less susceptible to IGSCC by improved water chemistry controls, and by using hydrogen water chemistry wherever practical.

References: "Evaluation of Reactor Pressure Vessel Head Cracking in Two Domestic BWRs" EPRI TR-101971, Final Report, February 1993.

Duration: from: 1992 to: 1993

Funding: N/A

Status: Completed

Last Update: September 3, 1993 


\section{RELATIONSHIP OF RADIATION-INDUCED SEGREGATION PHENOMENA TO IRRADIATION-ASSISTED STRESS CORROSION CRACKING (IASCC)}

\section{Keywords: COMPONENT RELIABILITY; IASCC; STAINLESS STEEL; ELECTRON MICROSCOPY; NICKEL ALLOY}

\author{
Principal Investigator: \\ Westinghouse Science \\ and Technology Center
}

\author{
Project Manager: \\ J. Nelson \\ Electric Power Research Institute \\ 3412 Hillview Ave., P.O. Box 10412 \\ Palo Alto, CA 94303 \\ U.S.A. \\ Phone: 415-855-2411
}

Objectives: The aim of this study was to enhance the understanding of IASCC in austenitic stainless steels and nickel base alloys by examining microstructural changes and grain boundary segregation as a function of irradiation at LWR temperatures.

Comments: The following alloys were studied:
1) Type 304 stainless steel
3) high-purity Type 304 stainless steel
2) Type 316 stainless steel
4) commercial purity alloy $X-750$

The techniques used for the microstructural examination and the grain segregation studies were scanning transmission electron microscopy (STEM) and auger electron spectroscopy (AES). Each of the four alloys were examined after being irradiated, and nonirradiated specimens served as controls.

Remarks/Potential for dose limitation: The investigations demonstrated that exposure to high neutron fluences at LWR temperatures produces microstructural and grain boundary changes in austenitic stainless steels and nickel base alloys. The STEM studies revealed black spot damage in the Type 316 stainless steel specimens at both high and low fluences. Such damage is responsible for the large increase in yield stress observed in steels irradiated at low temperatures. The AES analysis revealed evidence of chromium depletion at the grain boundaries of the high-purity and commercial-purity Type 304 stainless steel specimens as well as the alloy X-750 specimen. Nickel enrichment occurred in both the high-purity Type 304 and alloy X-750 samples. Some evidence of phosphorus and sulfur segregation was visible in the grain boundaries of the commercial-purity specimens.

References: "Relationship of Radiation-Induced Segregation Phenomena to Irradiation-Assisted Stress Corrosion Cracking (IASCC)," EPRI TR-101987, Final Report, February 1993.

Duration: from: 19 to: 1993 Funding: N/A 


\section{LIGHT WATER REACTOR MATERIALS AND WATER CHEMISTRY STUDIES AT HALDEN}

\section{Keywords: COMPONENT RELIABILITY; WATER CHEMISTRY; PRIMARY COOLANT CHEMISTRY; LITHIUM; IASCC; CORROSION}

\section{Principal Investigator:}

T. Karlsen

OECD Halden Reactor Project

PO Box 173 Halden, N-1751

NORWAY

Phone: +479183100

\author{
Project Manager: \\ P. Gunnerud \\ OECD Halden Reactor Project \\ P O Box 173 Halden, N-1751 \\ NORWAY \\ Phone: +479183100
}

Objectives: The objective of the PWR Test Facility experiments is to determine the effects of high lithium concentrations on the corrosion behavior of Zircaloy-4. The objective of the IASCC facility studies is to assess the effect of water chemistry environment on the cracking propensity of in-core structural materials commonly found in BWRs.

Comments: The Halden Reactor Project test facilities are designed to produce the radiation, thermal hydraulic, and water chemistry conditions representative of those found in commercial Light Water Reactors. The PWR facility is being used to determine the effects of high lithium concentration on the corrosion behavior of high burnup Zircaloy-4 fuel rods. 4-4.5 $\mathrm{ppm}$ lithium and $1000 \mathrm{ppm}$ boron were added to the water. The $\mathrm{pH}$ was $7.2-7.3$ at $300^{\circ} \mathrm{C}$, and after 250 full power days, the boron concentration was reduced to $700 \mathrm{ppm}$ (pH 7.4). Oxide thickness was measured in order to determine the effect of lithium concentrations on corrosion rates. Early results indicate that increased lithium concentrations have little effect on enhancing corrosion rates. The IASCC loop system is designed to operate under both Normal BWR Water Chemistry (NWC) and Hydrogen Water Chemistry (HWC) conditions. In order to determine the benefits of HWC in mitigating crack propagation, the specimens are exposed to NWC with the introduction of HWC at various stages during the course of irradiation. Corrosion potential and solution conductivity are closely monitored.

Remarks/Potential for dose limitation: It is hoped that future investigations at Halden will address the feasibility of applying chemical additives such as zinc to control radiation buildup in PWRs. Further investigations relating to IASCC behavior of structural component materials are also expected.

References: Karlsen, T., Gunnerud, P., and Vitanza, C., "Light Water Reactor Materials and Water Chemistry Studies at Halden," Water Chemistry of Nuclear Reactor Systems 6, Vol. 1, British Nuclear Energy Society, London, 1992.

Duration: from: 1991 to: 1992

Status: In Progress
Funding: N/A

Last Update: June 4, 1993 


\section{PWR IN-PILE LOOP STUDIES IN SUPPORT OF COOLANT CHEMISTRY OPTIMIZATION}

\section{Keywords: COMPONENT RELIABILITY; CONTAMINATION PREVENTION; PRIMARY COOLANT CHEMISTRY; PH; CORROSION CONTROL; RADIATION BUILDUP}

\section{Principal Investigator:}

Michael Driscoll

Massachusetts Institute of Technology

138 Albany St., NW13-259

Cambridge, MA 02139

U.S.A.

Phone: 617-253-4219

\author{
Project Manager: \\ Otto Harling \\ Massachusetts Institute of Technology \\ 138 Albany St., NW13-259 \\ Cambridge, MA 02139 \\ U.S.A.
}

Phone: 617-253-4219

Objectives: The aim of this study is to investigate the effects of primary coolant $\mathrm{pH}$ on corrosion product oxide mass and radionuclide inventories on loop component surfaces.

Comments: A series of three 3000 hour in-pile loop runs are in progress using the MIT PWR Coolant Chemistry Loop (PCCL) to verify the selection of $\mathrm{pH}$ for use in PWR coolant. The following measurements and examinations are made:

- corrosion product oxide mass

- radionuclide inventories

- surface SEM examination before and after crud removal

- waterborne radionuclide concentration

- crud filter assays $\mathrm{pH}$ is optimized through adjustment of relative concentrations if $\mathrm{LiOH}$ and $\mathrm{H}_{3} \mathrm{BO}_{3}$

Remarks/Potential for dose limitation: Essentially, all the work to date supports operation at about $\mathrm{pH}\left(300^{\circ} \mathrm{C}\right)=7.3$. Future tests will study the efficacy of zinc injection for reduction of corrosion product radionuclide buildup.

References: Kohse, G.E., Cabello, E.C., Doboe, L., Driscoll, M.J., and Harling, O.K., "PWR In-Pile Loop Studies in Support of Coolant Chemistry Optimization," Water Chemistry of Nuclear Reactor Systems 6, Vol. 1, British Nuclear Energy Society, London, 1992.

Duration: from: 19 to: 1994

Status: In Progress

\section{Funding: N/A}

Last Update: June 4, 1993 


\section{THE EFFECT OF DISSOLVED OXYGEN IN LITHIATED COOLANT}

Keywords: CONTAMINATION PREVENTION; RADIATION BUILDUP; OXIDE FILM; OXYGEN CONTENT; PRIMARY COOLANT CHEMISTRY

\section{Principal Investigator:}

Heather Allsop

AECL Research

Station 61 AECL

Chalk River, ONTARIO KOJ 1 JO

CANADA

Phone: 613-584-3311 Ext. 3268
Project Manager:

D. Lister

University of New Brunswick

P O Box 4400

Fredericton, NEW BRUNSWICK B3B 5 A3

CANADA

Phone: 506-453-5138

Objectives: The aim of this study was to determine the effect of slightly oxidizing conditions on cobalt-60 activity buildup on 403 stainless steel, carbon steel, and iron oxide pellets. It has been hypothesized that oxidizing conditions lead to a higher rate of field growth.

Comments: Experiments were performed in a high-temperature experimental loop constructed of 304 stainless steel. The measurements and examinations done included:

- average Co-60 activity in the water

- Co-60 pickup by oxide pellets and steel surfaces

- scanning electron microscopy (SEM)

- conversion electron Mössbauer microscopy

- transmission electron microscopy (TEM)

- energy dispersive X-ray (EDX)

- scanning auger microprobe (SAM)

Remarks/Potential for dose limitation: The conclusions of the study were as follows:

- Oxide films formed on steel materials in deoxygenated and slightly oxygenated water were seen to have different structures and different affinities for Co-60.

- Oxide films formed under oxidizing conditions were thinner, but had higher Co-60 activities per unit volume of oxide.

Because of these two properties working against each other, the net result was similar Co-60 activity per unit area of base metal under reducing and oxidizing conditions.

References: Allsop, H.A., Sawicki, J.A., Lister, D.H., and Godin, M.S.L., "The Effect Of Dissolved Oxygen in Lithiated Coolant," Water Chemistry of Nuclear Reactor Systems 6, Vol. 1, pp. 25-32, British Nuclear Energy Society, London, 1992.

Duration: from: 19 to: 1992

Status: Completed
Funding: N/A

Last Update: September 3, 1993 


\section{CHEMISTRY PARAMETERS INFLUENCING THE DOSE RATE BUILD-UP IN BWR PLANTS}

Keywords: CONTAMINATION PREVENTION; RADIATION BUILDUP; PRIMARY COOLANT CHEMISTRY; PH; OXYGEN CONTENT; NICKEL; IRON; STRIPPING VOLTAMMETRY; ION CHROMATOGRAPHY

\section{Principal Investigator:}

T.F. Marchl

Siemens AG

Hammerbacherstr $12+14$

D-91058 Erlangen

GERMANY

Phone: +49/9131/18-4074

\section{Project Manager:}

U. Reitzner

Siemens AG

Hammerbacherstr. $12+14$

D-91058 Erlangen

GERMANY

Phone: $+49 / 9131 / 18-2567$

Objectives: The purpose of this paper is to discuss several parameters that are known for influencing the dose rate buildup in BWRs. These factors are related to primary coolant chemistry with certain aspects related to the steam water cycle, including:

- zinc chemistry

- $\mathrm{Ni} / \mathrm{Fe}$ ratio

- oxygen concentration

- $\mathrm{pH}$

\section{Comments:}

- Traces of zinc in the reactor coolant reduce dose rate levels. $\mathrm{Zn}$ addition requires a product depleted in $\mathrm{Zn}-64$ to avoid an increased formation of the activation product $\mathrm{Zn}-65$.

- Co-58 and Co-60 activities on the surface of piping are reduced by the influence of the $\mathrm{Ni} / \mathrm{Fe}$ ratio. However, when increasing the iron concentration too much, the tendency of mobilizing undissolved and activated corrosion products will increase. This is caused by the increased crud deposition on the surfaces of the fuel elements.

- When the oxygen content is too low in medium of the steam water cycle in areas with low alloyed steels, then erosion corrosion of the materials can be increased. This increases the iron input into the RPV, and thus increases the tendency to higher dose rate.

- Increasing oxygen concentration significantly increases material release from cobalt base alloys.

- The use of cobalt reduced materials as hardfacing alloys can contribute highly to the minimization of the dose rate buildup.

- Increasing the pH decreases the metal release rates and mitigates the solubility of corrosion products. Increasing the $\mathrm{pH}$ too far causes the metal release rates and solubilities of corrosion products to increase again. Long term $\mathrm{pH}$ modification in BWRs is an option for the future. 


\section{BNL ALARA Center Data Base}

\section{Remarks/Potential for dose limitation:}

- Filtration, stripping voltametry, and ion chromatography are analytical methods practicable in the necessary low concentration range for monitoring dominating parameters for dose rate buildup and the effect of appropriate countermeasures.

- In general, it seems to be possible to influence the dose rate buildup in a BWR by changing chemical or operational parameters. However, the measures to be taken depend on the specific conditions of the plants and should therefore be determined individually for each plant. It should be considered that the above-mentioned parameters show long term effects, and that measurable results of the dose rate development of the piping will not appear immediately, but the desired effects will be detectable after one or two cycles.

References: Marchl, T.F. and Reitzner, U., "Chemistry Parameters Influencing the Dose Rate Build-Up in BWR Plants," Water Chemistry of Nuclear Reactor Systems 6, British Nuclear Energy Society, London, 1992.

Duration: from: 1985 to: 1992

Status: Completed
Funding: N/A

Last Update: September 3, 1993 


\section{BNL ALARA Center Data Base}

\section{OVERVIEW OF ACTIVITIES FOR THE REDUCTION OF DOSE RATES IN SWISS BOILING WATER REACTORS}

\section{Keywords: CONTAMINATION PREVENTION; PRIMARY COOLANT CHEMISTRY; ZINC ADDITION; COBALT}

Principal Investigator:

H. Alder

Paul Scherrer Institute

Ch-5232 Villigen-PSI

SWITZERLAND

Phone: +41569921 11
Project Manager:

B. Brélaz

Swiss Federal Nuclear Safety Inspectorate Ch-522 . Villigen-HSK

SWITZERLAND

Phone:

Objectives: Two Swiss BWRs, at Leibstadt (KKL) and Mühleberg (KKM) began to add 0.4 $\mathrm{ppb} \mathrm{Zn}$ and $0.65 \mathrm{ppb}$ Fe-III respectively to their feedwater. The aim of this study was to research the following three themes: 1) Statistical analysis of KKL reactor water data, 2) KKL reactor water analysis during the annual shutdown, 3) autoclave tests to clarify the role of water additives on the Co-60 deposition on steel surfaces.

Comments: Statistical water analysis showed that zinc has a moderately reducing effect of the Co- 60 activity in the reactor water. Without $\mathrm{Zn}$ present, Fe has a strong reducing effect, with $\mathrm{Zn}$, a strong increasing effect. $\mathrm{Cr}, \mathrm{Ni}$ also changed sign: without $\mathrm{Zn}$ they have a moderate increasing effect, with $\mathrm{Zn}$, a strong reducing effect.

The reactor water analysis during the annual shutdown in 1991 showed that at $24 \%$ power, the total $\mathrm{Zn}-65$ activity increases by a factor of 8 , mainly because of dissolved $\mathrm{Zn}-65$. At $0 \%$ power, full control rod insertion, the crud particle concentration $>1 \mu \mathrm{m}$ size increases by a factor of 50 . At $160^{\circ} \mathrm{C}, 10 \mathrm{bar}$, an increase in the total Co-60 activity by a factor of 12 is measured.

The laboratory autoclave tests were made with different water additives and austenitic steel samples at simulated BWR conditions. After 6 time periods each of $300 \mathrm{~h}$, the Co-58 buildup (\%) on steel samples exposed to different water additives (ppb) was measured. The results were as follows:

$$
\begin{aligned}
& 20 \mathrm{ppb} \mathrm{Zn} \\
& 107 \text { to } 135 \%
\end{aligned}>\begin{gathered}
\text { Reference } \\
100 \%
\end{gathered}>\begin{gathered}
20 \mathrm{ppb} \mathrm{Fe} \\
64 \text { to } 77 \%
\end{gathered} \quad>\begin{gathered}
1.5 \mathrm{ppb} \mathrm{Zn} \\
47 \text { to } 69 \%
\end{gathered}
$$

Remarks/Potential for dose limitation: In terms of the statistical water analysis, other BWR data sets have to be analyzed in order to determine whether these KKL-specific statements are of general significance. In terms of shutdown observations, it is not yet clear how the plant cooldown procedure should be modified to take these observations into account.

References: Alder, H.P, and Brélaz, P., "Overview Of Activities For the Reduction Of Dose Rates in Swiss Boiling Water Reactors," Water Chemistry of Nuclear Reactor Systems 6, Vol. 1, pp. 45-50, British Nuclear Energy Society, London, 1992.

Duration: from: 1990 to: 1992

Funding: N/A

Status: Completed

Last Update: June 8, 1993 


\title{
OPERATING EXPERIENCE OF JAPANESE IMPROVEMENT AND STANDARDIZATION BWRS AND BEHAVIOR OF
} RADIOACTIVITY IN REACTOR WATER

\author{
Keywords: CONTAMINATION PREVENTION; COBALT; DOSE \\ REDUCTION; PRIMARY COOLANT CHEMISTRY \\ Principal Investigator: \\ K. Ohsumi \\ Hitachi Ltd. \\ Nuclear Power Plant Engineering \\ Hitachi Works \\ Hitachi-shi, 317 \\ JAPAN \\ Phone: 294215384 \\ Project Manager: \\ K. Haraguchi \\ The Tokyo Electric Power Co. Inc. \\ 1-1-3 Uchisaiwai-cho \\ Chiyoda-ku \\ TOKYO 100 \\ JAPAN \\ Phone: +81335018111
}

Objectives: This paper describes the increasing concentration of radioactivity in reactor water at Japanese BWRs and the results of studies to clarify this phenomenon.

Comments: In new Japanese BWRs, increased Co-60 concentrations are occurring which may cause an increase in plant dose rates as operation continues year after year. To suppress such dose rate increases at new plants, the investigators have begun to study the causes of increased Co-60 concentrations. The following possibilities were suggested:

1) dissolution speed of fuel deposits accelerating due to reduced reactivity of Fe and Co

2) dissolution speed of fuel deposits accelerating due to change of oxidized surface conditions of new fuel cladding

3) dissolution speed of fuel deposits increasing due to production of high $\mathrm{Cr}$ content deposits by increased feedwater $\mathrm{Cr}$ concentration

4) highly corrosive fuel spacers

Remarks/Potential for dose limitation: Measures implemented by new plants:

1) use of corrosion-resistant materials for the turbine system

2) dual condensate purification facility

3) oxygen injection into feedwater system

4) use of low-Co materials in feedwater-heater tubes, fuel-spacer springs, and control rod pins and rollers

5) pre-filming

6) $\mathrm{Fe} / \mathrm{Ni}$ ratio control

References: Aizawa, M., Ohsumi, K., Asakura, Y., Morikawa, Y., Hirahara, Y., Sakai, T., and Haraguchi, K., "Operating Experience of Japanese Improvement and Standardization BWRs and Behavior of Radioactivity in Reactor Water," Water Chemistry of Nuclear Reactor Systems 6, Vol. 1, pp. 39-44, British Nuclear Energy Society, London, 1992.
Duration: from: 19
to: 1994
Funding: N/A

Status: In Progress

Last Update: June 8, 1993 


\section{FEEDWATER IRON CRUD REDUCTION FOR CHINSHAN NUCLEAR POWER STATION}

\section{Keywords: CONTAMINATION PREVENTION; IRON; CRUD; RADIATION BUILDUP; FILTRATION; RETUBING}

\section{Principal Investigator:}

T.C. Cheng

1st Nuclear Power Station

P O Box 8, Shihmen, Taipei

TAIWAN, R.O.C.

Phone: 886-2-6383501 Ex. 3423
Project Manager:

T.J. Wen, Associate Scientist

Institute of Nuclear Energy Research

INER AEC P O Box 3-6 Lung-Tang, 32500

TAIWAN, R.O.C.

Phone: 886-3-4711400 Ex. 5314

Objectives: This paper describes the operating history of Chishan Nuclear Power Station and the methods of iron crud identification and reduction used there.

Comments: Chinshan Nuclear Power Station consists of twin 636 megawatt BWRs located about $40 \mathrm{~km}$ north of Taipei. They were put into commercial operation in 1978 and 1979. In 1985, aluminum brass condenser tubing was replaced with titanium tubing. The iron crud concentration subsequently rose from less than $1 \mathrm{ppb}$ to higher than $2 \mathrm{ppb}$. This increase was attributed to the retubing. Crud samples were taken from the condensate pump discharge header, condensate demineralizer influent, common condensate demineralizer effluent, and the feedwater pump outlet. The iron content and other elemental concentration were analyzed using X-Ray diffraction. Crud particle size was determined using scanning electron microscope (SEM) and particle size analyzer.

Remarks/Potential for dose limitation: The investigators concluded that the following improvement measures should be proposed:

- additional prefiltering

- increase the cation to anion volume ratio from $2: 3$ to $1: 1$ or $2: 1$

- decrease the shutdown rate (soft shutdown)

- dry lay up during shutdown period

- recirculation wet lay up

- condenser hot well cleaning

- start up recirculation

- condensate demineralizer performance improvement

- improve backwash procedure

- investigate the height of resin bed

- proper control of dissolved oxygen in feedwater

- material replacement

References: Wen, T.J. et al, "Feedwater Iron Crud Reduction for Chinshan Nuclear Power Station," Water Chemistry of Nuclear Reactor Systems 6, Vol. 1, pp. 57-62, British Nuclear Energy Society, London, 1992.

Duration: from: 1991 to: 1992 Funding: N/A

Status: Completed Last Update: September 3, 1993 


\title{
REACTIONS OF IRON CRUD WITH METALLIC IONS UNDER BWR WATER CONDITIONS
}

\author{
Keywords: CONTAMINATION PREVENTION; OXIDE FILM; ION \\ Principal Investigator: \\ S. Uchida \\ Hitachi Ltd, 3rd Dep. \\ Energy Res Lab \\ 1168 Moriyama-cho \\ Hitachi-shi, IBARAKI-KEN 316 \\ JAPAN \\ Phone: 0294533111 \\ Project Manager: \\ Y. Nishino \\ Hitachi Ltd, 3rd Dep. \\ Energy Res Lab \\ 1168 Mriyama-cho \\ Hitachi-shi, IBARAKI-KEN 316 \\ JAPAN \\ Phone:
}

Objectives: Formation mechanisms and formation rates of $\mathrm{NiFe}_{2} \mathrm{O}_{4}$ and $\mathrm{CoFe}_{2} \mathrm{O}_{4}$ from amorphous $\mathrm{Fe}$ (III) hydroxide and $\alpha-\mathrm{Fe}_{2} \mathrm{O}_{3}$, with $\mathrm{Ni}(\mathrm{II})$ and $\mathrm{Co}$ (II) ions, were studied experimentally to clarify the formation of spinel oxide on BWR fuel rod surfaces.

Comments: The reactions of the amorphous $\mathrm{Fe}(\mathrm{III})$ hydroxide with $\mathrm{Ni}(\mathrm{II})$ and $\mathrm{Co}$ (II) could be explained by a reaction model incorporating two phenomena: the dehydration of $\mathrm{Fe}$ (III) hydroxide, and the diffusion of ions into it. Cobalt (II) ions diffused into $\alpha-\mathrm{Fe}_{2} \mathrm{O}_{3}$ to form $\mathrm{CoFe}_{2} \mathrm{O}_{4}$. Apparent activation energy for $\mathrm{Co}$ (II) diffusion into a $\alpha-\mathrm{Fe}_{2} \mathrm{O}_{3}$ was obtained as 2.72-e5 J/mol. Formation of $\mathrm{NiFe}_{2} \mathrm{O}_{4}$ from $\alpha-\mathrm{Fe}_{2} \mathrm{O}_{3}$ and $\mathrm{Ni}$ (II) was promoted by crystallization of $\mathrm{Ni}(\mathrm{II})$ and $\mathrm{Fe}(\mathrm{III})$ ions from dissolved $\alpha-\mathrm{Fe}_{2} \mathrm{O}_{3}$ and $\mathrm{NiO}$. The apparent activation energy for the nucleation of $\mathrm{NiFe}_{2} \mathrm{O}_{4}$ crystal was obtained as $6.38-\mathrm{e} 5 \mathrm{~J} / \mathrm{mol}$. When $\mathrm{Co}(\mathrm{OH})_{2}$ coexisted with $\mathrm{Ni}(\mathrm{OH})_{2}$ and $\alpha-\mathrm{Fe}_{2} \mathrm{O}_{3}, \mathrm{Co}_{3} \mathrm{O}_{4}$ which has a spinel structure was formed and those particles became nuclei for $\mathrm{NiFe}_{2} \mathrm{O}_{4}$. This lowered the activation energy for the nucleation.

Remarks/Potential for dose limitation: The behavior of metallic ions ( $\mathrm{Ni}, \mathrm{Co}, \mathrm{etc}$ ) and Fe crud (Fe(III) hydroxides and oxides) which enter the primary water by corrosion of structural materials is closely related to radioactivity in the reactor water. Most of these impurities are deposited on the fuel cladding surface in the reactor water where they become activated through neutron irradiation and represent a major source of radioactivity. Boiling on the fuel rod surface accelerates the deposition of Fe crud and ions. It is desirable to suppress the amounts of parent nuclides flowing into the reactor. Then main radioactive species are Co-58 and Co-60, which are produced by the reactions $\mathrm{Ni}-58(n, p) \mathrm{Co}-58$ and Co-59(n, $\gamma)$ Co- 60 respectively. The amount of $\mathrm{Co}$ can be reduced by using low Co content materials. However, reduction of the Ni amount is difficult due to dissolution from $\mathrm{Ni}$ based alloy in the reactor. Then, it is important to change the chemical form of the deposits into spinel oxides $\left(\mathrm{NiFe}_{2} \mathrm{O}_{4} \mathrm{CoFe}_{2} \mathrm{O}_{4}\right.$ etc.), which have lower solubility than mono-oxides ( $\mathrm{NiO}$, $\mathrm{CoO}$, etc.). When spinel oxides form on the fuel rod surface, the release of radioactive species from them is depressed and those concentrations in the reactor water can be kept low. 


\section{BNL ALARA Center Data Base}

JAPAN

R-351

References: Nishino, Y. et al, "Reactions of Iron Crud With Metallic Ions Under BWR Water Conditions," Water Chemistry of Nuclear Reactor Systems 6, Vol. 1, pp. 63-68, British Nuclear Energy Society, London, 1992.

Duration: from: 19 to: 1992

Funding: N/A

Status: Completed

Last Update: June 9, 1993 


\title{
DECOMPOSITION OF HYDROGEN PEROXIDE IN BWR COOLANT CIRCUIT
}

\section{Keywords: CONTAMINATION PREVENTION; PRIMARY COOLANT CHEMISTRY; HYDROGEN PEROXIDE; CORROSION}

\section{Principal Investigator:}

C. Lin

\author{
Project Manager:
}

GE Nuclear Energy

PO Box 460

Pleasanton, CA 94566

U.S.A.

Phone: $510-862-4566$

Objectives: In a BWR primary coolant circuit, the coolant flow velocities and volume-to-surface ratios at various locations are taken into account for the estimation of the decomposition rate of hydrogen peroxide in the system. The decomposition half-times are estimated ranging from a few seconds in the core region to a few minutes in the recirculation piping system.

Comments: Although hydrogen peroxide is believed to exist in the coolant at approximately $280^{\circ} \mathrm{C}$ during power operation, the measurements has not been successful due mostly to surface catalytic effects in the sample line. Thus the actual level of hydrogen peroxide in an operating BWR is still not accurately known. The rate of a heterogeneous catalyzed reaction is dependent upon both mass transfer and chemical activation processes. In a recent laboratory study of hydrogen peroxide decomposition in aqueous solutions, it has been observed that at temperatures lower than $\sim 200^{\circ} \mathrm{C}$, the decomposition reaction is mostly activation-controlled, and above $\sim 200^{\circ} \mathrm{C}$ the mass transfer process becomes an important factor in determining the overall reaction rate.

Remarks/Potential for dose limitation: By combining the above results and the laboratory test results for the activation-controlled rate constants extrapolated to $280^{\circ} \mathrm{C}$, the overall rate constants at various locations in a BWR primary coolant circuit have been calculated. The decomposition half-times are estimated ranging from a few seconds in the core region to a few minutes in the recirculation piping system. Hydrogen peroxide is one of the stable products radiolytically produced in BWR coolant. Understanding the chemical properties of hydrogen peroxide in the BWR coolant has become an important factor in dealing with the material corrosion problems in the BWR primary system.

References: Lin, C.C., "Decomposition of Hydrogen Peroxide in BWR Coolant Circuit," Water Chemistry of Nuclear Reactor Systems 6, Vol. 1, pp. 85-88, British Nuclear Energy Society, London, 1992.

Duration: from: 1989 to: 1992

Funding: N/A

Status: Completed

Last Update: September 3, 1993 


\title{
FULL PRIMARY SYSTEM CHEMICAL DECONTAMINATION QUALIFICATION PROGRAM
}

\author{
Keywords: CONTAMINATION REMOVAL; CAN-DEREM; LOMI; \\ DECONTAMINATION; FULL SYSTEM DECONTAMINATION

\section{Principal Investigator:} \\ P. Miller \\ Westinghouse Nuclear and Advanced \\ Technology Division \\ P O Box 355 ECE-511A \\ Pittsburgh, PA 15230 \\ U.S.A. \\ Phone: 412-374-6111 \\ Project Manager: \\ H. Ocken \\ Electric Power Research Institute \\ P O Box 10412 \\ Palo Alto, CA 94303 \\ U.S.A. \\ Phone: 415-855-2055
}

Objectives: Determine the technical acceptability of using certain dilute chem:ral solvent processes for full reactor coolant system (RCS) chemical decontamination. Two processes, CAN-DEREM and LOMI, were selected as candidates to be qualified for use in a PWR.

Comments: The study of the two decontamination methods was divided into seven tasks:

1. Process Qualification Test Program

2. Fluid Systems Evaluation of Decontamination Process Integration With RCS and Auxiliary Systems

3. Engineering Evaluation of RCS Components and Systems

4. Waste Management Methodology and Waste Characteristics

5. Evaluation of Long-Term Benefit of Full RCS Decontamination

6. Preparation of Topical Report and Generic Safety Evaluation

7. Full RCS Decontamination Project Conceptual Design

Additionally, a detailed review was made of previous evaluations and laboratory assessments relevant to the CAN-DEREM and LOMI Decontamination Process in order to identify potential corrosion consequences following a full RCS chemical decontamination.

Remarks/Potential for dose limitation: The only economically feasible way of significantly reducing the source term of a PWR is to chemically decontaminate the entire primary system. As a result of the evaluations performed, it has been demonstrated that full RCS chemical decontamination, using either the CAN-DEREM or LOMI process, can be performed with a high degree of confidence without significant impacts on plant equipment.

References: Miller, P.E., "Full Primary System Chemical Decontamination Qualification Program," Water Chemistry of Nuclear Reactor Systems 6, Vol. 1, pp. 89-96, British Nuclear Energy Society, London, 1992.

Duration: from: 1988 to: 1992

Funding: N/A

Status: Completed

Last Update: June 9, 1993 


\title{
FULL SYSTEM DECONTAMINATION AND COUNTERMEASURES AGAINST RECONTAMINATION OF THE FUGEN NUCLEAR POWER STATION
}

\author{
Keywords: CONTAMINATION REMOVAL; CONTAMINATION \\ PREVENTION; DOSE REDUCTION; DECONTAMINATION; FULL SYSTEM \\ DECONTAMINATION
}

\section{Principal Investigator:}

Y. Naoi

Power Reactor and Nuclear Fuel

Development Corporation

3 Myojin-cho

Tsuaruga-shi, FUKUI-KEN 914

JAPAN

Phone: +81 770261221
Project Manager:

T. Kitabata

Power Reactor and Nuclear Fuel

Development Corporation

3 Myojin-cho

Tsuaruga-shi, FUKUI-KEN 914

JAPAN

Phone: +81770261221

Objectives: This study describes the full system decontamination experiences and effects of endeavors against recontamination at Fugen Nuclear Power Station in Japan.

Comments: The system decontamination procedure consisted of four processes:

1. heating - the temperature of the reactor coolant was raised to $120^{\circ} \mathrm{C}$ after nitrogen had been injected to deoxidize the coolant

2. decontamination - the decontamination reagent Kuridecon-203 (KD-203) was added and circulated for 24 hours

3. purification - the decontaminate was purified to remove the reagent and radionuclides; conductivity of the coolant was reduced to $10 \mu \mathrm{S} / \mathrm{cm}$

4. purification and flushing - drain and bent tubes were flushed out or rinsed with pure water, and the primary coolant was purified completely until its conductivity was less than $1 \mu \mathrm{S} / \mathrm{cm}$; all the coolant was then discharged and refilled, and the purification, flushing and draining procedures were repeated.

Remarks/Potential for dose limitation: The two decontaminations in 1989 and 1991 saved occupational radiation doses of 6.6 and $7.8 \mathrm{man}-\mathrm{Sv}$ respectively. The ultrasonic fuel crud cleaning slightly lowered the recontamination rate after the decontamination of 1991 compared to that of 1989 without the cleaning. As a further countermeasure against recontamination, high-efficiency crud removal resins which reduce crud iron concentration in feedwater to less than $1 \mathrm{ppb}$ are under evaluation at Fugen.

References: Naoi, Y. et al, "Full System Chemical Decontamination and Countermeasures Against Recontamination of the Fugen Nuclear Power Station," Water Chemistry of Nuclear Reactor Systems 6, Vol. 1, pp. 97-104, British Nuclear Energy Society, London, 1992.

Duration: from: 1989 to: 1992

Funding: N/A

Status: Completed

Last Update: September 3, 1993 


\section{ELECTROCHEMICAL CORROSION POTENTIAL MEASUREMENT WITH A ROTATING CYLINDER ELECTRODE IN $288^{\circ} \mathrm{C}$ WATER}

\section{Keywords: COMPONENT RELIABILITY; IGSCC; ELECTROCHEMICAL CORROSION POTENTIAL; ROTATING CYLINDER ELECTRODE}

\section{Principal Investigator:}

C. Lin and Y.J. Kim

General Electric Nuclear Energy

P.O. Box 460

Pleasanton, CA 94566

U.S.A.

Phone: $415-862-4566$

\section{Project Manager:}

R. Pathania

Electric Power Research Institute 3412 Hillview Avenue, P.O. Box 10412

Palo Alto, CA 94309

U.S.A.

Phone: 415-855-2411

Objectives: This study focuses on a description of the test apparatus and the effects of water flow velocity on the electrochemical corrosion potential (ECP) behavior of stainless steel in $288^{\circ} \mathrm{C}$ water under simulated BWR conditions.

Comments: The ECP of 316 stainless steel was measured by using the rotating cylinder electrode under simulated BWR water chemistry conditions. It was demonstrated that the rotating cylinder electrode (RCE) is useful for measuring the ECP under hydrodynamic conditions in $288^{\circ} \mathrm{C}$ water. Because of the practical limitation and undefined hydrodynamic conditions by the pipe loop and the paddle wheel, the RCE is useful for practical evaluation of the effect of flow velocity on the kinetics of electrochemical processes.

Remarks/Potential for dose limitation: It has been shown that IGSCC susceptibility can be markedly decreased if the ECP can be decreased below a critical value. ECP behavior is known to be controlled by the dissolved $\mathrm{H}_{2}, \mathrm{O}_{2}$, and $\mathrm{H}_{2} \mathrm{O}_{2}$ concentrations in the BWR coolant and subsequently mass transfer rates of these species play an important role on ECP. Therefore, an acceleration of the electrochemical reactions of $\mathrm{H}_{2}$ and $\mathrm{O}_{2}$ caused by hydrodynamic water flow is expected to alter ECP behavior of stainless steel under various water chemistry conditions. The preliminary data have shown that the increase of the water flow velocity accelerates the oxygen reduction rate under various dissolved oxygen conditions and subsequently results in a positive ECP shift.

References: Kim, Y.J, Lin, C.C., and Pathania, R., "Electrochemical Corrosion Potential Measurement With a Rotating Cylinder Electrode in $288^{\circ} \mathrm{C}$ Water," Water Chemistry in Nuclear Reactor Systems 6, Vol. 1, pp. 139-144, British Nuclear Energy Society, London, 1992.

Duration: from: 1991 to: 1993

Status: In progress
Funding: N/A

Last Update: September 3, 1993 


\section{EFFECTS OF ZINC ADDITIONS ON THE CRACK GROWTH RATE OF SENSITIZED STAINLESS STEEL AND ALLOYS 600 AND 182 IN $288^{\circ} \mathrm{C}$ WATER}

Keywords: COMPONENT RELIABILITY; STRESS CORROSION CRACKING; ZINC; STAINLESS STEEL; ALLOY

\section{Principal Investigator:}

T. Diaz

General Electric Nuclear Energy

MC 783

175 Curtner Avenue

San Jose, CA 95125

U.S.A.

Phone: 408-925-4131

\author{
Project Manager: \\ P. Andresen \\ General Electric Corporate R \& D \\ K1-3A39 \\ 1 River Rd \\ Schenectady, NY 12309 \\ U.S.A.
}

Phone: 518-387-5929

Objectives: The goal of this study was to evaluate the effects of 5 to $10 \mathrm{ppb} \mathrm{Zn}^{2+}$ addition on the stress corrosion crack growth rates of sensitized Alloy 600 using $25 \mathrm{~mm}$ compact type (CT) specimens, and sensitized type 304 stainless steel and Alloy 182 weld metal using double cantilever beam (DCB) specimens.

Comments: $\mathrm{Zn}$ additions of 5 to $10 \mathrm{ppb}$ were consistently beneficial in reducing crack growth rates of sensitized Alloy 500 , sensitized type 304 steel, and Alloy 182 weld metal in $\sim 288^{\circ} \mathrm{C}$ water containing 0 or $200 \mathrm{ppb} \mathrm{O}_{2}$ and 0 to $0.4 \mu \mathrm{M} \mathrm{H}_{2} \mathrm{SO}_{4}$. The reduction in crack growth rate from $\mathrm{Zn}$ addition ranged from about a factor of 5 for sensitized type 304 stainless steel or Alloy 182 weld metal in $282^{\circ} \mathrm{C}$ pure water at low corrosion potential, to about a factor

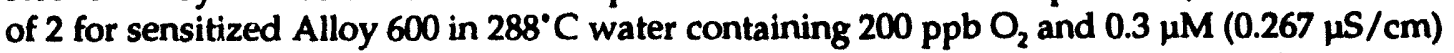
$\mathrm{H}_{2} \mathrm{SO}_{4}$. Approximately a factor of 2 was also observed in a four-inch diameter, weld sensitized type 304 stainless steel pipe.

Remarks/Potential for dose limitation: In the last several years, $\mathrm{ZnO}$ additions to BWR water have been studied, primarily because of their beneficial influence in reducing buildup of radioactive species such as Co-60 in the oxide film of structural components. Its success and lack of notable adverse side effects has resulted in its implementation in a few BWRs. However, no prior evaluation of $\mathrm{Zn}$ additions on crack growth has been performed.

References: Andresen, P.L., and Diaz, T.P., "Effects of Zinc Additions On the Crack Growth Rate of Sensitized Stainless Steel and Alloys 600 and 182 in 288. C Water," Water Chemistry of Nuclear Reactor Systems 6, Vol. 1, pp. 169-175, British Nuclear Energy Society, London, 1992.

Duration: from: 1991 to: 1992

Status: Completed
Funding: N/A

Last Update: September 3, 1993 


\section{ON-LINE MEASUREMENT OF PARTICLES IN REACTOR WATER OF BWRS}

\section{Keywords: CONTAMINATION PREVENTION; ON-LINE MEASUREMENT; RADIATION FIELD; WATER CHEMISTRY}

\section{Principal Investigator:}

W. Francioni

Paul Scherrer Institute

VILLIGEN CH5232

SWITZERLAND

Phone: +4156992111
Project Manager:

E. Schenker

Paul Scherrer Institute

VILLIGEN CH5232

SWITZERLAND

Phone: +41569921 11

Objectives: To measure the number, size, and composition of particles in the primary cooling water of a BWR.

Comments: A high temperature and pressure cell $\left(290^{\circ} \mathrm{C}, 90 \mathrm{bar}\right)$ was developed and tested in an out-of-pile loop. The equipment was subsequently used in cooled reactor water in the NPP Leibstadt. During steady state, power reduction, and the shutdown operation, the number and size of particles were measured. Additional chemical and radiological analyses were done to give information regarding particle composition. A POLYTEC HC 70 was used to measure suspended material in the reactor water. By measuring on-line, the investigators were able to determine at what times during the reactor cycle the activated products were bound to particles, and at what times they were "dissolved" and not bound.

Remarks/Potential for dose limitation: In the primary circuits of water cooled reactors, activated corrosion products such as Co-58, Co-60, and Mn-54 are transported and deposited on the walls. Since the deposited activity causes a radiation field that makes maintenance work more difficult, it would be of great importance to control the deposition process.

References: Schenker, E, Francioni, W., and DeGueldre, C., "On-line Measurement of Particles in Reactor Water of BWRs," Water Chemistry of Nuclear Reactor Systems 6, Vol. 1, pp. 133-139, British Nuclear Energy Society, London, 1992.

Duration: from: 1990 to: 1992 Funding: N/A

Status: Completed Last Update: June 10, 1993 


\title{
THE INTEGRITY OF INCONEL ALLOYS IN HIGH TEMPERATURE WATER CHEMISTRY
}

\section{Keywords: COMPONENT RELIABILITY; NICKEL; ALLOY; WATER CHEMISTRY; INCONEL}

\section{Principal Investigator:}

\author{
Project Manager:
}

\section{I.-J. Yang}

Industrial Technology Research Institute

National Tsing Hua University

101, Section 2, Kuang Fu Road

Hsinchu, TAIWAN 30043

REPUB. OF CHINA

Phone: 035715131

Objectives: To investigate the electrochemical behavior of nickel-based alloys using potentiodynamic technique in sulfate and/or chloride environments at $316^{\circ} \mathrm{C}$.

Comments: A low chromium alloy was designed to simulate the grain boundary composition of sensitized Inconel 600 . High pressure and temperature electrochemical technique was applied to evaluate the effect of sulfate and chloride ions on the corrosion behavior of nickel-based alloys. Anodic polarization scans were performed with a Solartron 1286 Electrochemical Interface that con umunicated with an HP computer at a scan rate of 1 $\mathrm{mV} / \mathrm{s}$. The platinum counter electrode and $\mathrm{Ag} / \mathrm{AgCl}$ reference electrode were maintained in de-aerated electrolytes. It was found that the trend of high temperature electrochemical polarization curves is a little different for nickel-based alloys in neutral, acidic, and alkaline solutions. Chloride ions tend to corrode metals catalytically, especially in highly acidic media, and sulfate ions are less damaging in the corrosion process, providing sulfate salts can be formed on active sites.

Remarks/Potential for dose limitation: High temperature water chemistry is a critical issue in determining the life assessment of heat exchanger tubes made of nickel-based alloys. There are two major contaminants, sulfate and chloride anions, that may be present in PWRs and affect the material performance. In creviced regions, the level of impurity concentration may be elevated by as much as four orders of magnitude. At high concentrations of sulfate and chloride ions, nickel-based alloys quite possibly suffer from a detrimental corrosion problem

References: Yang, I.-J., "The Integrity of Inconel Alloys in High Temperature Water Chemistry," Water Chemistry of Nuclear Reactor Systems 6, Vol. 1, pp. 177-180, British Nuclear Energy Society, London, 1992.

Duration: from: 1991 to: 1992 Funding: N/A

Status: Completed 


\title{
ENRICHED BORON PRODUCTS
}

Keywords: COMPONENT RELIABILITY; BORON; ENRICHED BORIC ACID; WATER CHEMISTRY; STRESS CORROSION CRACKING

\section{Principal Investigator:}

\author{
Project Manager:
}

Dr. Veronique Goehlich

Eagle-Picher Industries Materials GmbH

An der Lehmgrube 14

D-74613 OERINGEN

GERMANY

Phone: 49-7941-6030

Objectives: Document the usefulness of enriched boron products in nuclear power plants, specifically enriched boric acid at PWRs and enriched sodium pentaborate at BWRs.

Comments: In PWRs, boric acid is used as a solubility reactivity control agent and is referred to as a chemical shim because of the high capture cross section ( 3815 barns) for thermal neutrons exhibited by the boron 10 isotope contained in the boric acid. Using enriched boric acid (EBA), which is enriched to $99 \%$ B-10, allows for the decrease of total boron concentration without changing the boron 10 content of the reactor cooling water. In order to maintain the $\mathrm{pH}$ level of the water, the quantity of lithium hydroxide needed is dramatically reduced as well. This keeps the lithium limits below concentrations thought to accelerate Zircaloy corrosion and may eliminate or delay initiation of primary water stress corrosion cracking of steam generator tubes.

In order to upgrade the stand-by liquid control systems in BWRs, a solution more concentrated in boron 10 was needed. Enriched sodium pentaborate was developed for this purpose.

Remarks/Potential for dose limitation: The use of EBA could allow longer fuel cycles, reduced man-rem exposure, reduced maintenance costs, and prevent major plant modifications such as enlarging the boric acid tanks when going to lower concentrations or higher burn-up fuels. Greater safety, reduced corrosion and plant life extension are just some of the possible benefits of using enriched boron products.

References: Goehlich, V., "Enriched Boron Products," Water Chemistry of Nuclear Reactor Systems 6, Vol. 1, pp. 187-189, British Nuclear Energy Society, London, 1992.

Duration: from: 19 to: 1992

Status: In Progress
Funding: N/A

Last Update: September 3, 1993 


\section{VARIABILITIES IN THE CALCULATION OF PWR PRIMARY} COOLANT pH

Keywords: CONTAMINATION PREVENTION; PH; WATER CHEMISTRY

\section{Principal Investigator:}

M. Polley

Nuclear Electric

Berkeley Nuclear Laboratories

Berkeley, GLOUCESTER GL13 9PB

U.K.

Phone: UK r,453-812174

Objectives: $\mathrm{pH}$ values vary greatly with temperature and can vary significantly with different methods of calculation. In this paper, these variations are quantified in order to aid cross-comparison of literature values.

Comments: In the past, a variety of methods have been used leading to differences in values obtained for $\mathrm{pH}$. Up to the present, calculations have usually been at the inlet temperature (often approximated to $285^{\circ} \mathrm{C}$ ) or at $300^{\circ} \mathrm{C}$. The Electric Power Research Institute (EPRI) recommends calculation at the average primary coolant temperature, which is different in each plant and may vary with time. The results from two methods of $\mathrm{pH}$ calculation are graphed in this paper, and the discrepancies between the two can be seen.

Remarks/Potential for dose limitation: The lithium/boron regime adopted for primary coolant chemistry has an important effect on corrosion product activity transport and hence on dose rates around the primary circuit.

References: Polley, M.V., "Variabilities in the Calculation of PWR Primary Coolant pH," Water Chemistry of Nuclear Reactor Systems 6, Vol. 1, pp. 192-193, British Nuclear Energy Society, London, 1992.

Duration: from: 1991 to: 1992

Status: Completed
Funding: N/A

Last Update: September 3, 1993 
CONSTRUCTION AND OPERATION OF AN IN-PILE LOOP FOR BWR COOLANT CHEMISTRY STUDIES

Keywords: CONTAMINATION PREVENTION; COMPONENT RELIABILITY; PRIMARY COOLANT CHEMISTRY; CORROSION; NITROGEN

\section{Principal Investigator:}

Michael Driscoll

Massachusetts Institute of Technology

138 Albany St., NW13-259

Cambridge, MA 02139

U.S.A.

Phone: 617-253-4219
Project Manager:

Otto Harling

Massachusetts Institute of Technology

138 Albany St., NW13-259

Cambridge, MA 02139

U.S.A.

Phone: 617-253-4219

Objectives: This paper discusses the construction and operation at the MIT Research Reactor of an in-pile loop which simulates BWR coolant conditions. The loop was designed to carry out coolant radiolysis studies, with a focus on $\mathrm{O}_{2}$ and $\mathrm{H}_{2} \mathrm{O}_{2}$ generation, electrochemical corrosion potential, and $\mathrm{N}-16$ chemistry.

Comments: The BWR Coolant Chemistry Loop (BCCL) had once-through flow. Neutron and gamma dose rates and core exit quality are comparable to those in an actual BWR. With the exception of the in-core Zircaloy tubing, the system is constructed almost entirely of titanium to insure water purity, and a chemical injection system is provided for controlled addition of chemicals of interest. Charging tank cover gas composition can be varied to simulate a range of conditions between NWC and HWC, or to add a wide variety of gaseous species for test purposes.

Remarks/Potential for dose limitation: Coolant chemistry in a BWR has important effects on materials integrity, ex-core radionuclide deposit, and steam plant dose rates.

Radiolysis dominates and is hard to quantify fully by computation alone. This motivated the construction and operation of this experimental facility.

References: Kohse, G.E. et al, "Construction and Operation of an In-Pile Loop for BWR Coolant Chemistry Studies," Water Chemistry of Nuclear Reactor Systems 6, Vol. 1, pp. 190-191, British Nuclear Energy Society, London, 1992.

Duration: from: 1991 to: 1992

Funding: N/A

Status: Completed

Last Update: June 11, 1993 


\section{WATER CHEMISTRY DURING THE SHUT-DOWN OF THE}

BOILING WATER REACTOR LEIBSTADT

Keywords: CONTAMINATION PREVENTION; WATER CHEMISTRY; SHUTDOWN CHEMISTRY; PARTICULATE; HYDROGEN PEROXIDE; CORROSION PRODUCT

Principal Investigator:

W. Blaser

Nuclear Power Plant Leibstadt

LEIBSTADT CH-4353

SWITZERLAND

Phone: +415647 7111
Project Manager:

E. Schenker

Paul Scherrer Institute

VILLIGEN CH-5232

SWITZERLAND

Phone: +415699 2111

Objectives: In order to better understand the reasons for activity increase in reactor water during shut-down, an extensive measuring campaign was carried out during the shut-down of the BWR Leibstadt (KKL).

Comments: The measurements began at $72 \%$ total power, or 70 hours before zero power, and lasted until 80 hours after zero power. Particle size, size distribution, corrosion product concentrations ( $\mathrm{Fe}, \mathrm{Ni}, \mathrm{Cr}, \mathrm{Mn}, \mathrm{Co}$, and $\mathrm{Zn}$ ), and hydrogen peroxide concentration were measured.

Remarks/Potential for dose limitation: Peaks in activity are mainly caused by undissolved corrosion products. The concentration of hydrogen peroxide increased rapidly when the temperature dropped below $160^{\circ} \mathrm{C}$.

References: Wedda, H., Loner, H. and Schenker, E., "Water Chemistry During the Shut-Down of the Boiling Water Reactor Leibstadt," Water Chemistry of Nuclear Reactor Systems 6, Vol. 1, pp. 194-195, British Nuclear Energy Society, London, 1992.

Duration: from: 1991 to: 1992 Funding: N/A

Status: Completed Last Update: June 11, 1993 


\section{SOLUBILITY OF COBALT IN PRIMARY CIRCUIT SOLUTIONS}

\section{Keywords: CONTAMINATION PREVENTION; PRIMARY COOLANT CHEMISTRY; COBALT; SOLUBILITY}

\section{Principal Investigator:}

\section{Lambert}

CEA

Centre d'Etudes

Service d'Etudes Nucleaires

BP No.6

92265 Fontenay-aux-Roses Cedex

FRANCE

Phone:
Project Manager:

F. Joyer

CEA

Centre d'Edudes

Services d'Etudes Nucleaires

BP No.6

92265 Fontenay-aux-Roses Cedex FRANCE

Phone:

Objectives: The solubility of cobalt ferrite $\left(\mathrm{CoFe}_{2} \mathrm{O}_{4}\right)$ was measured in PWR primary circuit conditions in the temperature range $250-350^{\circ} \mathrm{C}$. The results were compared with the ones obtained on magnetite and nickel ferrite.

Comments: It was found that in prevailing primary circuit conditions, the solutility of the cobalt ferrite was minimum at temperatures around $300^{\circ} \mathrm{C}$. The equilibrium iron concentration is significantly lower than in the case of magnetite. The results are discussed in relation with the POTHY code, based only on thermodynamic laws and data, which was used for the prediction of the primary circuit chemistry.

Remarks/Potential for dose limitation: The agreement generally observed between equilibrium constants issued from experimental data and from direct calculation by POTHY confirm the validity of this code for any application in the primary circuit chemistry.

References: Lambert, I. and Joyer, F., "Solubility of Cobalt in Primary Circuit Solutions," Water Chemistry of Nuclear Reactor Systems 6, Vol. 1, pp. 196-197, British Nuclear Energy Society, London, 1992.

Duration: from: 1991 to: 1992

Funding: N/A

Status: Completed

Last Update: June 14, 1993 


\section{STATISTICAL ANALYSIS OF REACTOR WATER DATA}

\section{Keywords: CONTAMINATION PREVENTION; COBALT; RADIATION BUILDUP; MATHEMATICAL MODELS}

\section{Principal Investigator:}

H.-P. Alder

Paul Scherrer Institute

CH-5232 Villigen-PSI

SWITZERLAND

Phone: +41569921 11

\section{Project Manager:}

H. Loner

Paul Scherrer Institute

CH-5232 Villigen-PSI

SWITZERLAND

Phone: +4156992111

Objectives: To show that regression analysis is a simple tool to get an idea of which impurities in a reactor are important for the transport and deposition of $\mathrm{Co}-60$ for further mechanistical studies.

Comments: The reactor water in BWRs is analyzed regularly and it is possible to obtain much information from these analyses. In this work, the regression analysis was chosen to produce empirical models for the Co-60 activity in the reactor water, taking account of other impurities over a time period where the reactor water chemistry was changed dramatically. The most simple regression is the linear regression:

$y=X a+b \quad$, where

$y \quad$ vector of dependent variable

$X \quad$ matrix including one constant predictor and $m$ vectors $x_{i}$ of explanatory variables

a estimated parameters

b residuals of the model compared to the measured values

Remarks/Potential for dose limitation: Mathematical modeling of the primary cooling system helps to see effects in the activity buildup due to changes in the reactor water chemistry. The primary cooling system of a BWR is a very complex system and difficult to model, but various efforts have been made creating mathematical models for radiation control in the primary system.

References: Loner, H., Alder, H.-P., Covelli. B., "Statistical Analysis of Reactor Water Data," Water Chemistry of Nuclear Reactor Systems 6, Vol. 1, pp. 200-201, British Nuclear Energy Society, London, 1992.

Duration: from: 1991 to: 1992

Status: Completed
Funding: N/A

Last Update: June 11, 1993 


\section{BNL ALARA Center Data Base}

\section{MIXED OXIDE-ALLOY-WATER SYSTEMS UNDER LWR CONDITIONS}

Keywords: COMPONENT RELIABILITY; CORROSION; OXIDE FILM; PH

\section{Principal Investigator:}

D. Cubicciotti

Electric Power Research Institute

P O Box 10412

Palo Alto, CA 94303

U.S.A.

Phone: 415-855-2069

Objectives: To calculate the potential-pH diagrams for $\mathrm{Fe}-\mathrm{Cr}-\mathrm{Ni}$ alloys and for Fe-Zn systems, showing the regions of stability for mixed oxides.

Comments: The diagrams are only first approximations to the water-alloy equilibrium. They emphasize the fact that mixed oxides can form on the metal surface, with substantial impact on the pH-potential fields of stability and hence on the corrosion behavior of the metal. Better diagrams can be calculated when thermodynamic data become available for the Gibbs energy of formation of: a) the mixed oxides, especially those containing three or more metals, b) the ions in solution, which were approximated values.

Remarks/Potential for dose limitation: The corrosion of construction materials causes problems for reactors in the hot water in BWRs and PWRs, and in the room temperature water of service water systems. In corrosion processes, one must consider the kinds of films formed on the surface of the corroding metal, which are different for alloys from pure metals because of the formation of mixed oxides involving two or more of the constituent elements. To help in the corrosion analysis of alloys, the potential-pH diagrams were calculated.

References: Cubicciotti, D., "Mixed Oxide-Alloy-Water Systems Under LWR Conditions," Water Chemistry of Nuclear Reactor Systems 6, Vol. 1, pp. 206-207, British Nuclear Energy Society, London, 1992.

Duration: from: 1991 to: 1992 Funding: N/A

Status: Completed Last Update: September 3, 1993 


\section{MAXIMUM ALLOWABLE CHLORIDE LEVELS ON STAINLESS STEEL COMPONENTS AT THE SIZEWELL "B" PWR}

\section{Keywords: COMPONENT RELIABILITY; STRESS CORROSION CRACKING; INTERGRANULAR ATTACK; CHLORIDE; PITTING}

\section{Principal Investigator:}

S. Allan

NNC Ltd, Booths Hall

Chelford Road

Knutsford, CHESHIRE WA16 8QG

U.K.

Phone: +44565 633800
Project Manager:

W. Lawson

Nuclear Electric plc

Chelford Road

Knutsford, CHESHIRE WA16 $8 Q$ G

U.K.

Phone: +44565682659

Objectives: Assess the environmental conditions and chloride contamination levels under which corrosion (stress corrosion cracking, intergranular attack, and pitting) could occur at the Sizewell "B" PWR.

Commento: There are two distinct sets of conditions where a stainless steel plant could experience corrosion, namely those associated with storage when the plant is part-constructed and stored on site before final fabrication, and those which would be experienced by the plant during operation. As Sizewell is a coastal location, it was anticipated that the vendor-specified maximum chloride level of $0.015 \mu \mathrm{g} / \mathrm{cm}^{2}$ would be difficult to achieve and maintain during construction and operation. In order to define what levels could be allowed, work was commissioned to establish levels of chloride that could initiate corrosion on typical Sizewell "B" stainless steel material over a range of typical conditions simulating storage and plant operation.

Remarks/Potential for dose limitation: The level of chloride contamination allowed on PWR stainless steel is governed by requirement to avoid corrosion associated with chlorides, including stress corrosion cracking, intergranular attack, and pitting. Based on the results of this study, a maximum chloride level of $0.1 \mu \mathrm{g} / \mathrm{cm}^{2}$ would be appropriate for Sizewell "B". This will give a margin of safety and is attainable with appropriate care.

References: Allan, S.J., Atherton, D. and Lawson, W.F., "Maximum Allowable Chloride Levels on Stainless Steel Components at the Sizewell 'B' PWR," Water Chemistry of Nuclear Reactor Systems 6, Vol. 1, pp. 210-211, British Nuclear Energy Society, London, 1992.

Duration: from: 1991 to: 1992

Status: Completed
Funding: N/A

Last Update: June 14, 1993 


\section{INORGANIC SEED MATERIALS FOR THE DECONTAMINATION OF PWR AQUEOUS WASTES}

\section{Keywords: CONTAMINATION REMOVAL; WASTE FILTRATION; INORGANIC SEED MATERIAL}

\section{Principal Investigator:}

E. Hooper

AEA Technology

B465 Harwell

Didcot, Oxfordshire OX11 ORA

U.K.

Phone: +44 235435555
Project Manager:

R. Sellers

Nuclear Electric plc

Timpson Road

Wythenshawe, Manchester M23 9LL

U.K.

Phone: +44619464202

Objectives: Study the use of several inorganic sorbents, used in combination with crossflow membrane filtration, for the reduction of $\mathrm{Cr}-51$ and Sb-125 levels in a PWR waste stream.

Comments: By adding to the waste effluent small quantities of solid "seed" materials onto which dissolved radionuclides can become absorbed, soluble contaminants can be removed to produce a clean effluent. Seeds specific to a number of different radionuclides have been identified (e.g. nickel hexacyanoferrate (II) for Cs-137). By employing a mixture of different seed materials, a wide spectrum of radionuclides can be dealt with. A mixture of titanium oxide, zirconium phosphate, and sodium nickel hexacyanoferrate (II) gave an overall decontamination factor of 20 at a solution $\mathrm{pH}$ of 4.5.

Remarks/Potential for dose limitation: Ultrafiltration is a filtration process that enables particles as small as $\mathbf{2 n m}$ in size to be removed from liquid suspension. Some aqueous waste streams arising at nuclear power plants are contaminated with very low levels of radioactive nuclides typically in the sub- $\mu \mathrm{g} \cdot \mathrm{kg}^{-1}$ range. Many of the radionuclides in the wastes are present as colloidal or insoluble material and can therefore be potentially removed using ultrafiltration. Soluble species cannot be filtered directly, and inorganic seed materials must be used.

References: Hooper, E.W., Kavanagh, P. and Sellers, R.M., "Inorganic Seed Materials for the Decontamination of PWR Aqueous Waste'," Water Chemistry of Nuclear Reactor Systems 6, Vol. 1, pp. 214-215, British Nuclear Energy Sor.lety, London, 1992.

Duration: from: 1991 to: 1992

Funding: N/A

Status: Completed

Last Update: June 14, 1993 


\title{
EASY INEXPENSIVE HYDROGEN WATER CHEMISTRY PREDICTIVE METHODS
}

\section{Keywords: COMPONENT RELIABILITY; HYDROGEN WATER CHEMISTRY; IGSCC; COST REDUCTION}

\section{Principal Investigator:}

\author{
Project Manager:
}

M. Fox

Aptech Engineering Services Inc.

Tucson, AZ

U.S.A.

Phone:

Objectives: This study invortigated inexpensive and simple hydrogen water chemistry (HWC) predictive methods that eliminate the need for HWC minitests.

Comments: HWC is the addition of hydrogen to the feedwater of a boiling water reactor. The hydrogen reduces the concentration of dissolved oxygen in the primary coolant to a level that will no longer facilitate intergranular stress corrosion cracking of stainless steel components. Each BWR responds differently to such hydrogen injections which lead to expensive HWC minitests. The main difference between the Aptech HWC predictive methods and a minitest is that no hydrogen needs to be added to the feedwater. Rather, the predictive methods utilize the indigenous hydrogen and oxygen generated by radiolysis in the core.

Remarks/Potential for dose limitation: The ability of any specific downcomer/jet pump region to facilitate the recombination of hydrogen and oxygen varies from plant to plant. This has required expensive HWC minitests in order to determine the precise amount of feedwater hydrogen needed to reduce the ability of the recirculating water to facilitate IGSCC of the external recirculation piping, typically made of welded steel. Such mini tests cost upwards of $\$ 1.0$ million.

References: Fox, M., "Easy Inexpensive Hydrogen Water Chemistry Predictive Methods," Water Chemistry of Nuclear Reactor Systems 6, Vol. 1, pp. 222-223, British Nuclear Energy Society, London, 1992.

Duration: from: 1990 to: 1992

Funding: N/A

Status: Completed

Last Update: June 16, 1993 


\section{POTENTIAL-pH DIAGRAMS FOR ALLOY-WATER SYSTEMS UNDER LWR CONDITION}

\section{Keywords: COMPONENT RELIABILITY; POURBAIX DIAGRAM; CORROSION; OXIDE FILM; MIXED OXIDE}

\section{Principal Investigator:}

Daniel Cubicciotti

Electric Power Research Institute

P O Box 10412

Palo Alto, CA 94303

U.S.A

Phone: 415-855-2069

Objectives: To calculate from thermodynamic data the regions of oxide compound stability (Pourbaix diagrams) for the water-Fe-Cr-Ni system at room temperature and at typical LWR temperature. Diagrams for $\mathrm{Fe}-\mathrm{Cr}$-water, $\mathrm{Fe}-\mathrm{Ni}$-water, and $\mathrm{Cr}$ - $\mathrm{Ni}$-water systems are also given.

Comments: Potential-pH or Pourbaix diagrams present the regions of stability of metallic species with water. They indicate the areas of potential and $\mathrm{pH}$ in which the dissolved species, the metal oxides, or the metal itself is stable. Regions for stable dissolved species are ones in which the metal can undergo corrosion. Where the metal itself is the stable form, the region is one of immunity. In the regions where the metal oxide is stable, the oxide can form on the metal as a protective layer.

Remarks/Potential for dose limitation: Corrosion of the PWR or BWR infrastructure contribute greatly to the overall radiation level. Controlling the $\mathrm{pH}$ of the primary water coolant is one method for reducing corrosion of metal surfaces. Pourbaix diagrams can contribute to this effort by identifying the ideal $\mathrm{pH}$ for metal or metal oxide stability.

References: Cubicciotti, D., "Potential-pH diagrams for alloy-water systems under LWR conditions," Journal of Nuclear Materials, Vol. 201, p. 176-183, 1993.

Duration: from: 1992 to: 1992

Funding: N/A

Status: Completed
Last Update: August 25, 1993 


\section{IN-PILE LOOP STUDIES OF CLOSE REDUCTION TECHNOLOGIES FOR PWRs AND BWRs; INVESTIGATIONS OF MATERIAL SUSCEPTIBILITY TO CRACKING}

Keywords: CONTAMINATION PREVENTION; COMPONENT RELIABILITY; WATER CHEMISTRY; PH; N-16 CARRYOVER; STRESS CORROSION CRACKING

\section{Principal Investigator:}

Michael Driscoll

Massachusetts Institute of Technology

138 Albany St., NW13-259

Cambridge, MA 02139

U.S.A.

Phone: 617-253-4219

\section{Project Manager:}

Otto Harling

Massachusetts Institute of Technology

138 Albany St., NW13-259

Cambridge, MA 02139

U.S.A.

Phone: 617-253-4219

Objectives: 1. For BWRs, reduce N-16 carryover by optimizing chemistry.

2. For PWRs, reduce radioactive corrosion product build up on the primary cooling surface by $\mathrm{pH}$ optimization of the water chemistry.

3. Reduce irradiation assisted stress corrosion cracking on core structural materials.

\section{Comments:}

Remarks/Potential for dose limitation: All of the research have the potential for major reductions in operational dose commitments in LWRs.

\section{References:}

1) "In-Pile Facilities for LWR materials and Chemistry Studies at the MIT Research Reactor,"

O.K. Harling, G.E. Kohse, M.J. Driscoll, R.G. Ballinger, JAIF Conference, Fukui City (1991)

2) "In-Pile PWR Loop Coolant Chemistry Studies in Support of Dose Reduction," G.E. Kohse, R.G. Sanchez, M.J. Driscoll, M. Ames, and O.K. Harling, JAIF Conference, Fukui City (1991)

3) "Development and Use of an In-pile Loop for BWR Chemistry Studies", EPRI TR-102248, July 1993.

Duration: from: 1985 to: 1993

Funding: $\$ 0.5$ to $1.5 \mathrm{M} / \mathrm{yr}$

Status: In progress

Last Update: August 26, 1993 


\section{BNL ALARA Center Data Base}

U.S.A.

\section{EVALUATION OF FACTORS AFFECTING RADIATION FIELD TRENDS IN WESTINGHOUSE-DESIGNED PLANTS}

\section{Keywords: OPERATIONAL AND MAINTENANCE TECHNIQUES; RADIATION FIELD TREND; RADIATION FIELD CONTROL; RADIATION FIELD; COBALT; WATER CHEMISTRY; STEAM GENERATOR; DECONTAMINATION}

\section{Principal Investigator:}

John D. Perock

Westinghouse Electric Corporation

Nuclear \& Advanced Technology Division

P.O. Box 355

Pittsburgh, PA 15230-0355

U.S.A.

Phone: 412-374-5788

\section{Project Manager:}

Carl A. Bergmann

Westinghouse Electric Corporation

Nuclear \& Advanced Technology Division

P.O. Box 355

Pittsburgh, PA 15230-0355

U.S.A.

Phone: 412-374-5166

Objectives: Quantify the effects of cobalt input variations, operational chemistry, steam generator replacements, and decontamination on plant dose rates.

Comments: This is a summary of the third report of the Standard Radiation Monitoring Program initiated by Westinghouse and EPRI in 1977. It discusses the evaluation techniques and presents the results of the evaluation.

Remarks/Potential for dose limitation: Some of the changes in radiation fields are:

- Plant startup with Zircaloy vs Inconel fuel grids: $19 \%$ reduction

- Coordinated vs Uncoordinated. Chemistry: $15 \%$ reduction

- Inconel fuel grids without high cobalt impurity vs ones with high impurity: $18 \%$ reduction

- Overall improvement with initial Zircaloy fuel grids and coord. chemistry: $45 \%$ reduction

- channel head radiation levels in plants that have replaced steam generators with low Co impurity tubing are $65 \%$ of previous levels

- The dose rate in channel heads that have been chemically decontaminated builds up to only $60 \%$ of pre-decontamination levels

- Modified primary coolant chemistry (PCC) results in about $25 \%$ lower component dose rates compared with coordinated PCC

- An elevated coolant $\mathrm{pH}$ results in lower radiation levels by a factor of two compared to modified or coordinated $\mathrm{pH}$

- Plants started in 1985 and after have a factor of 2 less doses compared to pre-1985 plants

References: Bergmann, C.A., Perock, J.D., "Evaluation of Factors Affecting Radiation Field Trends in Westinghouse-Designed Plants," Water Chemistry of Nuclear Reactor Systems 6, Vol. 2, pp. 16-23, British Nuclear Energy Society, London, 1992.

Duration: from: 1977 to: 1991

Status: Completed
Funding: N/A

Last Update: August 27, 1993 


\section{THE MECHANICS AND KINETICS OF CORROSION PRODUCT} RELEASE FROM CARBON STEEL IN LITHIATED HIGH TEMPERATURE WATER

Keywords: CONTAMINATION PREVENTION; COBALT RELEASE; CORROSION PRODUCT RELEASE; OXIDE FILM

\section{Principal Investigator:}

Heather Allsop

AECL Research

Station 61 AECL

Chalk River, ONTARIO KOJ 1 JO

CANADA

Phone: 613-584-3311 Ext. 3268
Project Manager:

D. Lister, Norm Arbeau

University of New Brunswick

PO Box 4400

Fredericton, NEW BRUNSWICK E3B 5AE

CANADA

Phone: 506-453-5138

Objectives: A Formulation of the Cobalt Release from Carbon Steel

Comments: Data has been analyzed. Paper in preparation for publication.

Remarks/Potential for dose limitation: Understanding cobalt transport will have a large bearing on reducing radiation fields.

References: In preparation

Duration: from: 1991 to: 1993

Funding: N/A

Status: Completed

Last Update: August 30, 1993 


\section{INVESTIGATION OF THE CHEMICAL AND PHYSICAL PROPERTIES OF SPINEL OXIDES}

Keywords: CONTAMINATION PREVENTION; COBALT RELEASE; CORROSION PRODUCT RELEASE; OXIDE FILM

Principal Investigator:

P. McKenzie

University of New Brunswick

PO BOX 4400

Fredericton, New Brunswick E3B 5A3

CANADA

Phone:
Project Manager:

D. Lister

University of New Brunswick

PO Box 4400

Fredericton, New Brunswick E3B 5A3

CANADA

Phone: 506-453-5138

Objectives: To determine the affinity of various corrosion product spinels to the oxide layers formed by corrosion product release in high temperature water

Comments:

Remarks/Potential for dose limitation: Possible mechanisms for trapping various radioactive species will be studied. These directly influence the buildup of radiation fields.

References: In preparation

Duration: from: 1993 to: 1993

Funding: N/A

Status: Initiated

Last Update: August 30, 1993 


\section{BNL ALARA Center Data Base}

U.K.

\section{OVERVIEW OF THE IMPACT OF STELLITE REMOVAL ON RADIATION FIELDS IN KWU PWRs}

Keywords: CONTAMINATION PREVENTION; STELLITE; HARD ? ACING ALLOY; COBALT SOURCE; STAINLESS STEEL; RADIATION FIELD

\section{Principal Investigator:}

Project Manager:

K. Garbett

Nuclear Electric plc

Berkeley Technology Centre

Berkeley, Gloucestershire GL13 9PB

U.K.

Phone: +44 452812318

Objectives: Determine the following based upon data from Siemens PWRs:

1) the effect of a progressive reduction in Stellite on radiation fields

2) the consequences of replacing Inconel 718 gridded fuel by Zircaloy

3) the effect of eliminating antimony from the main coolant pump bearings

4) the effect of an increase in the $\mathrm{pH}$ of the primary coolant

Comments: This study updates an earlier analysis covering data collected up to 1989 on primary circuit activity levels and radiation fields from Siemens (KWU) PWRs. The work covers $\mathrm{Co}-60, \mathrm{Co}-58$, and $\mathrm{Sb}-124$ concentrations in the primary coolant and deposition on primary circuit surfaces.

\section{Remarks/Potential for dose limitation:}

1. Stellite, other than in the control rod drive mechanisms, is the major contributor of Co-60

2. Cobalt in the primary circuit structural materials are minor contributors to radiation fields

3. In-vessel Stellite is the most important Stellite source

4. Co-60 contributions to dose rates correlate with cycle-averaged total Co-60 concentrations in the primary coolant

5. Co-58 production showed no particular trend from plant to plant as Stellite was reduced

6. Co-58 contributions to dose rates were reduced on replacing Inconel 718 gridded fuel with Zircaloy gridded fuel

7. $\mathrm{Sb}-124$ contributions to dose rates and circulating coolant concentrations were low for plants commissioned with antimony-free main coolant pump bearings

8. $\mathrm{Sb}-124$ is a significant contributor to dose rates

9. Operation with the KWU/VGB high $\mathrm{pH}$ regime in Siemens PWRs reduced dose rates

10.The later KWU PWRs, which have eliminated both Stellite and antimony sources, have extremely low primary circuit radiation fields and yearly personnel doses

References: Garbett, K., "Overview of the Impact of Stellite Removal on Radiation Fields in KWU PWRs," Water Chemistry of Nuclear Reactor Systems 6, Vol. 2, pp. 31-38, British Nuclear

Energy Society, Lonaon, 1992.

Duration: from: 1989 to: 1992

Funding: N/A

Status: Completed

Last Update: August 30, 1993 


\section{ACTIVITY TRANSPORT AND CORROSION PROCESSES IN}

\section{PWRs}

Keywords: CONTAMINATION PREVENTION; WATER CHEMISTRY; PH; PWR COOLANT; COBALT; COBALT SOURCE; CORROSION; CRUD; CRUD TRANSPORT; CORROSION PRODUCT TRANSPORT; CORROSION PRODUCT DEPOSITION; CORROSION PRODUCT

Principal Investigator:

Project Manager:

D. Lister

University of New Brunswick

PO Box 4400

Fredericton, New Brunswick E3B 5AE

CANADA

Phone: $506-453-5138$

Objectives: Outline current understanding of activity processes in PWRs.

Comments: This study discusses the major scientific principles underlying the ieduction of radioactivity within reactor systems and the controlling of radiation fields around components. The following topics are covered:

I. Basic Theory of Activity Transport

II. The Production of Radioactive Species
A) Particle Transport
B) Particle Formation
C) In-core Processes Involving Dissolved Cobalt
D) Sources of Cobalt

III. The Activation of Out-of-Core Surfaces

Remarks/Potential for dose limitation:

1) Solubility differences move corrosion product oxides between in-core and out-of-core surfaces.

2) The source of dissolved corrosion products, especially cobalt, is described in terms of "corrosion release" from corroding surfaces.

3) The contamination of cut-of-core surfaces is dependent upon the contamination parameter, which describes the properties of the oxides growing on the surfaces.

4) From information on cobalt adsorption-desorption processes on in-core materials, coupled with the release and incorporation processes on out-of-core surfaces, a simple model for the evolution of total cobalt concentration in PWR coolant can be devised.

References: Lister, D.H., "Activity Transport and Corrosion Processes in PWRs," Water Chemistry of Nuclear Reactor Systems 6, Vol. 2, pp. 49-60, British Nuclear Energy Society, London, 1992.

Duration: from: 1990 to: 1992

Funding: N/A

Status: Completed

Last Update: August 31, 1993 


\section{FEASIBILITY OF ON-LINE MONITORING OF STRESS CORROSION CRACKING IN ROTATING COMPONENTS}

Keywords: COMPONENT RELIABILITY; STRESS CORROSION CRACKING; CORROSION MONITORING; CORROSION TESTING; ON-LINE MONITORING

\author{
Principal Investigator: \\ Dr. William M. Cox \\ CAPCIS MARCH Ltd \\ Bainbridge House \\ Granby Row \\ Manchester M1 2PW \\ U.K. \\ Phone: 44612365951
}

\author{
Project Manager: \\ Barry Syrett \\ Electric Power Research Institute \\ Office of Exploratory and Applied Research \\ P.O. Box 10412 \\ Palo Alto, CA 94303 \\ U.S.A.
}

Phone: 415-855-2956

Objectives: To demonstrate the feasibility of sending electrochemical signals telemetrically between an instrumented stress corrosion cracking (SCC) specimen and a data acquisition system.

Comments: A method of SCC monitoring involving the measurement of electrochemical current noise (ECN), electrochemical potential noise (EPN), and zero resistance ammeter (ZRA) signals has been developed recently. In this demonstration, the test apparatus consisted of a working electrode - a compact tension specimen made from $3 \mathrm{CrMo}$ steel - stressed in $a \mathbf{3 0}$ $w t \%$ sodium hydroxide solution at $75^{\circ} \mathrm{C}$. Unstressed counter-electrodes of the same material, also immersed in the caustic solution close to the precracked region of the compact tension specimen, allowed measurement of the ECN, EPN, and ZRA signals generated during stress corrosion crack growth. A prototype single-channel data transmission unit received ECN signals from the electrodes and transmitted them telemetrically to the antenna of a signal receiver unit positioned a short distance away.

Remarks/Potential for dose limitation: SCC was detected in the specimens by means of the ECN signals received. The ECN signals were successfully digitized and transmitted at radio frequencies across an air gap to a receiver and decoder, where they were converted to signals suitable for conventional processing and storage. Future SCC detection systems based on this principle can significantly reduce the manual labor needed for SCC inspection, thereby reducing worker radiation dosage.

References: "Feasibility of On-Line Monitoring of Stress Corrosion Cracking in Rotating Components," EPRI TR-102537 Final Report, Electric Power Research Institute, Palo Alto, CA, June 1993.

Duration: from: 1991 to: 1993

Status: Completed
Funding: N/A

Last Update: August 31, 1993 


\section{CONCEPT AND EXPERIENCE OF SYSTEM DECONTAMINATION WITH CORD}

Keywords: CONTAMINATION REMOVAL; CORD PROCESS; DECONTAMINATION; FULL SYSTEM DECONTAMINATION; SUB-SYSTEM DECONTAMINATION; COBALT REMOVAL

\section{Principal Investigator:}

H.C. Wille

Siemens AG KWU

Hammerbacherstr $12+14$

D-8520 Erlangen

GERMANY

Phone: 499131183339

\section{Project Manager:}

H. O. Bertholdt

Siemens

Hammerbacherstr $12+14$

D-8520 Erlangen

GERMANY

Phone:

Objectives: Outline the Siemens concept for the decontamination of systems with the CORD process. The results of sub-system and full-system decontaminations of a PWR and a BWR is presented.

Comments: The latest decontamination processes used by Siemens AG KWU may be characterized as follows:

- low chemical concentrations

- simple analytical monitoring

- short treatment cycles of a few hours with continuous adjustment of the chemical concentration

- waste reduction to the virtual elimination of secondary waste

The use of permanganic acid as oxidation agent in the process makes it possible to perform a decontamination cycle (oxidation, reduction, and decontamination) with only one system fill, thereby avoiding an intermediate cleanup and rinsing and reheating step.

Also, the CORD process does not leave chelating agents in the final waste.

There is virtually no external equipment required for the decontaminations of Siemens PWR primary loop. But for Westinghouse built 3 loop units and BWRs, additional purificaition equipment is required.

\section{Remarks/Potential for dose limitation:}

- A recirculation loop decontamination at the 640 MWe NPP Wurgassen led to a saving in personnel dose of $2000 \mathrm{mSv}$.

- During the decontamination of the sealing water supply system of the internal axial flow pumps with CORD in a German BWR (KKI), the personnel dose was reduced by $300-400 \mathrm{mSv}$.

- CORD was applied in 1990 and 1991 to Swedish BWR (OKG) subsystems. The two decontaminations resulted in savings of 250 and $200 \mathrm{mSv}$ for the repair and inspection work respectively. 


\section{BNL ALARA Center Data Base}

GERMANY

- In 1991, a FSD with CORD at the BR3 in Mol/Belgium resulted in personnel dose savings between 4000 and $8000 \mathrm{mSv}$ for subsequent dismantling operations.

References: Wille, H., Bertholdt, H.O., "Concept and Experience of System Decontamination with CORD," Water Chemistry of Nuclear Reactor Systems 6, Vol. 2, pp. 161-167, British Nuclear Energy Society, London, 1992.

Duration: from: 1991 to: 1992

Funding: N/A

Status: Completed

Last Update: September 1, 1993 


\section{ELOMIX: A BETTER WAY OF HANDLING THE WASTE FROM DECONTAMINATION}

Keywords: CONTAMINATION REMOVAL; DECONTAMINATION; LOMI; ELOMIX; RADWASTE MINIMIZATION; WASTE VOLUME REDUCTION

\section{Principal Investigator:}

David Bradbury

Bradtec Ltd.

The University of the West of England

Coldharbour Lane, Bristol BS16 1QY

U.K.

Phone: 440272763937

\section{Project Manager:}

C. Wood

Electric Power Research Institute

P.O. Box 10412

Palo Alto, CA 94303

U.S.A.

Phone: 415-855-2379

Objectives: To develop and verify the electrochemical LOMI Ion Exchange (ELOMIX) process for subsystem and possibly full system decontamination.

Comments: The ELOMIX process has the advantage of reducing the volume of secondary decontamination waste and transferring the contaminants into a stable inorganic form. This is accomplished by means of an electrochemical cell consisting of resin sandwiched between the anode and cathode. The radioactive debris are deposited at the cathode.

A small prototype ELOMIX cell was successfully tested at Commonwealth Edison's Dresden unit 2 in Oct. 1990. In May 1992, a larger scale cell capable of processing 30 litres/hr was constructed and demonstrated at Gulf States Utilities River Bend plant. The larger demo has shown that: 1) the ELOMIX system can be cleaned and transported, and 2) the metallic waste can be transferred hydraulically, enabling efficient treatment. Work is ongoing to build one full scale cell for design verification.

Remarks/Potential for dose limitation: The benefits of this process are:

1) Reduction in waste volume by factors of up to 140.

2) Conversion of the radioactive waste into a chemically more stable inorganic form.

3) The possibility of long term on-site storage of the waste.

References: Tucker, P. M., "ELOMIX: A Better Way of Handling the Waste From Decontamination", Nuclear Engineering International, Vol. 38, No. 463, pp. 18-21, Feb 1993.

Duration: from: 1989 to: 19

Status: In progress

\section{Funding:}

Last Update: August 19, 1993 


\section{BNL ALARA Center Data Base}

U.S.A.

\section{BWR/5 FULL-SYSTEM DECONTAMINATION FEASIBILITY}

\section{STUDY}

Keywords: CONTAMINATION REMOVAL; FULL SYSTEM

DECONTAMINATION; DECONTAMINATION; RADIATION FIELD

CONTROL

\section{Principal Investigator:}

\section{T.A. Beaman}

Niagara Technical Consultants

628 Twenty-eighth Street

Niagara Falls, NY 14301

U.S.A.

\author{
Project Manager: \\ C. Wood \\ Electric Power Research Institute \\ P.O. Box 10412 \\ Palo Alto, CA 94303 \\ U.S.A
}

Phone: (415)855-2379

Objectives: To determine the engineering feasibility and cost-effectiveness of complete reactor system decontamination of a BWR/5 plant using the LOMI process.

Comments: The EPRI report TR-100049 concluded that BWR full-system decontamination was technically and economically feasible on a BWR/3 plant design. EPRI conducted another FSD study on a BWR $/ 5$ plant because of several design differences compared with the BWR/3. The approach was to determine the applicability of decontamination studies at Commonwealth Edison Company's Quad Cities BWR/3 to its LaSalle County BWR/5.

Remarks/Potential for dose limitation: The conclusions are:

1) Full System Decontamination of the BWR/5 at LaSalle would require approximately $30 \%$ less reagent and ion-exchange resins compared with the BWR $/ 3$.

2) No new, untested materials would be exposed to the decontamination solvent.

3) Only minor changes would occur in the proposed operation of BWR systems during the decontamination, with less decontamination equipment required.

4) Estimated costs and benefits would be similar to the BWR/3 (\$7.8 million cost, $\$ 12.6$ million benefit).

5) Exposures during the decontaminations would increase slightly (54 vs 42 rem).

References: "BWrR/5 Full-System Decontamination Feasibility Study", EPRI TR-102332 Final Report, May 31, 1993.

Duration: from: 1991 to: 1993

Funding:

Status: Completed

Last Update: August 19, 1993 


\section{MOVING FROM ULTRA-PURE BWR WATER TO PLANT-TAILORED WATER CHEMISTRY}

Keywords: CONTAMINATION PREVENTION; WATER CHEMISTRY; PRIMARY COOLANT CHEMISTRY; CORROSION; CORROSION CONTROL; CORROSION PRODUCT; IGSCC; STRESS CORROSION CRACKING; HYDROGEN WATER CHEMISTRY; OXYGEN CONTENT

Principal Investigator:

Project Manager:

\section{P. Fejes}

ABB Atom AB

S-721 63 VÄSTERAS

SWEDEN

Phone: +4621347504

Objectives: Determine the impact of chemistry on activity build-up and on materials behaviour.

Comments: The study investigated whether material corrosion can be reduced in Swedish BWRs by controlling the water chemistry are described. Some of the topics covered include:

- Problem with the behaviour of copper corrosion products in the reactor core

- Combating pipe cracking by adjusting the concentration of dissolved ixyger 1 in the main recirculation water

- Cobalt reduction by controlling the iron-nickei concentration ratio and by zinc addition

- Dealing with sulphate and chloride, which have a strong enhancing effect on IGSCC, in the reactor water

- Hydrogen Water Chemistry

- $\mathrm{pH}$ adjustment by addition of alkali metal hydroxides to the reactor water

- Condensate clean-up system related aspects

Remarks/Potential for dose limitation: The water chemistry activities still aim at achieving low radioactive contamination of the reactor systems; control of identified harmful chemical compounds in the process waters; and reduction of radioactive wastes. The way to improvements routes via better information and profound understanding of the fundamental scientific background of operating experiences.

References: Fejes, P. "Moving From Ultra-Pure BWR Water to Plant-Tailored Water Chemistry," Water Chemistry of Nuclear Reactor Systems 6, Vol. 2, pp. 90-95, British Nuclear Energy Society, London, 1992.

Duration: from: 1991 to: 1992 Funding: N/A

Status: Completed Last Update: September 13, 1993 


\section{EFFECTS OF PH OF PRIMARY COOLANT ON PWR CONTAMINATION}

Keywords: CONTAMINATION PREVENTION; WATER CHEMISTRY; PRIMARY COOLANT CHEMISTRY; COOLANT; PH; PH CONTROL; DOSE

RATE

Principal Investigator:

S. Anthoni

CEA-CEN Cadarache

13108 St. Paul lez Durance Cedex

FRANCE

Phone: 0113342257954
Project Manager:

Objectives: Investigate the effects of increasing $\mathrm{pH}(300)=7.0$ to $\mathrm{pH}(300)=7.2$ on six $900 \mathrm{MWe}$ French PWRs.

Comments: Basic research has converged on an optimum pH lying between 7.2 and 7.4 with little difference between the two $\mathrm{pH}$ values. Thus, tests on six $900 \mathrm{MWe}$ reactors were started in 1987 by increasing the Lithium concentration to obtain a $\mathrm{pH}(300)$ of 7.2. A systematic program for measuring the dose-rate around the primary piping of the reactors was set up. Each time there was a refueling shutdown, dose rate measurements were taken around the primary piping.

Two approaches to analysis were taken: 1) Comparing contamination in two groups of reactors with different chemical conditioning of the primary water. 2) Comparing the development of reactor contamination before and after changing the conditioning.

Remarks/Potential for dose limitation: The comparison in the two groups of reactors was inconclusive. The mean dose rate index for $\mathrm{pH}=7.0$ was $59(\mathrm{mRem} / \mathrm{H})$ with a standard deviation of 19. For $\mathrm{pH}=7.2$, it was 66 with SD of 21 . The results were similarly inconclusive when comparing each reactor before and after changing the $\mathrm{pH}$. Tests carried out on French EdF reactors did not reveal a significant impact due to changing primary coolant conditions to give a value greater than 7.0. But they did not contradict the tendencies revealed by the basic research. However, the effect of changing the $\mathrm{pH}$ is slight when compared with changes in design such as the composition of fuel assembly grids or steam generator production techniques.

References: Anthoni, S., Ridoux, P., Menet, O. and Weber, C., "Effects of pH of Primary Coolant on PWR Contamination," Water Chemistry of Nuclear Reactor Systems 6, Vol. 2, pp. 9-15, British Nuclear Energy Society, London, 1992.

Duration: from: 1987 to: 1993

Funding: N/A

Status: In progress

Last Update: September 14, 1993 


\section{BEHAVIOR OF PWRs IN SPAIN FOLLOWING CHANGES TO MODIFIED CHEMISTRY AND FUEL SPECIFICATIONS}

\section{Keywords: CONTAMINATION PREVENTION; PRIMARY COOLANT CHEMISTRY; WATER CHEMISTRY; PH; PH CONTROL; COBALT; RADIATION FIELD CONTROL}

\section{Principal Investigator:}

\section{Project Manager:}

E. Fernandez Lillo

Vandellos NPP

Vandellos, Tarragona

SPAIN

Phone: +34 77810011

Objectives: Determine the impact on radiation fields at the large Spanish PWR plants of Asco 1\&2, Almaraz 1\&2, Trillo and specially Vandellos 2 from primary coolant chemistry control and fuel grid material replacement.

Comments: The main areas of the work presented include:

- Tight follow up of coolant chemistry and radiochemistry.

- Gamma spectrometry of the system surfaces.

\section{Remarks/Potential for dose limitation:}

- Three factors were found to contribute to system surfaces activation: 1) Cobalt impurity and Nickel content in plant materials, 2) Operating chemistry, 3) Cobalt ingress due to maintenance operations

- The optimum pH(T avg) for Vandellos 2 is just below 7.4

- Different response of $\mathrm{Co}-58$ with respect to $\mathrm{Co}-60$ and Fe-59 to $\mathrm{pH}$ changes suggests different source oxide in the core for them.

- There may be different optimum pH values for different radioisotopes.

- Trillo low radiation fields are related to both Co-58 and Co-60 activity.

- The high Co-60 activity in Almaraz 1 and Vandellos 2 is probably due to high Cobalt input from old specification fuel element grids and valve lapping respectively.

- The reduction of radiation fields in Almaraz 2 and Asco 1 and 2 has been due to adoption of the elevated $\mathrm{pH}$ chemistry and the fuel substitution by low Cobalt impurity at Almaraz and Zircaloy grids at Asco.

References: Fernandez Lillo, E., Boronat, M., Cascante, C., Adrada, J. and Ortega, A., "Behaviour of PWRs in Spain Following Changes to Modified Chemistry and Fuel Specifications," Water Chemistry of Nuclear Reactor Systems 6, Vol. 2, pp. 24-30, British Nuclear Energy Society, London, 1992.

Duration: from: 19 to: 1993 Funding: N/A

Status: In progress Last Update: September 15, 1993 


\title{
REVIEW OF EFFECT OF LITHIUM ON PWR FUEL CLADDING CORROSION
}

\section{Keywords: COMPONENT RELIABILITY; FUEL CLADDING; ZIRCALOY; CORROSION; LITHIUM; WATER CHEMISTRY; PRIMARY COOLANT CHEMISTRY; OXIDE FILM}

\section{Principal Investigator:}

\author{
Project Manager:
}

\section{Polley}

Nuclear Electric

Berkeley Technology Centre

Berkeley, Gloucester GL13 9PB

U.K.

Phone: 44(UK)-453-812174

Objectives: Review the reactor corrosion data on Zircaloy-4 which is currently available and to place this within the context of expectations derived from laboratory tests in an attempt to assess whether reactor corrosion rates are enhanced by operating an elevated-lithium regime.

\section{Comments:}

Laboratory Experience:

- Early isothermal tests showed that LiOH additions resulted in an increase in the rate of Zircaloy corrosion, especially in the post-transition region.

- Recent isothermal autoclave tests show that the deleterious influence of lithium additions is ameliorated even at quite low concentrations of boric acid.

- Tests done under boiling conditions indicate that realistic concentrations of boron can ameliorate the effects of high concentrations of lithium, even though boiling concentrates the lithium at the oxide surface

Experience From Reactors Operating Under Elevated-Lithium Regimes:

- Millstone Point 3: somewhat higher corrosion rates

- Ringhals: no significant enhancement in oxide thickness

- St. Lucie 1: seem to show a faster increase in corrosion rate

- Calvert Cliffs: no significant enhancement in corrosion rates

- The Halden In-Pile Loop: little effect on enhancing corrosion rates

Remarks/Potential for dose limitation: The reactor experience summarized show that NO gross deterioration in Zircaloy corrosion behaviour has been found from operation under elevated-lithium conditions. In cases where there seem to be lithium enhanced corrosion rates, more studies need to be done to ascertain whether the increased rates are due to high lithium concentration or some other cause.

References: Polley, M.V. and Evans, H.E., "Review of Effect of Lithium on PWR Fuel Cladding Corrosion," Water Chemistry of Nuclear Reactor Systems 6, Vol. 2, pp. 61-66, British Nuclear Energy Society, London, 1992.

Duration: from: 1991 to: 1992 Funding: N/A

Status: Completed 


\section{SHUTDOWN CHEMISTRY IN SPANISH PLANTS}

\section{Keywords: OPERATIONAL AND MAINTENANCE TECHNIQUES; SHUTDOWN CHEMISTRY; OUTAGE TIME; DOSE RATE; BORATION}

\section{Principal Investigator:}

R. Llovet

Westinghouse Electric Corporation

Agustin PE Foxa 29

28036 Madrid

SPAIN

Phone: 3231443

\section{Project Manager:}

E. Fernandez Lillo

Vandellos NPP

Vandellos

Tarragona

SPAIN

Phone: + +3477810011

Objectives: Investigate shutdown procedure improvements implemented in Westinghouse designed Spanish PWRs in the areas of reduced critical path time, in-core and ex-core activated corrosion products solubilization and reactor coolant system radiation measurements.

Cumments: Since 1986 the five large Spanish Westinghouse PWR plants have instituted a series of modifications to the refueling shutdown procedures that have achieved significant time optimization and potential benefits in terms of ex-core activity reduction. These changes were:

- Boration to refueling shutdown concentration prior to cooldown.

- Use of a new charge of resin in the Chemical and Volume Control System mixed bed: demineralizer in the $\mathrm{H}^{+} / \mathrm{OH}^{-}$form for coolant purification during shutdown.

- Reactor Coolant System draindown as soon as the Co-58 peak in solubility has been confirmed, with a coincident hydrogen peroxide residual, and has been observed to be undergoing reduction by ion-exchange purification.

- Out-of-core radiation fields are believed to be reduced by application of this optimized procedure in several plants. Calculations performed at Vandellos 2 during the 2 nd refueling shutdown yield an estimate of $20 \%$ reduction.

- Critical path time for the refueling outages has been reduced significantly. Calculations at Asco 2 2nd refueling indicated times savings about 2.5 days.

Remarks/Potential for dose limitation: This evaluation has demonstrated the benefit in terms of dose rate reduction of establishing acid-reducing environments and maintaining them for certain time periods prior to establishing acid-oxidizing chemistry.

References: Llovet, R., Kormuth, J.W., Fernandez Lillo, E., Boronat, M., Ortega, A., "Shutdown Chemistry in Spanish Plants," Water Chemistry of Nuclear Reactor Systems 6, Vol. 2, pp. 67-73, British Nuclear Energy Society, London, 1992.

Duration: from: 1986 to: 1992 Funding: N/A

Status: Completed

Last Update: September 16, 1993 
EFFECT OF SURFACE TREATMENT ON RADIOACTIVITY DEPOSITION ON STAINLESS STEEL COUPONS EXPOSED IN DOEL 2

Keywords: CONTAMINATION PREVENTION; COMPONENT RELIABILITY; PRECONDITIONING; SURFACE PREPARATION; SURFACE TREATMENT; SURFACE CONDITIONING; STAINLESS STEEL; CHROMIUM; PALLADIUM COATING; ELECTROPOLISHING; PASSIVATION

\section{Principal Investigator:}

Project Manager:

\section{Pick}

Nuclear Electric plc

Timpson Road

Wythenshawe, Manchester M23 9LL

U.K.

Phone: +44619464202

Objectives: Present the results of a joint LABORELEC-EBES/Nuclear Electric/EPRI study of surface pre-conditioning and coatings to reduce radioactivity uptake on surfaces undertaken on the Doel 2 PWR in Belgium.

Comments: Stainless steel 304L, 309L, 316L and CF8M coupons have been exposed for between one and three cycles in the hot and cold legs of a steam generator channel head on Doel 2 PWR between 1966 and 1991. In the present paper results from examination of coupons exposed up to 1991 during Cycles 14, 15 and 16 are reported. The surface finishes on these coupons included as received, electropolished, electropolished/passivated, chromium plated, chromium plated/passivated and palladium coated. Results from gamma spectrometry and scanning electron microscopy examinations of the coupons are reported. The most dramatic result is the very low activity uptake on the chromium plated coupons.

Remarks/Potential for dose limitation: Occupational radiation exposure arises principally from exposure to radiation fields on out-of-core surfaces during maintenance and inspection operations. Reduction of these radiation fields by treatment of surfaces is in the interest of ALARA.

The main conclusions from this study are:

- Chromium plated coupons showed an order of magnitude lower levels of activity than as received coupons.

- The activity levels of the 309L, 316L and CF8M chromium plated coupons were very similar.

- The addition of a passivation stage after the chromium plating treatment had a detrimental effect by increasing activity uptake by up to a factor of two.

- Electropolished/passivated (E/P) CF8M coupons have a factor of 2 lower activity while E/P 309L coupons have a slightly increased level of activity uptake compared 


\section{BNL ALARA Center Data Base}

BELGIUM

R-385

with the as received coupons.

- After over 3 Cycles of exposure, the palladium coatings yielded no clear reduction of Co-58 and Co-60 uptake and enhanced uptake of Cr-51, Ag-110m, Sn-113 and Sb-125.

References: Pick, M.E., Young, M.A. and Roofthooft, R., "Effect of Surface Treatment on Radioactivity Deposition on Stainless Steel Coupons Exposed in Doel 2," Water Chemistry of Nuclear Reactor Systems 6, Vol. 2, pp. 74-79, British Nuclear Energy Society, London, 1992.

Duration: from: 1986 to: 1992

Status: Completed
Funding: N/A

Last Update: September 16, 1993 


\section{UTILITY APPROACH TO RADIATION FIELD REDUCTION BY COOLANT CHEMISTRY CONTROL}

Keywords: CONTAMINATION PREVENTION; ALARA; PH; PH CONTROL; ZINC INJECTION; WATER CHEMISTRY; PRIMARY COOLANT CHEMISTRY; RADIATION FIELD CONTROL; COBALT REDUCTION; LITHIUM

\section{Principal Investigator:}

\section{Hudson}

Northeast Utilities

P.O. Box 270

Hartford, Connecticut 06141

U.S.A.

Phone: 203-665-3977

\author{
Project Manager:
}

Objectives: Describe the field testing and implementation of zinc injection at Millstone 1 (BWR), and elevated pH control at Millstone 3 (PWR). The results after two cycles of operations are presented.

Comments: In 1986 Northeast Utilities (NU) initiated an aggressive ALARA improvement program for application at all four of its nuclear generating stations. A part of this program was to focus on achieving lower radiation fields by implementing the latest technologies available in coolant chemistry control, cobalt source removal, component surface conditioning and decontamination.

Remarks/Potential for dose limitation: Two cycles of operation with zinc injection at Millstone 1 were successful in reducing surface dose rates by factors up to 2 . The zinc injection process does not seem to introduce any unmanageable concerns, while the expected use of zinc depleted in $\mathrm{Zn}-64$ is likely to improve considerably the benefits of this process. Elevated pH control for two cycles at Millstone 3 has also been successful in controlling the increase of dose rates in SG channel heads and associated piping. Unfortunately, the fuel cladding oxide concerns, possibly enhanced by operation at higher lithium levels, have led to a temporary respite from elevated $\mathrm{pH}$ operations until cladding oxidation limitations are better defined, and/or more corrosion resistant cladding alloys become generally available.

Decontamination, surface treatments and cobalt source removal programs are in place or are being introduced at all of the NU nuclear stations. It is anticipated that these programs, in conjunction with the coolant chemistry programs, will continue to reduce occupational radiation exposure at all of NU's operating reactor units.

References: Hudson, M.J.B. and Klisiewicz, J.W., "Utility Approachy to Radiation Field Reduction by Coolant Chemistry Control," Water Chemistry of Nuclear Reactor Systems 6, Vol. 2, pp. 96-102, British Nuclear Energy Society, London, 1992.
Duration: from: 1986 to: 1992
Funding: N/A
Status: Completed
Last Update: September 17, 1993 


\section{LOW PICOLINATE LOMI - UPDATE}

Keywords: CONTAMINATION REMOVAL; LOMI; DECONTAMINATION; FULL SYSTEM DECONTAMINATION; RADWASTE MINIMIZATION

\section{Principal Investigator:}

Jerry Smee

Niagara Technical Consultants, Inc.

16 Renforth Square

St. Catharines, ONTARIO

CANADA

Phone: 905-937-5454

\section{Project Manager:}

Christopher Wood

Electric Power Research Institute

3412 Hillview Ave., P.O. Box 10412

Palo Alto, CA 94303

U.S.A.

Phone: 415-855-2379

Objectives: Review all aspects of the use of low picolinate LOMI.

Comments: It was observed that the molar ratio of picolinic acid to vanadium employed during full system decontamination (FSD) applications at the Winfrith SGHWR was 3:1. This is 2 times lower than the 6:1 ratio normally used in the U.S. Detail cost-benefit analyses indicated significant financial benefits if the lower ratio could be safely applied in BWR FSD applications.

Theoretical calculations and experimental studies have confirmed that reducing the molar ratio of picolinic acid to vanadium during LOMI decontaminations from 6:1 to 3:1 will have no adverse effects whatsoever on the decontamination itself and will result in significant savings in chemicals, ion exchange resins and costs. No changes to the corrosion behavior of LOMI are expected.

Remarks/Potential for dose limitation: Based on the results of this study, the authors recommend that all future applications of LOMI employ a picolinic to vanadium molar ratio of 3:1 instead of 6:1 or 4.5:1. The advantage is that less chemicals and ion exchange resins are required. This translates to savings of approximately $\$ 236,000$ and $\$ 295,000$ per FSD application in BWRs and PWRs, respectively.

References: Smee, J.L. and Bradbury, D., "Low Picolinate LOMI -Update," Fifth Workshop on Chemical Decontamination, pp. 18.1-18.13, Electric Power Research Institute, Charlotte, North Carolina, 1993.

Duration: from: 1992 to: 1993

Status: Completed
Funding: N/A

Last Update: September 27, 1993 


\section{DECONTAMINATION CHEMISTRY: CURRENT ISSUES}

Keywords: CONTAMINATION REMOVAL; DECONTAMINATION; FULL SYSTEM DECONTAMINATION; CAN-DECON; CAN-DEREM; ALKALINE PERMANGANATE; ZINC ADDITION

\section{Principal Investigator:}

Project Manager:

Robert Speranzini

AECL

System Chemistry and Corrosion Branch

Chalk River Laboratories

Chalk River, ONTARIO K0J 1J0

CANADA

Phone: 613-584-3311

Objectives: Outline the current state of research and experience with the CAN-DECON and CAN-DEREM processes. The issues addressed include: 1) Qualification in the US, 2) AP decomposition and waste generation, 3) Effects of zinc addition.

Comments: The CAN-DEREM process has been qualified for use in PWR full-system decontaminations (FSD) in a major program carried out by Westinghouse in the US. A five step process (CAN-DEREM/AP/CAN-DEREM/AP/CAN-DEREM) was used as the reference case with the CAN-DEREM step applied at $115^{\circ} \mathrm{C}\left(240^{\circ} \mathrm{F}\right)$ for $24 \mathrm{hrs}$ using reagent concentrations of $0.1 \mathrm{wt} \%$. Lower concentrations of reagents and/or fewer steps can be used in order to reduce the volume of resin waste.

For AP/CAN-DEREM applications, examination of the projected ion-exchange resin wastes to be produced during a FSD of a PWR suggests that about 4 times more resin is produced by the AP steps than by the CAN-DEREM steps. In addition, application conditions for AP use have not been optimized, inducing decomposition in some cases.

It was observed that the Co-60 contaminated oxide formed in $\mathrm{Zn}$ containing coolant was easily removed without an AP pretreatment. The implication is significant in that ion-exchange resin wastes from decontamination could be dramatically reduced for PWR plants using $\mathrm{Zn}$ additions since the AP step could be avoided.

Remarks/Potential for dose limitation: To date, 15 CANDU reactor heat-transport-systems (including cores with fuel in place) have been decontaminated with the CAN-DECON process in Canada. In the US, 19 BWR and 5 PWR sub-systems were decontaminated using CAN-DECON. Since 1987, 15 BWR and PWR sub-systems have been decontaminated using the CAN-DEREM process. The decontamination factors for these 2 processes is about 5 to 10 .

References: Speranzini, R.A., Miller, D.G., and Allsop, H.A., "Decontamination Chemistry: Current Issues," Fifth Workshop on Chemical Decontamination, pp. 20.1-20.33, Electric Power Research Institute, Charlotte, North Carolina, 1993.

Duration: from: 1991 to: 1993

Funding: N/A

Status: In progress

Last Update: September 28, 1993 


\section{RESIN OXIDATION PROCESS IMPROVEMENTS}

Keywords: CONTAMINATION REMOVAL; RADWASTE MINIMIZATION; WASTE VOLUME REDUCTION; RESIN OXIDATION

\section{Principal Investigator:}

David Bradbury

Bradtec Ltd.

The University of the West of England Coldharbour Lane, BRISTOL BS16 1QY

U.K.

Phone: 0272763937
Project Manager:

C. Wood

Electric Power Research Institute

P.O. Box 10412

Palo Alto, CA 94303

U.S.A.

Phone: 415-855-2379

Objectives: Investigate improvements in the Resin Oxidation Process. This is a method developed by EPRI to reduce the volume of ion exchange resin waste arising from reactor decontaminations.

Comments: The resin oxidation process is a low temperature and low pressure wet oxidation process developed primarily for destroying the organic content of ion exchange resins generated at nuclear power plants. The process is designed to be operated by mobile temporary equipment taken to the site where the resin is generated.

The presence of organic materials in radioactive waste can be detrimental to the stability and long term isolation of waste. The resin oxidation process was conceived with the objective of oxidizing the ion exchange resin waste under water at much lower temperatures than incineration. The process also destroys chelants in the resin wastes arising from decontamination operations.

A pilot-scale resin oxidation system was built by $L N$ Technologies and operated at their premises and later at the EPRI NDE Center in Charlotte, NC. Several laboratory tests have been done to verify the process.

Remarks/Potential for dose limitation: This process has the potential to significantly reduce the cost of decontaminations by minimizing the ion exchange resin waste needed to be disposed.

References: Bradbury, D., Elder, G.R., and Kalinauskas, G.L., "Resin Oxidation Process Improvements," FifthWorkshop on Chemical Decontamination, pp. 23.1-23.7, Electric Power Research Institute, Charlotte, North Carolina, 1993.

Duration: from: 1986 to: 1993

Funding: N/A

Status: In progress

Last Update: September 29, 1993 


\section{DEVELOPMENT OF FULL SYSTEM DECONTAMINATION FOR \\ BWRs}

Keywords: CONTAMINATION REMOVAL; DECONTAMINATION; FULL SYSTEM DECONTAMINATION; LOMI; IGSCC; CORROSION; STRESS CORROSION CRACKING; ALKALINE PERMANGANATE

\section{Principal Investigator:}

Barry Gordon GE Nuclear Energy

175 Curtner Ave. MC 785

San Jose, CA 95125

U.S.A.

Phone: 408-925-2558

\author{
Project Manager: \\ Chris Wood \\ Electric Power Research Institute \\ 3412 Hillview Avenue \\ Palo Alto, CA 94303 \\ U.S.A. \\ Phone: 415-855-2379
}

Objectives: Initial evaluation of the feasibility of a full system decontamination (FSD) of a BWR (with fuel removed) using the LOMI process with specific emphasis on:

1) Long term materials compatibility and performance

2) LOMI process review and system interaction/flow paths

3) Radwaste management

4) Recontamination and dose savings

5) Cost benefit analysis

6) Safety review and licensing

Comments: The primary concern with BWR FSD is corrosion of the reactor internals. This report evaluates the applicability of FSD based on:

1) work previously performed to qualify the LOMI process

2) results of LOMI system and subsystem decontaminations

3) experience worldwide of FSD with LOMI

Based on this study, there appears to be no significant corrosion or materials concern for the application of LOMI for BWR FSD. Tests have shown that LOMI neither causes intergranular attack (IGA) or intergranular stress corrosion cracking (IGSCC), nor does it exacerbate existing IGA or IGSCC.

However, the NP-LOMI process is not recommended for FSD use because of some instances of IGA, enhanced crack growth rates, and SCC. The AP-LOMI process appears promising but additional testing is required before it can be considered fully FSD qualified.

\section{Remarks/Potential for dose limitation:}

- The program was successful in qualifying LOMI for BWR FSD with the fuel removed. No BWR plant or fuel material has been identified to be incompatible with LOMI.

- Documentation is now available to utilities for performing a BWR FSD. (EPRI Report TR-100049) 


\section{BNL ALARA Center Data Base}

U.S.A.

- Instead of being a potential risk to reactor internal integrity, FSD may become an integral part of the Optimum Water Chemistry's strategy for SCC minimization.

References: Gordon, B.M., "Topical Report on FSD for BWRs," Fifth Workshop on Chemical Decontamination, pp. 30.1-30.31 Electric Power Research Institute, Charlotte, North Carolina, 1993.

Duration: from: 1989 to: 1993

Funding: $\$ 719,000$

Status: Completed

Last Update: September 29, 1993 


\section{FUEL DECONTAMINATION QUALIFICATION PROGRAM}

\section{Keywords: CONTAMINATION REMOVAL; DECONTAMINATION; FUEL DECONTAMINATION; FULL SYSTEM DECONTAMINATION; FUEL CLADDING; FUEL ASSEMBLY; CORROSION}

\section{Principal Investigator:}

R. Miller

Westinghouse Electric Corporation

P.O. Box 355

Pittsburgh, PA 15230

U.S.A.

Phone: 412-374-2291
Project Manager:

C. Wood

Electric Power Research Institute

P O Box 10412

Palo Alto, CA 94303

U.S.A.

Phone: 415-855-2379

Objectives: Perform a fuel decontamination qualification program at the V.C. Summer site which will qualify full reactor coolant system (RCS) chemical decontamination with fuel in-place while maintaining existing warranties and incorporating improved fuel technologies.

Comments: At the request of South Carolina Electric and Gas Company, Westinghouse in 1989 developed a program to qualify nuclear fuel for full RCS Decon application. This program involved the chemical decontamination of actual fuel assemblies in a specialized canister in the fuel handling building at the V.C. Summer Nuclear Station with the same dilute chemical solvent parameters as were employed in the Full FCS Qualification Program.

Four fuel assemblies were decontaminated: two using CAN-DEREM and two using LOMI. Approximately 20 curies of Co- 58 and Co- 60 were removed from each assembly. The four decontaminated assemblies and two control assemblies were reinserted in the V.C. Summer plant for one more cycle with inspections at the next outage.

Remarks/Potential for dose limitation: Preliminary evaluation of the cladding corrosion oxide thickness measurements on the decontaminated and control assemblies indicates that the decontamination treatments have had no adverse affect on the post decontamination cladding corrosion behavior. However, a number of decontamination process application anomalies were observed. The principal conclusions are:

- The activity level in-core based on prior visual crud deposition and sampling data were underestimated.

- EDTA depletion was observed in the CAN-DEREM reducing step. As a result, the estimated waste volumes for full RCS decon need to be recalculated.

- No detectable quantities of carbon dioxide gas were observed. Thus, $\mathrm{CO}_{2}$ generation is no longer expected to be a problem for full system decon.

- Full plant fuel-in decon should not be limited by fuel cladding corrosion performance.

References: Miller, R.S., Miller, P.E., and Peffer, D.R., "SCE\&G Fuel Decontamination Qualification Program," Fifth Workshop m Chemical Decontamination, pp. 33.1-33.8, Electric Power Research Institute, Charlotte, North Carolina, 1993.

Duration: from: 1989 to: 1993 Funding: N/A

Status: In progress Last Update: September 30, 1993 


\section{PACIFIC NUCLEAR FIELD IMPLEMENTATION}

\section{Keywords: CONTAMINATION REMOVAL; FULL SYSTEM \\ DECONTAMINATION; DECONTAMINATION}

Principal Investigator:

John Sheffield

Pacific Nuclear

One Harbison Way, Suite 209

Columbia, SC 29212

U.S.A.

Phone: 803-781-0426

Objectives: Summarize Pacific Nuclear's scope of work for field implementation of the PWR full reactor coolant system (RCS) decontamination at Consolidated Edison of NY's Indian Point 2 Nuclear Power Station.

Comments: Pacific Nuclear has turnkey responsibility for all engineering, equipment, construction, decontamination processing and waste processing services, including craft labor for implementation of the full RCS decontamination project. The tasks being performed include:

1) Engineering for plant interface modifications

2) Engineering and fabrication of decon process system

3) Development of operating procedures for decon process

4) Construction of plant interface modifications

5) Decon process system testing and installation

6) Tie-in to reactor coolant system

7) Decon implementation (5 step CAN-DEREM/AP process)

8) Waste equipment supply and waste processing

9) Plant restoration and demobilization

Remarks/Potential for dose limitation: A full RCS decontamination final report will be prepared and issued describing the results of the decontamination process and the results of several tests which will be performed as part of the national demonstration of PWR full system decontanination.

References: Sheffield, J., "Pacific Nuclear Field Implementation," Fifth Workshop on Chemical Decontamination, pp. 29.1-29.15, Electric Power Research Institute, Charlotte, North Caroiina, 1993.

Duration: from: 1992 to: 1995

Status: In progress

Funding: N/A

Last Update: October 4, 1993 


\title{
UTILITY DECONTAMINATION EXPERIENCE
}

Keywords: CONTAMINATION REMOVAL; DECONTAMINATION; EMMA Principal Investigator:

\author{
Project Manager:
}

Michel Dupin

Electricite de France

BP 2337420 Avoine

FRANCE

Phone: 3347986715

Objectives: Develop the EMMA decontamination process used in France.

\section{Comments:}

- To apply it on stainless steel, the EMMA process uses 2 cycles: an oxidizing step (15 hrs) and a reducing step ( $5 \mathrm{hrs}$ ) at a temperature of $80^{\circ} \mathrm{C}$.

- The oxidizing solution is a mixture of $\mathrm{KMnO}_{1}(0.1 \% \mathrm{wt})$, nitric acid $(0.013 \% \mathrm{wt})$ and sulfuric acid $(0.005 \% \mathrm{wt})$.

- The reducing solution contains $0.1 \%$ wt ascorbic acid and $0.05 \%$ wt of citric acid.

- When conditions permit, ultrasound is applied during the treatment.

- The process is effective and relatively easy to implement (stable chemical products, operation at atmospheric pressure).

- It has been used since 1989 for the decontamination of primary pump hydraulic systems.

- Dose ràte reduction factor ranges from 6 to 20 .

\section{Remarks/Potential for dose limitation:}

References: Dupin, M., "Utility Decontamination Experience," Fifth Workshop on Chemical Decontamination, pp. 14.1-14.4, Electric Power Research Institute, Charlotte, North Carolina, 1993.

Duration: from: 1989 to: 1993

Funding: N/A

Status: Completed

Last Update: October 6, 1993 


\section{BNL ALARA Center Data Base}

\section{ABB ATOM PROJECT - ALARA 2000}

Keywords: OPERATIONAL AND MAINTENANCE TECHNIQUES;

EXPOSURE REDUCTION; FUEL FAILURE; EVALUATION OF DOSE RATE; NUCLIDE SPECIFIC MEASUREMENT; CORROSION PRODUCT MASSBALANCE

\section{Principal Investigator:}

Tor Ingemansson

ABB Atom AB

S-721 63 Vasteras

SWEDEN

Phone: +0460 21347343

\section{Project Manager:}

Tor Ingemansson

Objectives: To reduce the annual exposures to $50 \%$ of the 1993 level. Three to five parameters that dominate the annual exposure shall be identified. Suggestions to plant specific measures for reducing the dose rates shall be provided to the outages in 1994.

Comments: The project is ordered by TVO, Oskarshamn 1, 2 and 3, Barseback 1 and 2, and Ringhals 1. The motivation for the project are increasing annual exposures. The project is separated into three parts: mapping of the future expected radiological conditions, mass balances of corrosion products, and evaluation of dose rate and nuclide specific in-site measurements.

Remarks/Potential for dose limitation: The effect of fuel failures on the radiation dose rates in a plant will be estimated. Different types of failures will be treated.

References: A presentation of the ABB Atom ALARA projects will be given at the "International Workshop on Implementation of ALARA at Nuclear Power Plants," to be held on Long Island, New York, May 1994. Proceedings will be available from the NRC, the BNL ALARA Center, and the National Technical Information Center after the workshop.

Duration: from: 1993 to: 1995

Funding: 2.5 py

Status: In progress

Last Update: December 9, 1993 


\section{DEVELOPMENT AND USE OF AN IN-PILE LOOP FOR BWR CHEMISTRY STUDIES}

\section{Keywords: CONTAMINATION PREVENTION; COMPONENT RELIABILITY; WATER CHEMISTRY; NITROGEN-16; ELECTROCHEMICAL POTENTIALS}

Principal Investigator:

MIT Nuclear Reactor Laboratory

\section{Project Manager:}

R. Pathania

Electric Power Research Institute

P.O. Box 10412

Palo Alto, CA 94303

U.S.A.

Phone: 415-855-2411

Objectives: Measure and evaluate changes in radiolysis product generation as well as electrochemical corrosion potential (ECP) levels and nitrogen-16 (N-16) behavior as a function of BWR core coolant inlet water chemistry.

Comments: An in-pile loop has been successfully constructed and operated to simulate BWR coolant chemistry conditions. Results from a series of runs demonstrated the effects of a wide variety of organic and inorganic chemical additions on radiolysis product generation, $\mathrm{N}-16$ behavior, and ECP. These results were consistent with similar measurements in the reactor coolant of full-scale BWRs, providing data useful in building more reliable predictive models to explain actual plant experience.

Water radiolysis products, such as oxygen and hydrogen peroxide, and their effect on ECP play an important role in the stress corrosion cracking of reactor plant materials and the behavior of important species such as N-16. The purpose of this study was to obtain quantitative cause and effect data important to the evaluation of BWR chemistry conditions, both inside and outside current guideline values.

Remarks/Potential for dose limitation: The observed effects of changing from normal water chemistry to hydrogen water chemistry included reduced oxygen and hydrogen peroxide concentrations, more negative ECPs, and increased N-16 carry-over in the steam phase. Organic additives and hydrogen had similar effects, increasing $\mathrm{N}$-16 steam phase activity by a factor of approximately five while lowering ECP to levels that protect against stress corrosion cracking (below $-230 \mathrm{mV}$ ). However, measured concentrations of $\mathrm{O}_{2}, \mathrm{H}_{2}$, and $\mathrm{H}_{2} \mathrm{O}_{2}$ were higher by a factor of two or more than those calculated using the MIT radiolysis code. This result is of potential significance for peroxide generation where BWR plant data are lacking. Molybdate was identified as a promising additive, capable of significantly lowering ECP without increasing $\mathrm{N}-16$ carry-over. Improvements were identified for future runs to measure $\mathrm{H}_{2} \mathrm{O}_{2}$ and determine ECP more accurately.

References: "Development and Use of an In-Pile Loop for BWR Chemistry Studies," EPRI TR-102248 Final Report, Electric Power Research Institute, Palo Alto, CA, September 1993.
Duration: from: 1992 to: 1993
Funding: N/A

Status: Completed

Last Update: December 13, 1993 


\section{REPLACEMENT OF PINS \& ROLLERS IN IRRADIATED BWR CONTROL BLADES}

Keywords: REMOTE SYSTEMS; PINS AND ROLLERS; COBALT REDUCTION

\section{Principal Investigator:}

Christian Ruoss and Norman Stolzenberg

ABB Combustion Engineering

1000 Prospect Hill Road

Windsor, CT 06095-0500

U.S.A.

Phone: 203-688-2400

\author{
Project Manager: \\ Howard Ocken \\ Electric Power Research Institute \\ P.O. Box 10412 \\ Palo Alto, CA 94303 \\ U.S.A.
}

Phone: 415-855-2055

Objectives: Design, fabricate, and demonstrate remotely operated equipment that could be used in the spent-fuel pool at BWR sites and would remove the upper pins and rollers in irradiated control blades, replacing them with stainless steel buttons.

Comments: Equipment was designed and tested on unirradiated control blades at ABB Combustion Engineering's facility in Windsor, Connecticut. Modifications were made to accommodate various control blade designs, and the system was then tested at Commonwealth Edison Company's LaSalle Station.

The equipment uses electrical discharge machining (EDM) to remove the upper roller, most of the pin, and a small portion of the control blade. All cut material is collected in a waste container. Fine dust from the EDM operation is collected on a filter. The cut surface is brushed, finished, and inspected. Two stainless steel button halves are remotely installed and riveted together. Their installation is checked with a torque test. A test on unirradiated control blades led to minor modifications to the equipment and was followed by a test on an irradiated control blade at the LaSalle Station.

Remarks/Potential for dose limitation: The release of cobalt from the pins and rollers has been calculated to be responsible for up to $40 \%$ of shutdown radiation fields. Thus, a strong incentive exists to develop equipment capable of removing this significant cobalt inventory. Computer simulations has shown the possibility of a $20 \%$ to $40 \%$ field reduction.

\section{References:}

"Replacement of Pins and Rollers in Irradiated BWR Control Blades," EPRI TR-101837s Vol. 1, Electric Power Research Institute, Palo Alto, CA, February 1993.

Ruoss, C., "Replacement of Pins \& Rollers in Irradiated BWR Control Blades," Radiation Field Control Seminar, Electric Power Research Institute, Seattle, Washington, 1993.

Duration: from: 1991 to: 1993

Status: In progress

$$
\text { Funding: N/A }
$$

Last Update: March 18, 1994 


\section{COBALT SOURCE REDUCTION - CONTROL ROD PIN \& ROLLER REPLACEMENT}

Keywords: COMPONENT RELIABILITY; COBALT REDUCTION; PINS AND ROLLERS; CONTROL ROD

\section{Principal Investigator:}

J. Cearley

GE Nuclear Energy

175 Curtner Ave.

San Jose, CA 95125

U.S.A.

Phone: 408-925-2394

Objectives: Describe the General Electric program for replacing the irradiated control rod pins \& rollers as a mean of reducing cobalt sources from the reactor core.

Comments:

Design:

- No EDM or welding

- Use spacer pads

- Top pins \& rollers only

- Minimize implementation time

Process:

- Remove roller with hydraulic punch

- Install posi-lock spacer pad

Design of Spacer Pads:

- Two piece self locking device

- Primary retention: 7/16 inch thread

- Secondary retention: snap ring

- Material: inconel X-750 (same as current rollers)

Attributes of Spacer Pads:

- Positive self-locking device

- Retains pin segments

- Minimizes primary water circulation around pin segments

- Sized to be compatible with standard and GE 10 channels

Remarks/Potential for dose limitation:

Advantages:

- Eliminates majority of Co source

- Minimizes risk of damage to CR

- Minimizes risk of pool contamination

- Minimizes amount of waste: no EDM Swarf

- Simple/fast process

- Minimum effect on pool space 


\section{BNL ALARA Center Data Base}

U.S.A.

Status of program:

- BWR 2-4 (D-lattice) spacer pad complete

- Spacer pad qualification testing completed

- Spacer pad safety evaluation complete

- BWR 2-4 (D-lattice) tooling design and qualification complete

- Site demonstration successfully completed at KKM - March 1993

- C-lattice tooling design and qualification in progress

- Initial production at KKM August 1993

References: Cearley, J.E., "Cobalt Source Reduction - Control Rod Piul \& Roller Replacement," Radiation Field Control Seminar, Electric Power Research Institute, Seattle, Washington, 1993.

Duration: from: 1992 to: 1993

Funding: N/A

Status: In progress

Last Update: January 3, 1994 


\section{PERFORMANCE OF IRON-BASE HARDFACING ALLOYS IN GATE VALVES TESTED UNDER SIMULATED BWR CHEMISTRY CONDITIONS}

Keywords: COMPONENT RELIABILITY; HARDFACING ALLOYS; EVERIT 50; NOREM; STELLITE; COBALT REDUCTION; MATERIALS

\section{Principal Investigator:}

E. Murphy

Atomic Energy of Canada, Ltd.

Sheridan Park Research Community

Mississauga, ONTARIO L5K 1B2

CANADA

Phone:

\author{
Project Manager: \\ Howard Ocken \\ Electric Power Research Institute \\ P.O. Box 10412 \\ Palo Alto, CA 94303 \\ U.S.A. \\ Phone: 415-855-2055
}

Objectives: Determine the behavior of several hardfacing alloys under autoclave BWR conditions.

\section{Comments:}

1) Both the PWR and the BWR phases of the valve hard facing testing program are completed.

2) The testing program has demonstrated the welding practicality of the alloys based on deposit hardness and chemical composition.

3) All alloys tested in the BWR phase had zero cold and hot leakage, with the exception of the valve with NOREM 04 which showed a persistent hot leakage. However, based on the various examinations it was concluded the hot leakage was the result of a fit-up problem rather than a deficiency of the deposit.

4) All alloys tested had similar resistance to sliding wear damage and galling which was comparable to that of the STELLITE 6 control standard.

5) With the exception of EB 5183, the candidate alloys had equal or superior corrosion resistance to STELLITE 6. EB 5183, however, was susceptible to pitting attack and therefore not suitable for applications in BWR primary circuits.

6) EVERIT 50, NOREM 01, and NOREM 04 meet or surpass the performance of the STELLITE 6 standard with respect to corrosion and material loss due to wear and maintenance of the valves sealing function. They have met the acceptance criterion established for this program and can be considered to be acceptable alternatives to STELLITE 6 for BWR valve hardfacing applications.

\section{Remarks/Potential for dose limitation:}

References: Murphy, E.V. and Inglis, I., "Performance of Iron-Base Hardfacing Alloys in Gate Valves Tested Under Simulated BWR Chemistry Conditions," Radiation Field Control Seminar, Electric Power Research Institute, Seattle, Washington, 1993.

Duration: from: 1992 to: 1993 Funding: N/A

Status: Completed

Last Update: January 4, 1994 

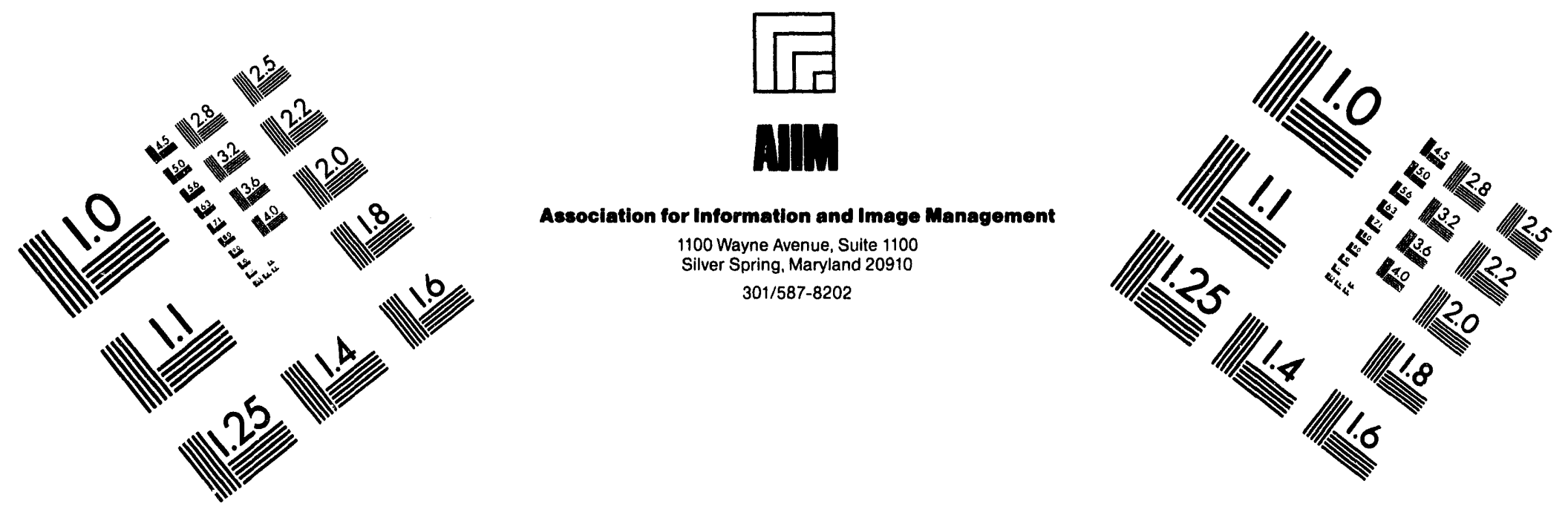

\section{Centimeter}

$\begin{array}{llllllllllllllll}1 & 2 & 3 & 4 & 5 & 6 & 7 & 8 & 9 & 10 & 11 & 12 & 13 & 14 & 15 & \mathrm{~mm}\end{array}$

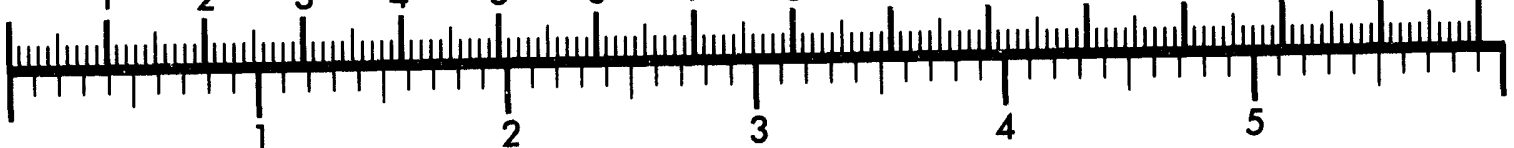

Inches
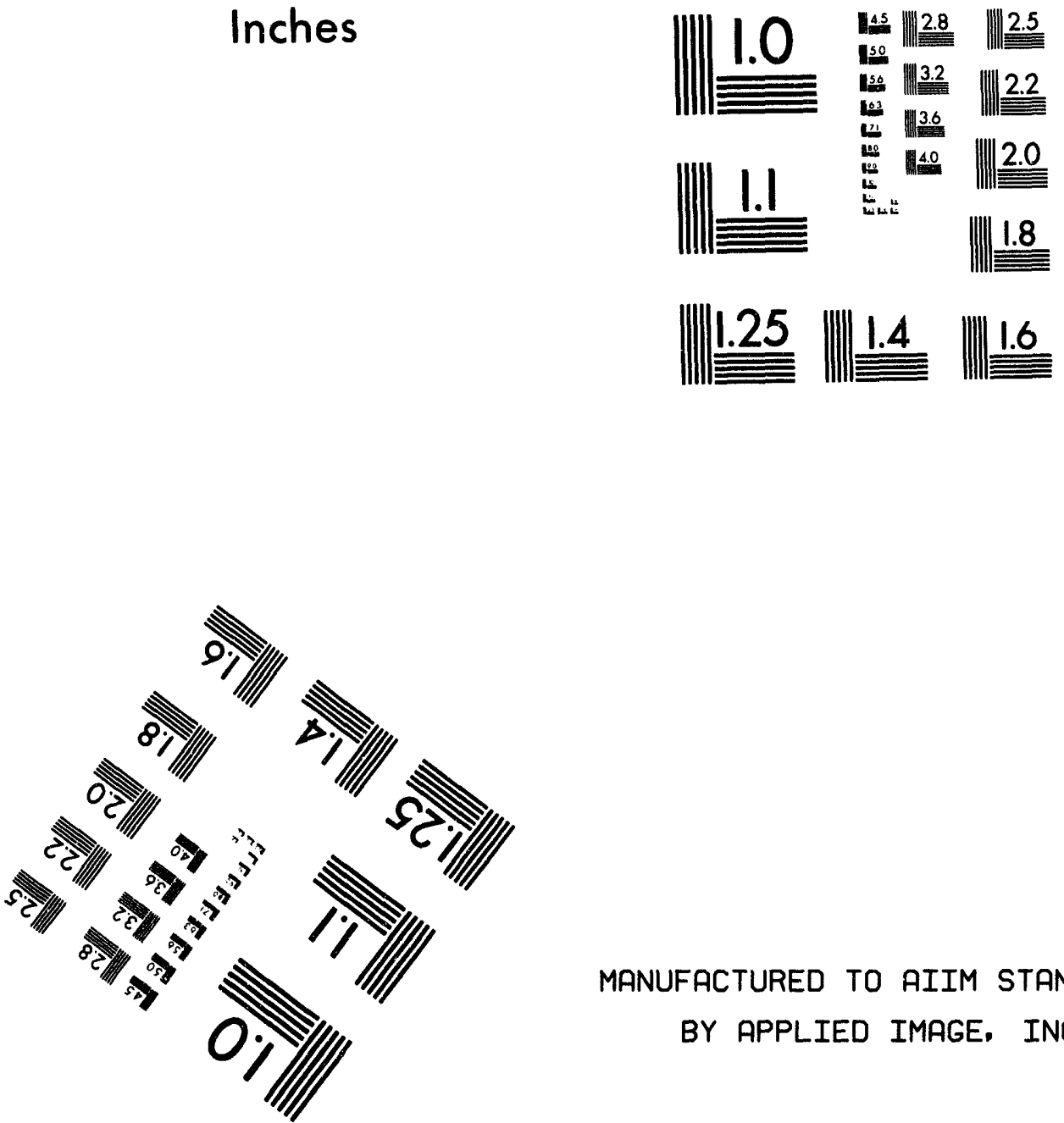

MANUFACTURED TO AIIM STANDARDS

BY APPLIED IMAGE, INC.

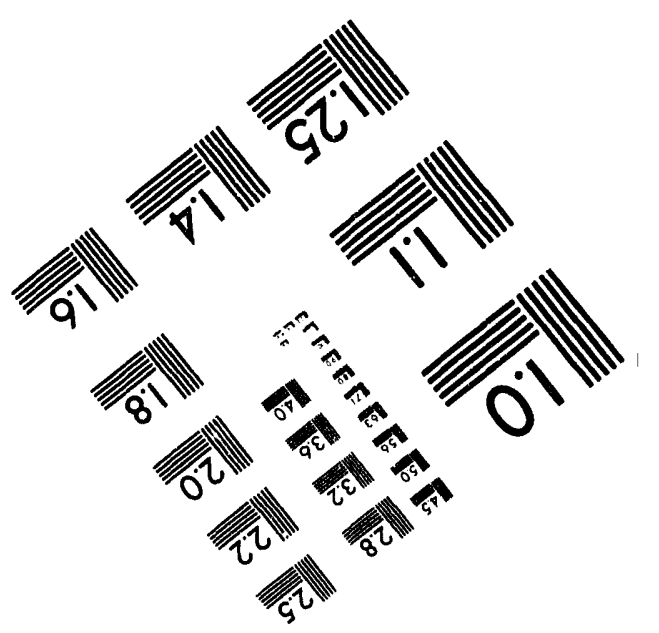



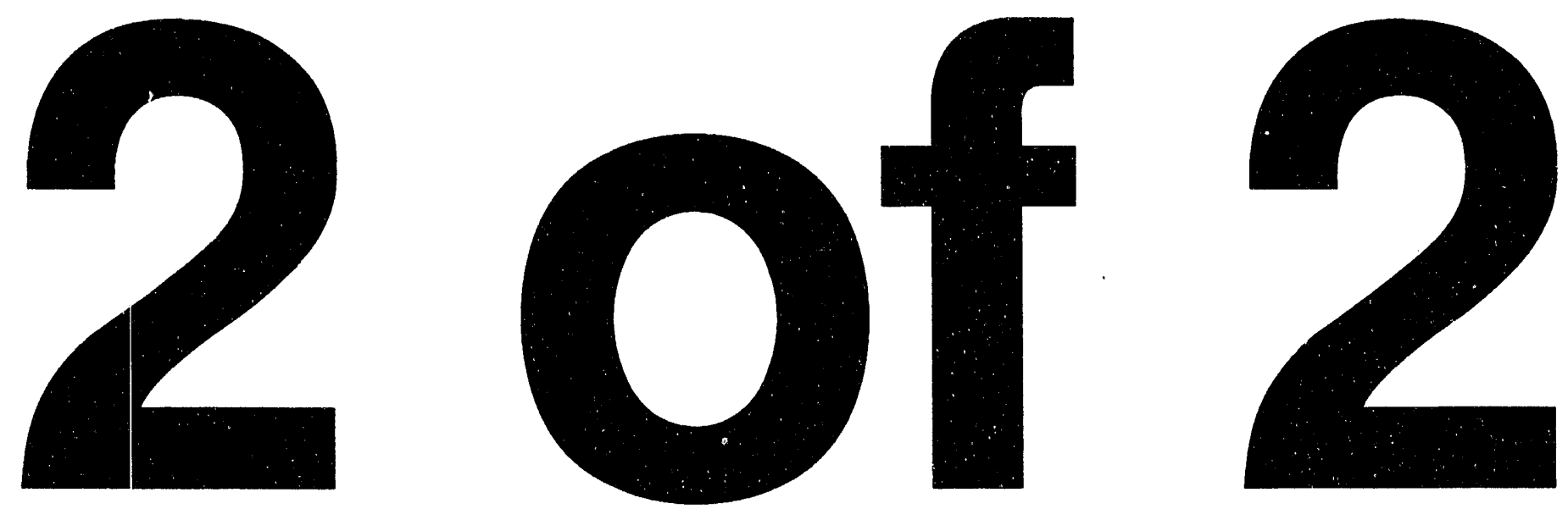


\section{NOREM WEAR-RESISTANT ALLOYS: AN EPRI PROGRAM UPDATE}

\section{Keywords: COMPONENT RELIABILITY; NOREM; WEAR-RESISTANT} ALLOY; HARDFACING ALLOY; COBALT REDUCTION

\section{Principal Investigator:}

Michael Phillips

EPRI NDE Center

1300 Harris Blvd

Charlotte, NC 28262

U.S.A.

Phone: 704-547-6082

\section{Project Manager:}

Howard Ocken

Electric Power Research Institute

P.O. Box 10412

Palo Alto, CA 94303

U.S.A.

Phone: 415-855-2055

\section{Objectives:}

1) Reduce major source of background radiation

2) Provide utilities with a cobalt-free hardfacing alloy which exhibits wear \& corrosion properties equivalent to Alloy 6

3) Develop welding product forms suitable for in-situ application

\section{Comments:}

Existing NOREM Product Forms:

- 0.045 diameter solid \& metal-cored wires for automatic GTAW deposition

- 3/32 \& 1/8 diameter rod for manual GTAW deposition

- gas atomized powder for PTAW \& HIP sintering

NOREM Weldability Program - Project Goals:

- Develop \& successfully deposit NOREM with the GTAW, GMAW, \& FCAW processes

- Demonstrate multi-layer crack-free welds on carbon steel \& stainless steel substrates which yield wear properties equal to Stellite 6

- Develop welding parameters which require no preheat

- Demonstrate a localized repair employing NOREM

NOREM GTA Weldability (B1) Current Status:

- Successfully demonstrated on stainless steel at ambient temperature

- Successfully demonstrated on wrought carbon steel with 309 Butter and with $200^{\circ} \mathrm{F}$ preheat

- Successfully demonstrated repairs on SS \& CS with $200^{\circ} \mathrm{F}$ preheat

\section{Remarks/Potential for dose limitation:}

NOREM PTA Weldability Current Status:

- B1 \& B4 successfully demonstrated on SS at ambient temperature

- B1 \& B4 successfully demonstrated on wrought $C S$ with $800^{\circ} \mathrm{F}$ preheat

- B1 successfully dennonstrated on cast CS with 309 Butter layer and $800^{\circ} \mathrm{F}$ preheat

NOREM Weldability Program 1993 Milestones:

- Develop a chemistry which can be deposited without preheat or a Butter layer on CS with the automatic GTAW process

- Establish utility advisory committee 


\section{BNL ALARA Center Data Base}

U.S.A.

R-399

- Support Dragon Valve \& Union Electric with a "first use" application

- Provide technical support to EPRI membership

- Conduct a NOREM demonstration workshop

References: Phillips, M., "NOREM Wear-resistant Alloys: An EPRI Program Update,"

Radiation Field Control Seminar, Electric Power Research Institute, Seattle, Washington, 1993.

Duration: from: 1992 to: 1995

Funding: N/A

Status: In progress

Last Update: January 4, 1993 


\section{THE EFFECT OF ZINC ON CARBON STEEL AND STAINLESS STEEL IN LITHIATED COOLANT}

Keywords: OPERATIONAL AND MAINTENANCE TECHNIQUES; ZINC ADDITION; WATER CHEMISTRY; CORROSION; ZINC

Principal Investigator:

Project Manager:

Heather Allsop

AECL Research

Station 61

Chalk River, ONTARIO K0J 1J0

CANADA

Phone: 613-584-3311

Objectives: Study the effects of zinc on carbon and stainless steel in a nuclear power plant.

\section{Comments:}

Potential Benefits of Zinc Addition:

- Lower rates of Co- 60 buildup

- lower dose rates; reduced man-rem

- Reduced corrosion rates

- thinner oxides; less ion exchange resin required during a decontamination

- less activity transport

- Decontamination performance

- 410 SS was decontaminated without an oxidizing pretreatment

Comparison With PWR Results - Corrosion Rate Reduction:

Westinghouse (Esposito et al., 1991)

- zinc borate $50 \mathrm{ppb}$

- corrosion rate reduction by factor of

- 3 on 304 and 316 SS

-1.7 to 11 or nickel based alloys

AECL

- corrosion rate reduction by factors of

- 3 on carbon steel

-8 on 410 SS

Remarks/Potential for dose limitation: When 15 to $60 \mathrm{ppb}$ of zinc was added to lithiated coolant:

- Corrosion was reduced by a factor of 3 on carbon steel, and 8 on 410 SS

- Corrosion-product release was reduced by a factor of appro. 18 on both CS and 410 SS

- The affinity for Co-60 was reduced by a factor of 3 to 5 for CS and appro. 60 on 410 SS

- 410 SS was effectively decontaminated using CAN-DECON without an oxidizing pretreatment

- Similar decontamination effectiveness was obtained with CAN-DECON on CS with and without zinc 


\section{BNL ALARA Center Data Base}

CANADA

$\mathbf{R}-\mathbf{4 0 0}$

References: Allsop, H., Godin, M., and Miller, D., "The Effect Of Zinc On Carbon Steel and Stainless Steel In Lithiated Coolant," Radiation Field Control Seminar, Electric Power Research Institute, Seattle, Washington, 1993.

Duration: from: 1992 to: 1993

Funding: N/A

Status: Completed

Last Update: January 4, 1994 


\section{OPTIMUM WATER CHEMISTRY IN RADIATION FIELD BUILDUP CONTROL}

Keywords: OPERATIONAL AND MAINTENANCE TECHNIQUES; WATER CHEMISTRY; ZINC ADDITION; HYDROGEN WATER CHEMISTRY; COBALT REDUCTION

Principal Investigator: Project Manager:

C. C. Lin

General Electric

Vallecitos Nuclear Center

Vallecitos Road

Pleaston, CA 94566

U.S.A.

Phone: $415-862-4566$

Objectives: Provide a summary of the latest water chemistry techniques in reducing radiation fields in a BWR.

\section{Comments:}

Countermeasures for Radiation Field Buildup:

- Cobalt source reduction

- Feedwater Fe reduction/control: controlling Co-60 transport

- Ionic impurity reduction: reducing material corrosion

- Depleted zinc oxide (DZO) addition: reducing Co-60 in water

- Decontamination: removing radioactivities on piping

- Prefilming: reducing initial activity buildup

- HWC: reducing material corrosion

Effects of $\mathrm{Zn}$ Addition in Radiation Buildup Control:

- $\mathrm{Zn}$ (depleted in $\mathrm{Zn}-64$ ) is recommended to avoid $\mathrm{Zn}-65$ production

- Lab data confirm that $\mathrm{Zn}$ at 5-10 ppb in water slows down the corrosion rate and reduces Co-60 deposition on steel surface

- Reactor data show $\mathrm{Zn}$ also reduces the Co-60 release rate from fuel deposit, resulting in lower Co-60 concentration in water

Effects of HWC on Radiation Field Buildup:

- Shutdown dose rate increase due to increased Co-60 deposition

- Magnitude of effect different among HWC plants

- Soluble and filterable Co-60 concentrations vary among plants

- Dose rate buildup varies among plants, from none to substantial

- At some plants with both HWC and GEZIP, shutdown dose rate increase was dominated by Zn-65

\section{Remarks/Potential for dose limitation:}

Background:

- Shutdown radiation fields in BWRs have been reduced significantly in recent years, and average personnel exposure continues to decrease slowly 


\section{BNL ALARA Center Data Base}

U.S.A.

- Personnel exposure goals continue to be lowered

- Further reduction in radiation field by water chemistry control is a formidable challenge

- Plant specific strategies aimed at controlling radiation field buildup and minimizing personnel exposure have to be developed and implemented

Summary and Conclusion:

- The concept of optimum water chemistry can be realized in radiation field reduction

- Co/Co-60 model calculation is helpful to define effective approaches to control and reduce radiation field buildup

- Effects of HWC on radiation field buildup have been clearly observed, but the magnitude may be minimized with source term reduction and proper operational procedure

References: Lin, C.C., "Optimum Water Chemistry in Radiation Field Buildup Control," Radiation Field Control Seminar, Electric Power Research Institute, Seattle, Washington, 1993.

Duration: from: 1992 to: 1993

Funding: N/A

Status: Completed

Last Update: January 5, 1994 


\section{STATUS REPORT ON BWR FULL SYSTEM DECONTAMINATION}

Keywords: CONTAMINATION REMOVAL; LOMI; FULL SYSTEM DECONTAMINATION; DECONTAMINATION

Principal Investigator:

Project Manager:

Barry Gordon

GE Nuclear Energy

175 Curtner Ave.

MC 785

San Jose, CA 95125-1014

U.S.A.

Phone: 408-925-2558

Objectives: BWR FSD Program Objective - initial evaluation of the feasibility of a full system decontamination (FSD) of a BWR (with fuel removed) using the LOMI process with specific emphasis on:

1) Long term materials compatibility and performance

2) LOMI process review and system interaction/flow paths

3) Radwaste management

4) Recontamination and dose savings

5) Cost benefit analysis

6) Safety review and licensing

Comments: Summary of Corrosion Data on LOMI, AP/LOMI, and NP/LOMI:

LOMI

- No BWR plant or fuel material has been identified to be incompatible with LOMI

- LOMI does not cause IGA or IGSCC, nor does it exacerbate existing IGA or IGSCC

- LOMI does not effect IGSCC UT detectability

\section{AP/LOMI}

- No crack extension in precracked stainless clad low alloy steel

- No corrosion of irradiated fuel materials

- No IGA or IGSCC in stainless steel or nickel-base alloys

- Cracking/corrosion of $\mathrm{Cr}$ plated parts

- Westinghouse study in AP-LOMI-AP-LOMI at higher temperatures, concentrations, and times:

- IGA on $17-4 \mathrm{pH}$ and type $410 \mathrm{SS}$

- shallow pitting of many alloys

NP/LOMI

- Crack extension in pre-cracked stainless clad low alloy steel

- IGA on welded 316L/321, FS A600 U-bends

- IGA of FS 304

- Enhanced crack growth $(-30 x)$ in SA508-2 


\section{BNL ALARA Center Data Base}

U.S.A.

R-402

Remarks/Potential for dose limitation: GE Nuclear Energy Engineering Positions on LOMI and Oxidation Step Options:

LOMI - The risks associated with the application of LOMI for FSD of BWRs with the fuel removed appears to be very low provided that the process is applied in accordance with the approved process specifications.

AP - The application of AP for FSD of BWRs appears promising. However, additional testing is required before AP can be approved for FSD. For non-FSD applications, AP should be evaluated on a case by case basis.

NP - The application of NP for FSD of BWRs is not acceptable. For non-FSD applications, NP should be evaluated on a case by case basis.

References: Gordon, B.M., "Status Report on BWR Full System Decontamination," Radiation Field Control Seminar, Flectric Power Research Institute, Seattle, Washington, 1993.

Duration: from: 1992 to: 1993

Funding: N/A

Status: Completed

Last Update: January 5, 1994 


\title{
ACTIVITY PICKUP BY COATED COUPONS EXPOSED IN THE DOEL REACTOR
}

\author{
Keywords: CONTAMINATION PREVENTION; SURFACE \\ PRETREATMENTS; SURFACE CONDITIONING; ELECTROPOLISHING; \\ PREFILMING; PREOXIDATION
}

\author{
Principal Investigator: \\ Roger Asay \\ Radiological \& Chemical Technology \\ 1700 Wyatt Drive, Suite 16 \\ Santa Clara, CA 95054 \\ U.S.A.
}

Phone: 408-982-0601

\author{
Project Manager: \\ Howard Ocken \\ Electric Power Research Institute \\ P.O. Box 10412 \\ Palo Alto, CA 94303 \\ U.S.A. \\ Phone: 415-855-2055
}

Objectives: Study various surface pretreatment techniques for reducing out-of-core radiation level buildup.

Comments: Over the past several years, a cooperative program between EPRI and the Belgian utility has been underway to study various surface pretreatment technicues for reducing out-of-core radiation level buildup. The program involves exposure of pretreated coupons made from materials similar to those used in the construction of PWR primary systems. After exposure in the plant for a fuel cycle, the coupons are analyzed to determine the level of deposited activation corrosion products.

Remarks/Potential for dose limitation: Early test results showed a distinct advantage in first electropolishing a surface to reduce true surface area and leave it in a clean, microscopically smooth state. After electropolishing, pre-filming the electropolished surfaces further reduces corrosion and deposition on the surface. Pre-filming methods involved applying thin films of inert materials (e.g., palladium) and pre-oxidation of the base metal itself after electropolishing. The electropolished and preoxidized surface greatly reduces the activity buildup in BWR plants and the initial tests showed similar results in the PWR primary system. The main reason for the corrosion and deposition resistance is believed to be due to the chromium enrichment of the oxide film grown. A technique of first applying a very thin chromium film and then incorporating this chromium into a protective oxide coating pro ed very successful at Doel. Reduction factors in activity buildup of up to 20 were observed. A second test was run wherein only a chromium film was tested (without the pre-oxidation or stabilizing step) which was also very encouraging. The stabilized chromium film has been applied to new coupons for longer term testing at Doel as well as to plant piping for full-scale evaluations.

References: Asay, R.H., "Activity Buildup by Coated Coupons Exposed in the Doel Reactor," Radiation Field Control Seminar, Electric Power Research Institute, Seattle, Washington, 1993.

Duration: from: 1991 to: 1993 Funding: N/A 
LIST OF HEALTH PHYSICS TECHNOLOGY PROJECTS 
H-175 A METHOD FOR OPTIMIZING THE USE OF RESPIRATORY PROTECTION IN RADIATION AREAS

H-176 INDIAN POINT 2 SUB-SYSTEM DECONTAMINATIONS

H-177 NATIONAL DEMONSTRATION OF A FULL RCS CHEMICAL DECONTAMINATION

H-178 PLANT E.I. HATCH CHEMICAL DECON 1991

H-179 CHEMICAL DECONTAMINATION OF THE RESIDUAL HEAT REMOVAL SYSTEM

H-180 ONTARIO HYDRO DECONTAMINATION EXPERIENCE

H-181 RESOURCE MANAGEMENT AS AN ALARA TOOL

H-182 PWR UPPER/LOWER INTERNALS SHIELD

H-183 INTERNAL DOSE, RESPIRATORY PROTECTION AND REVISED 10CFR20 AT DAVIS-BESSE NUCLEAR POWER STATION

H-184 ZION UNIT 2 CYCLE 12 SHUTDOWN AND EARLY BORATION RESULTS

H-185 HEALTH PHYSICS SERVICES ON THE PLATFORM AT SALEM USING ROMMRS

H-186 CHEMICAL DECON OF SYSTEMS: RESULTS AND PROBLEMS

H-187 AN AUTOMATED PROGRAM IMPLEMENTING NEW 10CFR20 REQUIREMENTS AT SOUTHERN NUCLEAR PLANTS

H-188 STEAM GENERATOR REPLACEMENT PROJECT AT NORTH ANNA POWER STATION

H-189 ALARA PROGRAMME MANAGEMENT AND ORGANIZATION IN EDF NUCLEAR POWER STATIONS

H-190 ENHANCED RADIATION WORKER TRAINING AT JAMES A. FITZPATRICK NUCLEAR PLANT 
H-191 S/G REPLACEMENT AT BEZNAU 1: EXPERIENCE AND RESULTS IN RADIOLOGICAL PROTECTION

H-192 PARTNERS IN PERFORMANCE: AN ALARA PERSPECTIVE

H-193 STEAM GENERATOR SNUBBER ELIMINATION

H-194 FUTURE POWER STATIONS IN THE UNITED KINGDOM: DESIGNING FOR LOW DOSES

H-195 A TEAM APPROACH FOR THE MANAGEMENT OF RADIOACTIVE LIQUID EFFLUENTS

H-196 ALARA AND WORK MANIAGEMENT

H-197 RADIOLOGICAL ASSESSMENT OF DECOMMISSIONING AT FORT ST. VRAIN

H-198 PERSONNEL RADIATION EXPOSURE REDUCTION DURING REMOTE STUD HANDLING AT INDIAN POINT 2

H-199 REPLACEMENT OF RWCU PIPING WITH STATE-OF-THE-ART MATERIALS

H-200 EVALUATION OF ZIRCALOY FUEL CLAD OXIDATION AT MILLSTONE 3 PWR

H-201 AN UPDATE ON CHEMISTRY RELATED DOSE REDUCTION EFFORTS AT MILLSTONE NUCLEAR GENERATING STATIONS

H-202 SURFACE CHARACTERIZATION OF THE STEAM GENERATOR CHANNEL HEAD FOLLOWING MECHANICAL/ ELECTROPOLISHING AT MILLSTONE POINT UNIT 2

H-203 CHROMIUM TREATMENT OF RHR PIPING

H-204 ON-LINE MONITORING OF DOSE RATES AND SURFACE ACTIVITY DURING THE CYCLE 17 SHUTDOWN OF RINGHALS 21993

H-205 CORROSION PRODUCTS BEHAVIOR IN FRENCH PRESSURISED WATER REACTOR DURING SHUTDOWN OPERATION

H-206 PWR STARTUP AND SHUTDOWN CHEMISTRY GUIDELINES

H-207 UPDATE ON DOSE RATES IN SIEMENS-DESIGNED PWRS 


\section{Category Index for Health Physics Technology Projects}

COMPONENT RELIABILITY

H191, 193, 200

CONTAMINATION PREVENTION

H194, 201-203, 207-208

CONTAMINATION REMOVAL

H176-180, 186, 195, 197, 199

OPERATIONAL AND MAINTENANCE TECHNIQUES

H175, 181, 183-184, 187-190, 192, 195-196, 201, 204-208

RADIATION SHIELDING

H182

REMOTE SYSTEMS

H185, 198 
Project Manager Index for Health Physics Technology Projects

$\begin{array}{llll}\text { Brown, Roger } & \text { H175 } & \text { Reinhardt, Mike } & \text { H198 } \\ \text { Gettler, Martin } & \text { H188 } & \text { Trovato, S. } & \text { H182 } \\ \text { Hamblin, John } & \text { H190 } & \text { Warren, W. } & \text { H178 } \\ \text { Helmen, Craig } & \text { H192 } & \text { Yagnik, Suresh } & \text { H200 } \\ \text { Ocken, Howard } & \text { H203 } & & \end{array}$


Principal Investigator Index for Health Physics Technology Projects

$\begin{array}{llll}\text { Anthoni, Serge } & \text { H205 } & \text { Parry, John } & \text { H176-177 } \\ \text { Aronsson, Per } & \text { H204 } & \text { Patton, Prince } & \text { H187 } \\ \text { Asay, Roger } & \text { H203 } & \text { Perin, Maurice } & \text { H189 } \\ \text { Bishop, Dave } & \text { H198 } & \text { Perock, John } & \text { H202 } \\ \text { Borst, Ted } & \text { H197 } & \text { Priest, John } & \text { H195 } \\ \text { Brobst, Gary } & \text { H206 } & \text { Reitzner, U. } & \text { H208 } \\ \text { Cruickshank, Herb } & \text { H185 } & \text { Schieber, Caroline } & \text { H196 } \\ \text { Homyk, W. } & \text { H182 } & \text { Schleser, Jim } & \text { H188 } \\ \text { Hudson, Michael } & \text { H201 } & \text { Stern, Scott } & \text { H184 } \\ \text { Kindred, Gerry } & \text { H199 } & \text { Stirzel, Chris } & \text { H193 } \\ \text { Kury, Robert } & \text { H179 } & \text { Swan, Timothy } & \text { H200 } \\ \text { Lacy, C } & \text { H180 } & \text { Warren, W. } & \text { H178 } \\ \text { Marchl, T. } & \text { H207 } & \text { Weidmann, Urs } & \text { H191 } \\ \text { McCarty, John } & \text { H190 } & \text { White, Gary } & \text { H192 } \\ \text { Merwin, S. } & \text { H175 } & \text { Willcock, Alan } & \text { H194 } \\ \text { Miller, Phillip } & \text { H186 } & \text { Zibung, Bruce } & \text { H183 } \\ \text { Palma, Rodrick } & \text { H181 } & & \end{array}$


Sponsor Index for Health Physics Technology Projects

Consolidated Edison Co.

H182

Electric Power Research Institute $\mathrm{H} 203$

New York Power Authority H190

Pacific Gas and Electric H192
Southern Nuclear Operating Company $\mathrm{H} 178$

Virginia Power

H188

Westinghouse Electric Corp H198

Westinghouse Hansford Company

H175 
Battelle-Pacific Northewest L.aboratories H175

Carolina Power and Light Company H179

Centerior Energy Co.

H183, 195

CEPN

H196

Cleveland Electric Illuminating Company H199

Commissariat a L'Energie Atomique $\mathrm{H} 205$

Commonwealth Edison

H184

Consolidated Edison Co.

H176, 177, 182, 198

Electricite de France

H189

GEBCO Engineering, Inc.

H206

New York Power Authority

H190

NOK

H191
Northeast Utilities

H201

Nuclear Electric

H194, 200

Ontario Hydro

H180

Public Service Co. of Colorado

H197

Public Service Electric and Gas H181, 185

Radiological \& Chemical Technology $\mathrm{H} 203$

Siemens AG KWU H207-208

Southern Nuclear Company H187

Southern Nuclear Operating Compæny H178

Vattenfall AB H2O4

Virginia Power H188

Westinghouse Electric Corporation H186, 192, 193, 202 
Subject Index for Health Physics Technology Projects

10CFR20 H187

ALARA H175, 181, 189-190, 192, 196-197

BEZNAU H191

BORATION H184

BRUNSWICK UNIT $1 \quad$ H179

CALLAWAY H193

CAN-DECON H180

CAN-DEREM/AP H176

CANDU H180

CHEMISTRY GUIDELINES H206

CHROMIUM H203

CITROX H179

CITROX/AP H176

COBALT REDUCTION H201

COBALT REMOVAL H176

COOLANT CHEMISTRY H194, 206

CORROSION PRODUCTS H205

COST-BENEFIT ANALYSIS H175

DAVIS-BESSE H183, 195

DECOMMISSION H197

DECONTAMINATION H176-180, 197

DIABI O CANYON PLANT H203

DOSE RATES H204, 207-208

DOSE REDUCTION H194, 196, 198

DOSIMETRY SOFTWARE H187

EDF H189, 196

ELECTROPOLISHING H202

EXTERNAL DOSE H175

FITZPATRICK H190

FORT ST. VRAIN H197

FRENCH PWRS H205

FUEL CLADDING H200

FUEL CYCLE H194
FULL SYSTEM DECONTAMINATION

H177, 180, 186

HATCH UNIT $1 \quad$ H178

HEATER DRAIN H208

INDIAN POINT 2 H176-177, 182, 198

INTERNAL DOSE H175, 183

LIQUID EFFLUENTS H195

MECHANICAL POLISHING H202

MILLSTONE H200, 201, 202

NORTH ANNA H188

PERRY H199

RADIATION PROTECTION H175, 190

RADIOLOGICAL PROTECTION H191

RADWASTE DEPOSAL H195

REACTOR INTERNALS H182

REACTOR VESSEL STUDS H198

REACTOR WATER CLEANUP SYSTEM H199

RECIRCULATION SYSTEM H178

RECONTAMINATION H176

REFUELING H182

REMOTE STUD HANDLING H198

RESIDUAL HEAT REMOVAL SYSTEM

H179, 203

RESOURCE MANAGEMENT H181

RESPIRATORS H175, 183

RESPIRATORY PROTECTION H175, 183

RINGHALS 2 H204

ROBOTICS H185

ROMMRS H185

ROSA H185

SALEM H185

SALEM UNIT 2 H181

SHUTDOWN CHEMISTRY H184, 204-206 
SIEMENS H207-208

SIZEWELL B H194

SNUBBER ELIMINATION H193

SOFTWARE H187

STARTUP CHEMISTRY H206

STEAM GENERATOR H193

ITEAM GENERATOR REPLACEMENT H188, 191

STELLITE H194, 208

STELLITE REDUCTION H207

SUB-SYSTEM DECONTAMINATION

H176, 178-179, 186, 199
SURFACE CONDITIONING H202-203

SURFACE PRETREATMENT H203

TOTAL EFFECTIVE DOSE EQUIVALENT H183

WATER CHEMISTRY H201, 207

WOLF CREEK H193

WORK MANAGEMEN?? H196

WORKER TRAINING $\mathrm{H} 190$

ZINC INJECTION H201

ZION UNIT 2 H184

ZIRCALOY H194, 200 


\section{A METHOD FOR OPTIMIZING THE USE OF RESPIRATORY PROTECTION IN RADIATION AREAS}

\section{Keywords: OPERATIONAL AND MAINTENANCE TECHNIQUES; RESPIRATORS; RESPIRATORY PROTECTION; RADIATION PROTECTION; INTERNAL DOSE; EXTERNAL DOSE; COST-BENEFIT ANALYSIS; ALARA}

\section{Principal Investigator:}

S.E. Merwin, J.B. Martin

Battelle-Pacific Northewest Laboratories

PO Box 999

Richland, WA 99352

U.S.A.

Phone: 509-375-2088

\author{
Project Manager: \\ Roger Brown \\ Westinghouse Hansford Company \\ PO Box 1970 \\ Richland, WA 99352 \\ U.S.A.
}

Phone: 509-376-5101

Objectives: If decisions on the use of respiratory protection equipment are made solely on the basis of airborne radioactivity levels, total dose equivalent (the sum of external and internal exposures) may not be as low as reasonably achievable (ALARA).

The objective of this work was to develop an optimization methodology for deciding when to use respiratory protection equipment. The method should take into account the reduction in worker efficiency that results from the use of respirators (and the increase in external dose equivalent) as well as the costs associated both with using respirators and not using respirators (surveillance, bisassay, record keeping, etc.). It should also allow a range of values to be used for relative worker efficiency and the assumed cost of the detriment of a person-rem.

Comments: The method indicates that the decision on whether to use respirators should be based on the following:

- If the airborne radionuclide concentration is significant with respect to the external dose rate, respirators should generally be worn in order to minimize total effective dose equivalent. The exception is when the cost of wearing respirators is excessive.

- If the external dose rate is significant with respect to the airborne radionuclide concentration, respirators should generally not be worn so that the total effective dose equivalent is minimized. The exception is when wearing respirators significantly reduces administrative and bioassay costs.

- If it is costly to issue respirators, they should not be worn unless the airborne radionuclide concentration is significant with respect to the external dose rate.

- If it is costly to not issue respirators when a potential for inhalation of radioactive material exists, they should be worn unless the external dose rate is significant with respect to the airborne radionuclide concentration.

Remarks/Potential for dose limitation: Work in airborne radioactivity areas often requires the use of respiratory protection equipment. In many cases, the decision to require respiratory protection is based solely on the actual or potential airborne radioactivity concentration. At nuclear facilities in the United States, it is common practice to issue 


\section{BNL ALARA Center Data Base}

U.S.A.

H-175

respiratcrs if airborne radioactivity concentrations exceed specified action levels $(25 \%$ of 10CFR20 Appendix B values) or if surface contamination levels are very high (i.e., potential airborne radioactivity). This practice is based primarily on two factors: (1) current U.S.

Nuclear Regulatory Commission regulations discourage significant internal exposures, and (2) the use of respirators greatly reduces the potential for large accidental intakes. However, this ignores two other important factors that relate to the use of respiratory protection equipment - external radiation levels and the costs of using (or not using) respirators.

References: Merwin, S.E. and J.B. Martin, "A Method for Optimizing the Use of Respiratory Protection in Radiation Areas," Radiation Protection Management, Vol. 6, pp. 64-71, January/February 1991.

Duration: from: 1990 to: 1991

Funding: N/A

Status: Completed

Last Update: May 6, 1992 


\section{INDIAN POINT 2 SUB-SYSTEM DECONTAMINATIONS}

Keywords: CONTAMINATION REMOVAL; DECONTAMINATION; SUB-SYSTEM DECONTAMINATION; CAN-DEREM/AP; CITROX/AP; COBALT REMOVAL; RECONTAMINATION; INDIAN POINT 2

\section{Principal Investigator:}

John Parry

Consolidated Edison

Broadway \& Bleakley Avenues

Buchanan, NY 10511

U.S.A.

Phone: 914-526-5038

\section{Objectives:}

I. Analyze sub-system decontaminations experience at:
A) Indian Point 2 residual heat removal system
B) Indian Point 1 steam generators (SG)

II. Examine recontamination rates at Indian Point 2's Regenerative Heat Exchanger, which was first decontaminated in 1989.

\section{Comments:}

Indian Point 2 residual heat removal system:

- A five step Can-Derem/AP decontamination process was used.

- One unusual feature was that the Co-58 and Co-60 were not removed until the anion resin was used at the end of the process. The cation resin did not remove the cobalt.

- It may not be worth the cost to perform a 4 th and 5 th step, since $75 \%$ of the activity was removed after the 1st step.

- An auxiliary pump was installed that injected a $0.1 \mathrm{gpm}$ flow rate into the residual heat removal system (RHR) pump seals during the decon in order to avoid pumping decon chemicals into or through the RHR seals.

Indian Point 1 steam generators (in safe store mode since 1974):

- Used a five step Citrox/AP decon process.

- The decon chemicals could be reused on the 2nd pair of SG after the 1st pair were decontaminated due to the regenerative nature of the Citrox process.

- To simplify matters, the electrical power to operate the decon equipment was obtained via a cable from a reactor coolant pump.

- The asbestos insulating material on the SGs were found to be a problem.

Remarks/Potential for dose limitation:

Indian Point 2: 


\section{BNL ALARA Center Data Base}

J.S.A.

H-176

- The average exposure rate was $105 \mathrm{mrem} / \mathrm{hr}$ before and $7.1 \mathrm{mrem} / \mathrm{hr}$ after the decon.

- Approximately 30 rem was avoided during the 1993 outage due to the decontamination.

- The recontamination rate is being tracked between now and the next outage in 1995.

Indian Point 1:

- On the first pair of SGs 39 curies of Co-60 were removed.

- On the second pair 49 curies were removed.

- The final decontamination factor was approximately 4 .

References: Parry, John O. "Indian Point 2 Sub-System Decontaminations," Fifth Workshop on Chemical Decontamination, pp. 15.1-15.22, Electric Power Research Institute, Charlotte, North Carolina, 1993.

Duration: from: 1992 to: 1993

Funding: N/A

Status: Completed

Last Update: September 23, 1993 


\section{NATIONAL DEMONSTRATION OF A FULL RCS CHEMICAL DECONTAMINATION}

\section{Keyworcis: CONTAMINATION REMOVAL; FULL SYSTEM DECONTAMINATION; DECONTAMINATION; INDIAN POINT 2}

Principal Investigator:

John Parry

Consolidated Edison Co.

Broadway \& Bleakley Avenues

Buchanan, NY 10511

U.S.A.

Phone: $914-526-5038$

Objectives: Provide a status report on plans for a full system decontamination (FSD) of Indian Point 2 in 1995 and detail several tasks that Consolidated Edison is working on toward that goal.

Comments: In 1988 Consolidated Edison, EPRI, ESEERCO and nine other utilities began a qualification program on how to chemically decontaminate the entire Reactor Coolant System of a Westinghouse PWR. A FSD is planned for Indian Point 2 in 1995. The majority of the services for the decon will be performed by Pacific Nuclear and Westinghouse. Some of the areas that Con Ed is working on are:

1) BMI Seals - Obtain and train personnel to install new high pressure seals for use while the Bottom Mounted Instrumentation is removed during FSD

2) Clean Seal Injection for reactor coolant pump (RCP) Seal - Prevent plugging of the seal injection cartridge filter or damage to the RCP seals at high particulate levels during FSD

3) Develop a test plan to monitor every aspect of the FSD

4) Dead leg flushing - Identify areas where the piping may have to be flushed after the FSD.

5) Reactor Water Storage Tank Clean Up

6) Calculate and track decontamination factors and recontamination rates

7) Demobilization of decontamination equipment

Remarks/Potential for dose limitation: The plans to perform the first chemical decontamination of a PWR in early 1995 are on schedule. There are no major technical concerns with the implementation plan.

References: Parry, John O., "National Demonstration of a Full RCS Chemical Decontamination," Fifth Workshop on Chemical Decontamination, pp. 27.1-27.27, Electric Power Research Institute, Charlotte, North Carolina, 1993.

Duration: from: 1988 to: 1995 Funding: N/A

Status: In progress Last Update: September 30, 1993 


\section{PLANT E.I. HATCH CHEMICAL DECON 1991}

Keywords: CONTAMINATION REMOVAL; HATCH UNIT 1; SUB-SYSTEM DECONTAMINATION; DECONTAMINATION; RECIRCULATION SYSTEM

\section{Principal Investigator:}

W. Warren

Southern Nuclear Operating Company

P.O. Box 1295

Birnuingham, AL 35201

U.S.A.

Phone: 205-868-5940

\section{Project Manager:}

Same as Principal Investigator

Objectives: Outline the results of the 1991 Hatch Unit 1 Reactor Recirculation System (RRS) decontamination using AP/LOMI. Share the lessons learned from this decon operation.

\section{Comments:}

- The decon operation consisted of a two-step LOMI/LOMI application to the entire RRS, with an additional AP/LOMI application to the RRS discharge piping.

- Project duration from start of cavity drain to cavity refilled was $\mathbf{1 0}$ days.

- The process removed $28 \mathrm{~kg}$ of oxide and 72 curies of activity from the RRS. Dose rates in the inumediate vicinity of the RRS were reduced by an average factor of 8.9.

- The average dose rates on recirc piping was reduced from $>350 \mathrm{mr} / \mathrm{hr}$ to $<40$ $\mathrm{mr} / \mathrm{hr}$. Drywell dose rate went from $20.46 \mathrm{mr} / \mathrm{hr}$ previously to $12 \mathrm{mr} / \mathrm{hr}$.

- The estimated man-rem savings for two outages post decon is $>700$ man-rem.

- The recontamination rate for 1 cycle was $50 \%$

Remarks/Potential for dose limitation: Lessons learned from this decon:

1) Choose equipment that is easy to assemble

2) Maximum temperatures, flows and flow reversals will increase decon factors (DF)

3) Location of decon taps is important - injection points and flow paths directly effect the DF

4) Use pressure gauges for level indication as opposed to tygon tubing

5) Run recirculation as soon as possible after decon.

6) Tear down of decon equipment was slowed due to low spots containing water. More low point drains were needed.

7) Include procedure steps that allow repeat of steps, if needed.

8) Hang shielding as normally done.

9) Use dedicated health physics technicians.

References: Warren, W., "Plant E.I. Hatch Chemical Decon 1991," Fifth Workshop on Chemical Decontamination, pp. 9.1-9.14, Electric Power Research Institute, Charlotte, North Carolina, 1993.

Duration: from: 1991 to: 19y1

Status: Completed
Punding: N/A

Last Update: October 4, 1993 


\section{CHEMICAL DECONTAMINATION OF THE RESIDUAL HEAT REMOVAL SYSTEM}

\section{Keywords: CONTAMINATION REMOVAL; SUB-SYSTEM DECONTAMINATION; DECONTAMINATION; CITROX; RESIDUAL HEAT REMOVAL SYSTEM; BRUNSWICK UNIT 1}

\section{Principal Investigator:}

Robert Kury

Carolina Power and Light Company

P.O. Box 10429

Southport, NC 28461

U.S.A.

Phone: 919-457-3634

Objectives: Outline the procedure and summarize the results of a recent chemical decontamination performed on the CP\&L Brunswick Unit1 Residual Heat Removal (RHR) system using a one step CITROX process.

Comments: The CITROX solvent was chosen because the process is regenerative and determined to be more effective in removal of high levels of iron oxide formed on the carbon steel. The process is one of acidic dissolution and reductive dissolution with the metal ions being removed from solution by the cation resin.

The solvent was injected into each loop at the two four inch flanges located on the suction side of the RHR pumps. The heat exchangers were bypassed for approximately the first six hours of the decontamination because of concern about corrosion of the $70 / 30 \mathrm{Cu} / \mathrm{Ni}$ heat exchanger tubes. A flange was installed in the demineralized water bypass line around the RHR loop isolation valve for return of the chemicals back to the decon equipment skid. At the decon skid, the solvent flowed through the in-line filters ion exchange and the heaters, and was injected back into the RHR loop.

The expected corrosion rate for carbon steel is $<1$ micrometer $/ \mathrm{hr}$ and for austenitic stainless steel and nickel based alloys $<0.1$ micrometers $/ \mathrm{hr}$. No measured data for $70 / 30 \mathrm{Cu} / \mathrm{Ni}$ is available.

Remarks/Potential for dose limitation: The following results were achieved: (1) 3.3 Curies (primarily from Co-60) were removed, (2) $152 \mathrm{lbs}$ of iron oxide were removed, (3) Average Decontamination Factor $=26$, (4) Average Dose Reduction Factor $=9$. A total of 240 cubic feet of ion exchange resin was used during the decon process. The total cost of the RHR decon was $\$ 850,000$ and 6.6 person-rem was expended to complete the project.

References: Kury, R., Bozeman, J. and Ferguson, J., "Chemical Decontamination of the Residual Heat Removal System," Fifth Workshop on Chemical Decontamination, pp. 12.1-12.16, Electric Power Research Institute, Charlotte, North Carolina, 1993.

Duration: from: 1992 to: 1993 Funding: N/A 


\section{ONTARIO HYDRO DECONTAMINATION EXPERIENCE}

\section{Keywords: CONTAMINATION REMOVAL; FULL SYSTEM \\ DECONTAMINATION; DECONTAMINATION; CAN-DECON; CANDU}

\section{Principal Investigator:}

Project Manager:

\section{C.S. Lacy}

Ontario Hydro

700 University Avenue

Toronto, ONTARIO M5G 1 X6

CANADA

Phone: 416-506-4597

Objectives: Describe the CAN-DECON process and results obtained from past decontaminations. Discuss some key issues of design and operation that must be addressed to ensure a successful decontamination.

Comments: The essence of CAN-DECON involves the addition of the organic acids, citric acid, oxalic acid, and EDTA, to the heavy water coolant to form a $0.08 \%$ solution. These reagents dissolve and complex the corrosion product layer and radioactivity deposited on the heat transport system internal surfaces. The resultant solution is circulated through strong acid cation ion exchange resins in the purification circuit to remove the complexed metals and regenerate the reagents.

The success of decontaminations is dependent not only on the chemistry of the process itself, but also on the reliability of the decontamination purification system. A well designed system together with thorough commissioning are essential.

Training of support staff is a crucial area that cannot be overlooked. Both the needs of operating and chemical advisor staff must be addressed.

Remarks/Potential for dose limitation: Most of the Candecon decontaminations have been applied in support of reactor pressure tube maintenance. For Pickering Unit 3, the radiation dose saved is estimated at 1100 Rem for the decontamination carried out at the time of the reactor retubing outage. However, the savings increase to 4500 Rem when an earlier decontamination in support of continued operation is also considered. For Pickering Unit 4, the savings are estimated at 600 Rem, and 1850 Rem considering an earlier decontamination. For the retubing outages in these two units, maintenance personnel have been able to complete the maintenance substantially within the 2 Rem annual dose limit.

References: Lacy, C.S., "Ontario Hydro Decontamination Experience," Fifth Workshop on Chemical Decontamination, pp. 13.1-13.6, Electric Power Research Institute, Charlotte, North Carolina, 1993.

Duration: from: 1975 to: 1993

Status: In progress
Funding: N/A

Last Update: October 6, 1993 


\section{RESOURCE MANAGEMENT AS AN ALARA TOOL}

Keywords: OPERATIONAL AND MAINTENANCE TECHNIQUES; RESOURCE MANAGEMENT; ALARA; SALEM UNIT 2

\section{Principal Investigator:}

Project Manager:

Rodrick Palma

Public Service Electric and Gas

Salem - PWR/W

P.O. Box 236

Hancocks Bridge, NJ 08038

U.S.A.

Phone: 609-339-2982

Objectives: Examine the 7th Salem Generating Station Unit 2 refueling outage results.

Comments: The outage results are:
1) 100.028 person-rem
2) 129,734 RCA hours
3) $0.77 \mathrm{mR} / \mathrm{RCA}$ hour (effective dose rate)
4) 45 personnel contaminations
5) 45 respirators issued
6) 14.5 cubic meters of radioactive waste

Remarks/Potential for dose limitation: The Resource Tools created a "best ever outage" :
1) Westinghouse integrated outage package
2) Refueling outage schedule
3) Contractor Returnee's
4) "In field" work methods
5) PSP/DCP radiation protection reviews
6) Work order to ALARA review link

"In field" work methods:

1) Valve maintenance program

2) Radwaste reduction

3) Temporary shielding

4) Radiation protection technician utilization

References: Palma, R.A., "Resource Management as an ALARA Tool," 1993 Radiation Exposure Management Seminar, Westinghouse, Pittsburgh, Pennsylvania, 1993.

Duration: from: 1993 to: 1993

Funding: N/A

Status: Completed

Last Update: November 4, 1993 


\section{PWR UPPER/I.OWER INTERNALS SHIELD}

\section{Keywords: RADIATION SHIELDING; REACTOR INTERNALS; REFUELING; INDIAN POINT 2}

\author{
Principal Investigator: \\ W. Homyk \\ Con Edison of NY \\ Indian Point 2 - PWR/W \\ Broadway \& Bleakley Ave. \\ Buchanan, NY 10511 \\ U.S.A.
}

Phone: 914-526-5168

\author{
Project Manager: \\ S. Trovato \\ Con Edison of NY \\ 4 Irving Place \\ New York, NY 10016 \\ U.S.A.
}

Phone: $212-460-2090$

Objectives: The goal of this research and development program was to design, develop, test and demonstrate a shielding system which would use the existing mass of the refueling pool water to provide shielding from the protruding components of the upper internals in order to reduce the radiation exposure of refueling personnel in containment.

Comments: During refueling of a nuclear power plant, the reactor upper internals must be removed from the reactor vessel to permit transfer of the fuel. The upper internals are stored in the flooded reactor cavity. Refueling personnel typically receive radiation exposure from a portion of the highly contaminated upper internals package which extends above the normal water level of the refueling pool. At Con Edison's Indian Point 2 plant, a method of shielding was devised which would use a vacuum pump to draw refueling pool water into an inverted canister suspended over the upper internals to provide shielding from the normally exposed components. The shield system consists of a 72" high cylindrical tank with an open bottom that is suspended from outside the cavity by two I-beams. The tank is positioned to provide 18 " of immersion in the existing pool water. After installation most of the air trapped in the upper 54" of the tank is evacuated, and the vacuum draws water from the pool which fills the tank above the pool level. The "stand pipe" of water in the tank encircles the upper internals thereby providing the needed shielding.

Remarks/Potential for dose limitation: The development of the vacuum radiation shielding system resulted in significantly reduced dose rates to personnel. General area dose rates to refueling bridge personnel were reduced from $154 \mathrm{mR} / \mathrm{hr}$ to $25 \mathrm{mR} / \mathrm{hr}$. Fourteen person-rem of exposure were saved as compared to the 1991 refueling outage. At 10,000 /person-rem, the net savings for Con Edison is approximately $\$ 140,000$ per use.

References: Homyk, W.A., "PWR Upper/Lower Internals Shield," 1993 Radiation Exposure Management Seminar, Westinghouse, Pittsburgh, Pennsylvania, 1993.

Duration: from: 1992 to: 1993

Funding: N/A

Status: Completed

Last Update: November 5, 1993 


\title{
INTERNAL DOSE, RESPIRATORY PROTECTION AND REVISED 10CFR20 AT DAVIS-BESSE NUCLEAR POWER STATION
}

\author{
Keywords: OPERATIONAL AND MAINTENANCE TECHNIQUES; \\ RESPIRATORY PROTECTION; RESPIRATORS; TOTAL EFFECTIVE DOSE \\ EQUIVALENT; INTERNAL DOSE; DAVIS-BESSE
}

\section{Principal Investigator:}

Bruce Zibung

Centerior Energy Co.

Davis Besse - PWR/B\&W

5501 N. State Route 2

Oak Harbor, OH 43449

U.S.A.

Phone: 419-321-8386

Objectives: Investigate limiting the use of respirators in order to reduce the Total Effective Dose Equivalent (TEDE) for workers by allowing a small internal dose. The goal is compliance with the provisions of Title 10, Part 20 of the Code of Federal Regulations.

Comments: The DBNPS program is based on the philosophy that engineering controls are the preferred method of limiting intake of radioactive material as long as this does not result in higher total doses. The principal steps of the Respiratory Protection program at DBNPS are:

1) Determination of the area in which the job will take place.

2) Determination of the Deep Dose Equivalent (DDE) rate in the area of concern.

3) Determination of the expected fractional Derived Air Concentration (DAC) in the area of concern.

4) Determination of the efficacy of respiratory protection of any type.

5) If the use of engineering controls is justified, then apply it.

6) If the resulting air concentration after the application of engineering controls is still greater than $25 \%$ of the listed DAC, then a determination of whether a respirator would result in a lower TEDE is required.

7) Health and safety considerations may limit respirator use in areas of high temperature or on scaffolding, etc.

8) If the airborne contamination conditions are not sufficiently known in advance, respirators are used.

Remarks/Potential for dose limitation: A net savings of nearly thirty man-rem was achieved by permitting an internal dose of less than 1.5 man-rem.

This cost of the savings consisted of increased training on the concept of controlling the TEDE rather than controlling each type of dose separately and independently.

Further means of dose reduction of a similar nature can be found in the areas of excess protective clothing leading to a decrease in worker efficiency and therefore to increased stay times in radiation fields. 


\section{BNL ALARA Center Data Base}

U.S.A.

Education is the key to dose reduction. The worker, and some of the RP personnel, must be made to understand that the cell does not know which direction the particle or photon is traveling.

References: Zibung, B., Greenwood, R.A., and Mason, T., "Internal Dose, Respiratory Protection and Revised 10CFR20 at Davis-Besse Nuclear Power Station," 1993 Radiation Exposure Management Seminar, Westinghouse, Pittsburgh, Pennsylvania, 1993.

Duration: from: 1992 to: 1993

Funding: N/A

Status: Completed

Last Update: November 5, 1993 


\section{ZION UNIT 2 CYCLE 12 SHUTDOWN AND EARLY BORATION RESULTS}

Keywords: OPERATIONAL AND MAINTENANCE TECHNIQUES;

SHUTDOWN CHEMISTRY; BORATION; ZION UNIT 2

\section{Principal Investigator:}

Project Manager:

Scott Stern

Commonwealth Edison

Zion - PWR/W

101 Shiloh Blvd.

Zion, ILLINOIS 60099

U.S.A.

Phone: 708-746-2084

Objectives: The Commonwealth Edison (CECo) Zion unit 2 reactor performed early boration and hydrogen peroxide treatment for the cycle 12 refueling outage. This work summarizes the chemistry and radiological observations from Zion 2 cycle 12 and from the refueling (Z2R12) shutdown.

Comments: Some of the results are as follows:

Zion 2 cycle 12 mid-cycle outage 9-27-91:

* Outage extended beyond original end date to 11-12-91

* De-lithiated to $<0.1 \mathrm{ppm}$

* Borated to pre-determined shutdown margin (1381 ppm B max)

- Removed 127 curies Co-58 and 7.3 curies Co-60 in the 1st 6 days

- No nickel analyses requested (or performed)

* No radiological problems

Zion 2 cycle 12 mid-cycle outage 4-3-92:

- Outage extended beyond original end date to 6-19-92

- Cool to $175 \mathrm{~F}$ and maintain $175 \mathrm{~F}$ for 38 days

- 1 RCP operating and letdown demins aligned

* De-lithiated to $<0.1 \mathrm{ppm}$

- Borated to pre-determined shutdown margin (1273 ppm)

- Removed 1637 curies Co-58 and 34.8 curies Co-60

* Removed 4500-5000 grams nickel

* No radiological problems

Remarks/Potential for dose limitation:

Zion 2 cycle 12 end-of-cycle outage 11-12-92:

* De-lithiated to $<0.1 \mathrm{ppm}$

* Borated to $>2000$ ppm within 12 hours

* Removed 822 curies Co-58 and 8.6 curies Co-60. Small removal compared to previous outages.

* Removed > 4200 grams nickel. Large removal compared to previous outages. 


\section{BNL ALARA Center Data Base}

U.S.A.

H-184

* Steam generator channel head center radiation fields decreased $60 \%$ from refueling outage 11 to refueling outage 12.

End-of-cycle outage exposure totals:

- Pre-outage estimate 619 person-rem

- Actual 268.8 person-rem

* 36.6 of 268.8 person-rem was emergent work

Summary:

- Mid-cycle outage cleanup and operating chemistry control combined to contribute to radiological improvements

- May provide justification for chemistry and temperature hold during outages for ALARA purposes.

References: Stern, S., "Zion Unit 2 Cycle 12: Shutdown and Early Boration Results," 1993 Radiation Exposure Management Seminar, Westinghouse, Pittsburgh, Pennsylvania, 1993.

Duration: from: 1991 to: 1993

Funding: N/A

Status: Completed

Last Update: November 24, 1993 


\section{HEALTH PHYSICS SERVICES ON THE PLATFORM AT SALEM USING ROMMRS}

\section{Keywords: REMOTE SYSTEMS; ROMMRS; ROSA; ROBOTICS; SALEM}

\section{Principal Investigator:}

Project Manager:

Herb Cruickshank

Public Service Electric and Gas

Salem - PWR/W

P.O. Box 236

Hancocks Bridge, NJ 08038

U.S.A.

Phone: 609-339-2670

Objectives: Describe the capabilities of the Remotely Operated Managed Maintenance Robotic System (ROMMRS) and its role in performing Health Physics (HP) tasks.

Comments: ROMMRS is a joint project of Public Service Electric and Gas Company and Westinghouse Electric. The system will perform the Health Physics tasks for the primary side services planned for Steam Generators 12 and 14 at the Salem Nuclear Power Plant. The tasks to be performed at this outage with the system include: visual inspections, radiation surveys, vacuuming, wipe downs, area swiping, air sampling and equipment handling.

The robot is the ROSA I arm, slightly modified to be controlled from the ROSA III control system. The arm has 6 degrees of freedom and can be positioned anywhere within the 6 foot reach volume. It is mounted on a mobile base that travels on a triangular track with 2 degrees of freedom.

The video capabilities include two pan, tilt and zoom (PTZ) cameras and two end point cameras. The gamma radiation surveys are performed with a pair of Ebberline detectors. Beta radiation surveys are performed with a RO-2 meter.

Remarks/Potential for dose limitation: The long range vision for ROMMRS is 2 fold;

1) Reduce the radiation exposure to personnel through:

- Replacement or augmentation of HP services with robotics

- Replacement or augmentation of containment support worker services with robotics

- Track personnel exposure real time with the computer control system

- Plan tasks using a combination of the survey data base and the 3-D control model

2) Increase the productivity of the containment maintenance services through:

- Use of the 3-D simulation to provide time-motion studies to optimize the service

- Use the 3-D simulation to optimize and refresh the personnel training

- Use the data base of industry wide experience to optimize the contingency management

- Closely couple health physics services and contract services to minimize conflicts

References: Cruickshank, H., "Health Physics Services on the Platform at Salem Using ROMMRS," 1993 Radiation Exposure Management Seminar, Westinghouse, Pittsburgh, Pennsylvania, 1993.

Duration: from: 1993 to: 1994 Funding: N/A

Status: In progress

Last Update: November 29, 1993 


\section{CHEMICAL DECON OF SYSTEMS: RESULTS AND PROBLEMS}

\section{Keywords: CONTAMINATION REMOVAL; FULL SYSTEM DECONTAMINATION; SUB-SYSTEM DECONTAMINATION}

\section{Principal Investigator:}

Project Manager:

Phillip Miller

Westinghouse Electric Corporation

P.O. Box 355

Pittsburgh, PA 15230

U.S.A.

Phone: 412-374-6111

\section{Objectives:}

1) Summarize the work done to date on the National Demonstration of a full system decontamination at Indian Point 2, scheduled for 1995.

2) Summarize the fuel decontamination qualification program at the V.C. Summer site.

3) Summarize the results of the Fuel-In Full RCS Chemical Decontamination Seminar conducted on July 1993.

4) Present recent Westinghouse subsystem decontamination experience.

\section{Comments:}

1) Phase 2 - Decon Process Qualification and Detailed Engineering Evaluation - of the National FSD Demonstration Program was completed in Jan. 1991. Waste Certification Program completed by Chem Nuclear Systems in 1993. Program is on schedule for FSD in 1995.

2) Fuel Decon Qualification Program was completed at V.C. Summer in 1993. It was found that the post-decon fuel cladding corrosion behavior was unaffected by decontamination processes.

3) All attending utilities at the Fuel-In Full RCS Chemical Decon Seminar expressed interest in establishing a comprehensive program leading to qualification of fuel-in FSD. Westinghouse will elicit additional support and report back.

4) Westinghouse has conducted 18 sub-system decon applications at 11 different plants from $8 / 91$ to $3 / 93$. Fourteen of the applications were performed at BWRs, the rest at PWRs. The processes used include LOMI, CAN-DEREM, CANDECON and CITROX.

Remarks/Potential for dose limitation: A successful FSD will have significant impact on efforts to reduce worker radiation field exposure. Westinghouse, in conjunction with several utilities and other organizations, are on schedule for a 1995 FSD demonstration.

References: Miller, P. and Schwartz, C., "Chemical Decon of Systems: Results and Problems," 1993 Radiation Exposure Management Seminar, Westinghouse, Pittsburgh, Pennsylvania, 1993.

Duration: from: 1990 to: 1993 Funding: N/A

Status: In progress Last Update: November 29, 1993 


\title{
AN AUTOMATED PROGRAM IMPLEMENTING NEW 10CFR20 REQUIREMENTS AT SOUTHERN NUCLEAR PLANTS
}

Keywords: OPERATIONAL AND MAINTENANCE TECHNIQUES; 10CFR20; DOSIMETRY SOFTWARE; SOFTWARE

\author{
Principal Investigator: Project Manager: \\ Prince Patton \\ Southern Nuclear Company \\ Farley - PWR/W \\ P.O. Drawer 470 \\ Ashford, AL 36312 \\ U.S.A.
}

Phone: 205-899-5156

Objectives: Describe the development and implementation of an integrated software system developed by Canberra Nuclear for the three Southern Nuclear plants Farley, Hatch, and Vogtle in compliance with the new 10CFR20 regulations.

Comments: Approximately two and a half years ago Southern Nuclear Company (SNC) initiated a task force to investigate a common methodology for its three nuclear plants to implement the new 10CFR20 regulations. A contract was awarded to Canberra Nuclear to develop an integrated software system for this purpose.

There are two software subsystems and several major modules associated with them. Each module is either in use or undergoing final site testing at the plants. They are:

1) Health Physics Data System

- HIS-20: Health Physics Information System

- ABACOS Plus Whole Body Counting System
2) Counting and Chemistry Data System

- CAS: Countroom Analysis System

- EMS: Effluent Management System

- CDM: Chemistry Data Mgt System

Remarks/Potential for dose limitation: The lessons learned from this project are:

1) Write a detailed specification on what you want and how you expect it to perform, with a payment schedule linked to satisfactory completion of key tasks.

2) Select knowledgeable personnel to work on the project and empower them with the authority to make decisions. Keep these people through the completion of the project.

3) Work closely with the vendor on every phase of the project.

4) Insist on a detailed vendor test plan and testing before you begin your testing.

5) Perform detailed testing at the vendor's factory and again at the site before acceptance.

6) Train users early enough to get them familiar with the new system.

References: Patton, P., "An Automated Program for Implementing New 10 CFR20

Requirements at Southern Nuclear Plants," 1993 Radiation Exposure Management Seminar, Westinghouse, Pittsburgh, Pennsylvania, 1993.

Duration: from: 1991 to: 1993

Funding: N/A

Status: In progress

Last Update: November 30, 1993 


\section{STEAM GENERATOR REPLACEMENT PROJECT AT NORTH ANNA POWER STATION}

Keywords: OPERATIONAL AND MAINTENANCE TECHNIQUES; STEAM GENERATOR REPLACEMENT; NORTH ANNA

\section{Principal Investigator:}

Jim Schleser

Virginia Power

North Anna Power Station

P.O. Box 402

Mineral, VA 23117

U.S.A.

Phone: 703-894-2419

\author{
Project Manager: \\ Martin W. Gettler \\ Virginia Power \\ Innsbrook Technical Center \\ 5000 Dominion Blvd \\ Glen Allen, VA 23060 \\ U.S.A.
}

Phone: 804-273-2124

Objectives: Summarize the steam generator replacement (SGR) project at North Anna Power Station.

Comments: Some of the problems that led to the S/G replacement were:

- intergranular and primary water stress corrosion cracking

- circumferential cracking

- tubesheet dose rates of 25 to $35 \mathrm{Rem} / \mathrm{Hr}$

- extensive $S / G$ inspection and maintenance scope expending from 80 to 200 man-rem per outage

- outage duration of 55 to 77 days due to $S / G$ activity

Some of the practices contributing to the success of the project:

- early and effective planning

- successful mock up training program

- aggressive radiological protection measures

- extremely low respirator usage through effective HEPA

- ventilation and other engineering controls

- extensive use of remote tooling and robotics

- good engineering

- little rework or out of scope work

Remarks/Potential for dose limitation: The dosage data for the project are:

Projections: (1) 540 Rem for all work, (2) 482 Rem for SGR work only, (3) goal of 110 personnel contamination events for all work, (4) goal of 11,000 cubic $\mathrm{ft}$ of radwaste or less

Actual results: (1) 313 Rem for all work, (2) 240 Rem for SGR work only, (3) 59 personnel contamination events for all work, (4) 3,600 cubic ft of radwaste generated

References: Banks, T., "Steam Generator Replacement Project at North Anna Power Station," 1993 Radiation Exposure Management Seminar, Westinghouse, Pittsburgh, Pennsylvania, 1993.

Duration: from: $1 / 93$ to: $4 / 93 \quad$ Funding: N/A

Status: Completed

Last Update: December 31, 1993 


\section{ALARA PROGRAMME MANAGEMENT AND ORGANIZATION IN EDF NUCLEAR POWER STATIONS}

Keywords: OPERATIONAL AND MAINTENANCE TECHNIQUES; ALARA; EDF

Principal Investigator:

Maurice Perin

Electricite de France/DSRE

6 Rue Ampere BP 114

93203 Saint Denis Cedex 01

FRANCE

Phone: +331492281 75

\author{
Project Manager:
}

Objectives: Implement the ALARA principle during the operational phases of EDF's installations, and especially during maintenance.

Comments: EDF has taken steps to implement ALARA at its plants. Issues considered are:

1) Implementation of the ALARA Process

- integration of radioprotection into the power station management process

- consider dosimetric indicators the same as other indicators concerning power station operation (maintenance cost, etc.)

- the methodology applied is based on two levels: national and local; the fundamental principle is that of local responsibility and initiative

2) Longevity of the ALARA structures

- The ALARA structures were implemented in late 1991, and it is too early to draw any conclusions concerning their longevity.

3) I. ontives to apply the ALARA principle

- EDF intends to direct motivation toward how to reduce exposure, not how to receive an aware; therefore, no special incentives are considered for EDF staff.

- Contractual incentives are offered to outside contractors.

Remarks/Potential for dose limitation: The long-term production of nuclear powered electricity requires that two conditions be met: (1) acceptance by public opinion and (2) ability to provide $\mathrm{kWh}$ at the lowest cost. Radioprotection plays a part in the fulfillment of both.

Today, EDF is basing its action on the ALARA concept, which is difficult to implement as it is based on the involvement of many participants. However, it is also very motivating, as national and international experience is showing excellent results.

Improved quality = Lower doses, and therefore higher economic efficiency.

References: Perin, M., "ALARA Programme Management and Organization in EDF Nuclear Power Stations," 1993 Radiation Exposure Management Seminar, Westinghouse, Pittsburgh, Pennsylvania, 1993.

Duration: from: 1990 to: 1994

Funding: N/A

Status: In progress

Last Update: December 1, 1993 


\section{ENHANCED RADIATION WORKER TRAINING AT JAMES A.}

\section{FITZPATRICK NUCLEAR PLANT}

\section{Keywords: OPERATIONAL AND MAINTENANCE TECHNIQUES; \\ RADIATION PROTECTION; WORKER TRAINING; ALARA; FITZPATRICK}

\author{
Principal Investigator: \\ John McCarty \\ New York Power Authority \\ FitzPatrick - BWR/GE \\ P.O. Box 41 \\ Lycoming, NY 13093 \\ U.S.A.
}

Phone: 315-349-6642

\author{
Project Manager: \\ John Hamblin \\ New York Power Authority \\ FitzPatrick - BWR/GE \\ P.O. Box 41 \\ Lycoming, NY 13093 \\ U.S.A.
}

Phone: 315-349-6642

Objectives: Investigate the radiation protection problems at the New York Power Authority (NYPA) FitzPatrick Plant and steps taken to improve radiological performance.

Comments: The FitzPatrick Plant experienced a significant decline in radiological performance from early 1987 through early 1992 . There were several serious radiological incidents involving unplanned exprosure and extremity overexposure to workers. The radiation protection program was criticized by the NRC for (a) weak supervisory oversight, (b) poor adherence to procedures by the plant staff and (c) weak training. Some of the recurring radiation protection $(\mathrm{RP})$ problems were:

1) Inadequate communication with Radiation Protection

2) Improper usage of HEPA ventilation

3) High Radiation Area key control

4) High Radiation Area boundary control

5) Unplanned spread of contamination

6) Lack of dosimetry in the plant Restricted Area

To address this situation, NYPA management instituted a Radiological Improvement Plan. The development of the Enhanced Radiation Worker (ERW) Training Program was one of many items contained in the plan.

Remarks/Potential for dose limitation: In Dec. 1991 a pilot session of the ERW program was conducted.

The instruction techniques include:

- lecture

- practical exercises in the simulated hot laboratory

- computer animation

- video taping of exercises

- facilitation of class critiques

The course contents include:

- basic radiation/contamination concepts

- radiation protection procedures and policies

- industry events 
- work planning

- ALARA

- contamination control

During 1992, 350 plant workers were trained and there were significant improvements in radiological awareness and performance. The SALP (systematic assessment of licensee performance) rating was increased from 3 (adequate) to 2 (good).

References McCarty, J. and Hamblin, J., "Enhanced Radiation Worker Training at James A. FitzPatrick Nuclear Plant," 1993 Radiation Exposure Management Seminar, Westinghouse, Pittsburgh, Pennsylvania, 1993.

Duration: from: 1991 to: 1994

Funding: N/A

Status: In progress

Last Update: December 1, 1993 


\section{S/G REPLACEMENT AT BEZNAU 1: EXPERIENCE AND RESULTS IN RADIOLOGICAL PROTECTION}

\section{Keywords: COMPONENT RELIABILITY; STEAM GENERATOR REPLACEMENT; RADIOLOGICAL PROTECTION; BEZNAU}

Principal Investigator:

Urs Weidmann

NOK

Bernau - PWR/W

$\mathrm{CH}-5312$

Dottingen

SWITZERLAND

Phone: + 4156997584
Project Manager:

Objectives: Describe the preparation, implementation, and results of the steam generator replacement at the Swiss Beznau 1364 MW Westinghouse reactor in the context of radiological protection.

Comments: The two steam generators and sections of the reactor coolant lines were replaced at Beznau 1 in Spring 1993. This replacement qualifies as a new record in two areas: the time required to complete the principal operation took only 44 days and the radiation exposure was not higher than $1100 \mathrm{mSv}$ (110 man-rem).

This low dose was achieved by using proven techniques and methodology in radiological protection. Some of the most important techniques were:

- Detailed planning of the radiation protection measures and procedures

- Intensive personal training (mock-up training)

- Shielding (a total of $80 \mathrm{t}$ of lead had been installed)

- Installation of special "radiation islands" in the containment by means of shielding to allow a low dose area for workers to discuss problems

- Mechanical decontamination of the piping ends

Remarks/Potential for dose limitation: The effective total radiation exposure was below the projected dose. Some reasons for this were: 1) fewer man-hr than expected for some tasks, 2) unexpected good results about the continuous modifications at the shielding during the replacement operations, 3) the installed "radiation islands" were often used, especially in the first phase of the replacement operation

References: Weidmann, U., "S/G Replacement at Beznau 1: Experience and Results in Radiological Protection," 1993 Radiation Exposure Management Seminar, Westinghouse, Pittsburgh, Pennsylvania, 1993.

Duration: from: 1985 to: 1993 Funding: N/A

Status: Completed 


\section{PARTNERS IN PERFORMANCE: AN ALARA PERSPECTIVE}

Keywords: OPERATIONAL AND MAINTENANCE TECHNIQUES; ALARA

\section{Principal Investigator:}

Gary White

Westinghouse Electric

P.O. Box 158 (MS 8)

Madison, PA 15663-0158

U.S.A.

Phone: 412-722-5438

\author{
Project Manager: \\ Craig Helmen \\ Pacific Gas \& Electric \\ Diablo Canyon - PWR/W \\ P.O. Box 56 (104-5-14A) \\ Avila Beach, CA 93424 \\ U.S.A.
}

Phone: 805-545-4681

Objectives: Present the benefits to a partnership between site and vendor ALARA.

Comments: "Partners in Performance" denotes: (1) An agreement to work together for a common goal, (2) An understanding that if one side benefits, the other side benefits, and (3) A decision that both the NSSS vendor and the utility are in this business together. RP and NSSS vendor cooperation leads to increased communication, decreased misperceptions, less stress and less exposure.

An effective means in improving communications between work groups is through the use of a liaison. This had always been done with the production group. Through lessons learned at a utility prior to working with the Diablo Canyon Power Plant (DCPP), the vendor decided to use an ALARA Engineer as the liaison. This proved to be very effective at this utility. It was decided that an RP liaison, an ALARA Engineer, would be utilized at DCPP. This formed the basis for ALARA Partners in Performance. DCPP's ALARA program and Vendor Radiation Exposure Management benefited greatly from this partnership.

Remarks/Potential for dose limitation: Benefits of an ALARA Partnership:

- It provides a "common thread" between utilities performing similar work scopes.

- It provides a single point contact for addressing radiological concerns.

- It provides a pathway for lessons learned to be followed for implementation by both parties.

- It enables the focus of effort to be on "real", not "perceived" problems.

- It insures support activities (ie, scaffolding) be implemented correctly the first time.

- It streamlines radiological control implementation, minimizing impediments to production duration.

- It benefits the utility by enabling planned work scopes to be completed using less schedule time.

- It benefits the vendor by reducing personnel exposures, thereby assuring extensive use of experienced personnel on subsequent jobs and improved job performance.

- It assures that ALARA is more than just hanging lead.

References: Helmen, C. and White, G., "Partners in Performance: An ALARA Perspective," 1993 Radiation Exposure Management Seminar, Westinghouse, Pittsburgh, Pennsylvania, 1993.

Duration: from: 1993 to: 1994 Funding: N/A

Status: In progress Last Update: December 3, 1993 


\section{STEAM GENERATOR SNUBBER ELIMINATION}

Keywords: COMPONENT RELIABILITY; SNUBBER ELIMINATION; STEAM GENERATOR; WOLF CREEK; CALLAWAY

\section{Principal Investigator:}

Chris Stirzel

Westinghouse Electric Corporation

P.O. Box 355

Pittsburgh, PA 15230

U.S.A.

Phone: 412-374-6678

\author{
Project Manager: \\ Steven A. Palm \\ Westinghouse Electric Corporation \\ P.O. Box 355 \\ Pittsburgh, PA 15230 \\ U.S.A.
}

Phone: 412-374-6452

Objectives: Implement the Westinghouse Steam Generator Snubber Elimination Program at the Wolf Creek and Callaway plants.

Comments: The continuing need to monitor, inspect, and periodically test the performance of the SG snubbers are costly in terms of exposure and man-hours. However, recent advancements in computer technology have made it economically feasible to perform the engineering analyses necessary to eliminate $100 \%$ of the SG snubbers in nuclear power plants.

The Westinghouse Steam Generator Snubber Elimination Program implements the load reduction techniques of Leak-Before-Break, Elimination of Arbitrary Intermediate Breaks, and ASME Code Case N-411 damping. The new approach now also includes non-linear time history seismic and pipe break analyses to more accurately predict the loadings on the reactor coolant system components.

The Wolf Creek Nuclear Operating Company \& the Union Electric Company are embarking on a program to eliminate all 32 Steam Generator Large Bore Hydraulic Snubbers. The resulting savings in reduced man-rem exposure, maintenance, and inspection is significant. The payback period is estimated to be just two years.

Remarks/Potential for dose limitation: The benefits of SG snubber elimination identified by Wolf Creek and Union Electric are as follows. Similar benefits would be experienced at other nuclear stations.

- Achieves ALARA: exposure reduced by approximately 3 man-rem per outage.

- Eliminates visual inspection and functional testing: saves $\$ 35,000$ per outage.

- Reduces the risk of outage extension and unplanned outages

- Reduces maintenance and refurbishment costs: saves $\$ 15,000$ per outage

- Reduces outage activities

- Improves plant reliability by reducing congestion and snubber failures

- Increases plant availability

References: Stirzel, C., "Steam Generator Snubber Elimination," 1993 Radiation Exposure Management Seminar, Westinghouse, Pittsburgh, Pennsylvania, 1993.

Duration: from: 1992 to: 1994

Funding: N/A

Status: In progress

Last Update: December 6, 1993 


\section{FUTURE POWER STATIONS IN THE UNITED KINGDOM: DESIGNING FOR LOW DOSES}

Keywords: CONTAMINATION PREVENTION; DOSE REDUCTION; FUEL CYCLE; ZIRCALOY; COOLANT CHEMISTRY; STELLITE; SIZEWELL B

Principal Investigator: Project Manager:

Alan Willcock

Nuclear Electric

Sizewell B - PWR/PPP

Booths Hall, Knutsford

Cheshire, WA16 8QG

U.K.

Phone: +44565682439

Objectives: Utilize the design experience from the Sizewell 'B' nuclear power station nearing completion to develop potential steps that can be taken to improve operator doses on future PWR plants in the U.K.

Comments: Nuclear Electric is currently building its first commercial PWR station, Sizewell 'B', in Suffolk, England. It is based upon the Westinghouse Standard Nuclear Unit Power Plant. (SNUPPS). With Sizewell 'B' nearing completion, Nuclear Electric is already looking to the design of any further stations to be built in the UK. These future plants are likely to be Sizewell 'B' replicas but attention would still be given to reducing operator doses further.

An assessment of the operator doses for Sizewell 'B' concluded that for the planned 12 month fuel cycle the annual dose would be 1.97 man-Sv (197 man-Rem). The maximum individual dose was calculated to be $8.5 \mathrm{mSv}(0.85 \mathrm{Rem})$. This was a conservative estimate because it did not reflect all the source reduction steps taken for the plant.

Remarks/Potential for dose limitation: The Sizewell 'B' design was effectively frozen in the mid to late 1980's. However, since then significant improvements has been made in the operation of PWRs and radioactive source reduction. The following are considered to be the most important features for consideration for future plants:

- Adoption of an 18 month fuel cycle

(97 man-Rem)

- Adoption of Zircaloy fuel grids

(76 man-Rem)

- Adoption of high $\mathrm{pH}$ chemistry

(57 man-Rem)

- Stellite removal

(35 man-Rem)

The items listed can provide both significant financial advantages and greater operational flexibility in achieving the low dose targets.

References: Willcock, A., "Future Power Stations in the United Kingdom: Designing for Low Doses," 1993 Radiation Exposure Management Seminar, Westinghouse, Pittsburgh, Pennsylvania, 1993.

Duration: from: 1992 to: 1994

Funding: N/A

Status: In progress

Last Update: December 8, 1993 


\title{
A TEAM APPROACH FOR THE MANAGEMENT OF RADIOACTIVE LIQUID EFFLUENTS
}

Keywords: OPERATIONAL AND MAINTENANCE TECHNIQUES; CONTAMINATION REMOVAL; LIQUID EFFLUENTS; RADWASTE DISPOSAL; DAVIS-BESSE

\author{
Principal Investigator: \\ John Priest \\ Centerior Energy Co. \\ Davis Besse - PWR/B\&W \\ 5501 N. State Route 2 \\ Oak Harbor, OH 43449 \\ U.S.A.
}

Project Manager:

Phone: 419-321-8560

Objectives: Streamline the management of liquid effluents at the Davis Besse Nuclear Power Station.

Comments: The management of liquid effluents at most PWRs is complex due to responsibility being shared by various departments. A team approach is necessary to provide effective control of all radioactive liquid effluents to reduce dose to the public and maintain processing costs as low as possible.

At Davis Besse, the administrative control over liquid radwaste processing has been particularly complex for various reasons. They have proposed to form a radiological effluent management team that will develop policy that coordinates plant activities and operations that generate, process and release radioactive liquid effluents. The proposed objectives of the team are: 1) Reduce the source term for radioactive effluents, 2) Minimize unnecessary liquid from entering the radioactive liquid waste processing system, 3) Determine the type of processing media to be utilized, 4) Perform routine review of the processing system, 5) Plan for infrequent events such as resin replacement or system flushing, and 6) Provide a communication route.

Remarks/Potential for dose limitation: Reducing liquid effluent activity requires a management culture which commits the cooperation and coordination of the entire station. Long term vision should be reflected in a written radwaste policy. Communication can affect "buy in" from station personnel. One has to address the source term. Small leaks need to be located and repaired. Modifications and work orders need to be reviewed to eliminate "clean" water from the radwaste stream. Vendors need to be pushed to continue to develop improved technology to achieve better activity removal factors.

References: Priest, J., "A Team Approach for the Management of Radioactive Liquid Effluents," 1993 Radiation Exposure Management Seminar, Westinghouse, Pittsburgh, Pennsylvania, 1993.

Duration: from: 1992 to: 1994

Funding: N/A

Status: In progress

Last Update: December 13, 1993 


\section{BNL ALARA Center Data Base}

\section{ALARA AND WORK MANAGEMENT}

Keywords: OPERATIONAL AND MAINTENANCE TECHNIQUES; ALARA; WORK MANAGEMENT; DOSE REDUCTION; EDF

Principal Investigator:

Caroline Schieber

CEPN

BP 4892263 Fontenay-Aux-Roses

Cedex

FRANCE

Phone: + 33146547467

\section{Project Manager:}

Objectives: Examine the effects of work management on occupational exposures.

Comments: Within the framework of its ALARA program for the French nuclear power plants, EDF (Electricité de France) has initiated a pluri-annual research project conducted by CEPN in order to delineate the various factors related to work management which can influence occupational exposures and to evaluate the effectiveness of possible protection actions influencing these factors. Three different categories of factors have been defined: the factors linked to working conditions (ergonomic of work areas, adaptation of tools...), those characterizing the operators (qualification, experience level, motivation...) and the factors directly depending on the operations' organization (tasks planning, general preparation of works...). The results have been complemented by a survey carried out in five French nuclear power plants and focused on three types of operations: primary valves maintenance, decontamination of reactor cavity, and some specialized maintenance operations.

Remarks/Potential for dose limitation: The results of the first 2 years of study tend to confirm that a great potential for reducing exposures can be obtained through work management actions without spending vast sums of money. However, ALARA implementation needs the support of management, especially in the following stages:

1) Preparation of maintenance operations

- integration of areas "design" into and procedures

- planning by working area

- prediction of exposure taking into account real dose rates

2) Follow up

- implementation of systematic data collection network

- quantification of doses due to mishaps

3) Feed back experience

- use of databases to rapidly communicate lessons learned

- comparison between dosimetric performances must be done by reference to a same level of ambient dose rate

References: Schieber, C., "ALARA and Work Management," 1993 Radiation Exposure Management Seminar, Westinghouse, Pittsburgh, Pennsylvania, 1993.

Duration: from: 1991 to: 1994

Funding: N/A

Status: In progress

Last Update: December 14, 1993 


\title{
RADIOLOGICAL ASSESSMENT OF DECOMMISSIONING AT FORT ST. VRAIN
}

\author{
Keywords: CONTAMINATION REMOVAL; DECOMMISSION; \\ DECONTAMINATION; ALARA; FORT ST. VRAIN
}

\section{Principal Investigator:}

Project Manager:

Ted Borst

Public Service Co. of Colorado

Fort St. Vrain - HTGR/GA

16805 WCR 19-1/2

Platteville, CO 80651

U.S.A.

Phone: $303-620-1000$

Objectives: Present the current status of the decommissioning effort at the Public Service Co. of Colorado (PSC) Fort St. Vrain (FSV) reactor.

Comments: The decontamination option was chosen over safe storage for decommissioning. The goal is to reduce the amount of residual radioactive material remaining on the Fort St. Vrain site to a level acceptable for the termination of the FSV operating license.

Fort St. Vrain Background Information:

- first and only of its kind in the US: 330 MWE HTGR reactor

- poor operational performance $(<15 \%)$

- outstanding radiological performance (avg 3 person-rem/year)

- high cost, poor performance basis for planned 6/1990 shutdown

- equipment failures prompted premature shutdown in 8/1989

Scope of the FSV decon:

- decontamination and dismantlement of the prestressed concrete reactor vessel (PCRV) containing $90-95 \%$ of radioactivity

- decontamination and dismantlement of contaminated balance of plant systems with the remaining $5-10 \%$ of radioactivity

- site cleanup and final site release survey

- release of site for unrestricted use, likely as repowered electric generating facility

Remarks/Potential for dose limitation: Radiological Assessment:

- All project person-rem recorded exposures have been under the goals and estimates

- No positive internal body burdens have been recorded

- Workers have submitted over 100 exposure saving ideas with over 80 implemented

- Over 5,000 formal radiological classroom training hours have been conducted

- The project has conducted numerous job specific rad worker training classes to ensure workers understand the job task to be performed.

- No project NRC violations have been recorded. 


\section{BNL ALARA Center Data Base}

U.S.A.

Project ALARA Program includes:

1) aggressive shielding program

2) contamination control

6) integrated work package reviews

3) mock up training program

7) communication usage

4) radiological engineering controls

8) special instrumentation

5) ALARA awareness programs

9) video camera usage

References: Borst, T., "Radiological Assessment of Decommissioning at Fort St. Vrain," 1993 Radiation Exposure Management Seminar, Westinghouse, Pittsburgh, Pennsylvania, 1993.

Duration: from: 1989 to: 1995

Funding: N/A

Status: In progress

Last Update: December 14, 1993 


\section{BNL ALARA Center Data Base}

U.S.A.

H-198

\section{PERSONNEL RADIATION EXPOSURE REDUCTION DURING REMOTE STUD HANDLING AT INDIAN POINT 2}

\section{Keywords: REMOTE SYSTEMS; REMOTE STUD HANDLING; DOSE REDUCTION; INDIAN POINT 2; REACTOR VESSEL STUDS}

\author{
Principal Investigator: \\ Dave Bishop \\ Con Edison \\ Indian Point 2 - PWR/W \\ Broadway \& Bleakley Ave. \\ Buchanan, NY 10511-1099 \\ U.S.A.
}

Phone: 914-734-5757

\author{
Project Manager: \\ Mike Reinhardt \\ Westinghouse Electric Corp \\ P.O. Box 158 \\ Madison, PA $15663-0158$ \\ U.S.A.
}

Phone: 412-722-5023

Objectives: Describe the usage of the remote study handling system during the February 1993 refueling outage at Indian Point 2.

Comments: The automated stud handling system employs a transport segment system to remove and install reactor vessel studs, nuts, and washers. The transport segment is a precision fabrication which sits on the reactor vessel covering $1 / 4$ of the bolt circle. A track assembly on the top of the transport segment guides 2 automated stud turning robots. These two robots are connected to a central control panel which is located on the refueling deck.

Using a special lifting beam, the first transport segment along with the two automated stud turning robots is positioned on the reactor vessel head. Two operators are located in the cavity to align the transportation segment on the head. Once the transportation segment is properly positioned the stud removal process is initiated from the remote control panel on the refueling deck. The operators in the cavity detach the lifting beam assembly from the transportation segment and then move to a lower dose area during the stud removal sequence.

Remarks/Potential for dose limitation: Using the remotely operated stud system during refuel $11 / 12$, which started in $2 / 1993$, studs were removed in 6.5 hours with a total exposure of $498 \mathrm{mRem}$. Stud insertion was completed in 6.5 hours with $1045 \mathrm{mRem}$ exposure.

Total outage exposure results using the remote stud handling system:

$\begin{array}{lllll}\text { OUTAGE } & \text { MAN HOURS } & \text { DOSE RATE FIELD } & \text { CRITICAL PATH } & \text { EXPOSURE } \\ 1991 & 160.5 & 250 \mathrm{mRem} / \mathrm{Hr} & 26.75 \mathrm{Hr} & 6.258 \mathrm{Rem} \\ 1993 & 65.00 & 250 \mathrm{mRem} / \mathrm{Hr} & 13.00 \mathrm{Hr} & 1.543 \mathrm{Rem} \\ \text { \% savings } & & & & \\ 1993 \text { vs 1991 } & 59.6 \% & \text { N/A } & 51.41 \% & 75.35\end{array}$

References: Bishop, D., "Personnel Radiation Exposure Reduction During Remote Stud Handling at Indian Point 2," 1993 Radiation Exposure Management Seminar, Westinghouse, Pittsburgh, Pennsylvania, 1993.

Duration: from: 1993 to: 1993 Funding: N/A

Status: Completed Last Update: December 15, 1993 


\section{REPLACEMENT OF RWCU PIPING WITH STATE-OF-THE-ART MATERIALS}

\section{Keywords: CONTAMINATION REMOVAL; REACTOR WATER CLEANUP SYSTEM; SUB-SYSTEM DECONTAMINATION; PERRY}

\section{Principal Investigator:}

Project Manager:

Gerry Kindred

Cleveland Electric Illuminating Company

Perry Nuclear Power Plant

10 Center Road

North Perry, OH 44081

U.S.A.

Phone: 216-259-3737

Objectives: Replace the reactor water cleanup system (RWCU) piping at the Perry Nuclear Power Plant and record the dose savings resulted from it.

Comments: Perry Nuclear Power Plant is a $1250 \mathrm{~mW}$ BWR. During the Second Refueling Outage in 1990, about 300 person-rem was expended for work in areas of the drywell adjacent to the RWCU cross-tie line. This 140 feet long, 4 inch diameter carbon steel line connected the two loops of the reactor recirculation system and the RPV bottom head drain line.

To reduce the radiation field in this area, a decision was made to:

1) chemically decontaminate the piping using LOMI

2) cut the pipe into sections that would easily fit into the B25 shipping container

3) replace the pipe along the same routing

4) replace the carbon steel with stainless steel

5) process the replacement pipe to mitigate recontamination, ie, electropolishing and passivation

347 NG stainless steel was selected as the replacement piping material because of:

1) IGSCC resistant per NUREG 0313

2) low cobalt

3) no increase in ISI requirements

4) good weldability

5) good availability

6) corrosion resistant

Remarks/Potential for dose limitation:

ALARA actions to minimize personnel dose:

mock-up training

- chemical decon

" catch containments

- HEPA ventilation

- wireless communications

- closed circuit TVs
- The chemical decontamination skid was located in the fuel handling building away from traffic areas.

* shielded demineralizers and filters

* remotely operated tools

" low dose waiting areas 


\section{BNL ALARA Center Data Base}

U.S.A.

General area dose-rates were reduced by a factor of 5.2 (80.8\%). A better general area DF would have been realized if the reactor recirculation system pumps and piping could have been included in the LOMI flowpath.

During the second refueling outage average shielded general area dose-rates in the drywell on the 583' and 599' elevation were 0.093 and $0.078 \mathrm{mR} / \mathrm{hr}$. During the 1993 mid-cycle outage the average unshielded general area dose-rates were 0.064 and $0.064 \mathrm{mR} / \mathrm{hr}$.

References: Kindred, G. W., "Replacement of RWCU Piping With State-of-the-Art Materials," Radiation Field Control Seminar, Electric Power Research Institute, Seattle, Washington, 1993.

Duration: from: 1990 to: 1993

Runding: $N / A$

Status: Completed

Last Update: December 21, 1993 


\section{BNL ALARA Center Data Base}

\section{EVALUATION OF ZIRCALOY FUEL CLAD OXIDATION AT MILLSTONE 3 PWR}

Keywords: COMPONENT RELIABILITY; ZIRCALOY; MILLSTONE; FUEL CLADDING

Principal Investigator:

M.V. Folley

Nuclear Electric

Berkeley Technology Centre

Berkeley, GLOUCESTERSHIRE GL13 9PB

U.K.

Phone: 44-453-812450
Project Manager:

Suresh K. Yagnik

Nuclear Power Division

Electric Power Research Institute

3412 Hillview Avenue

Palo Alto, CA 94304

U.S.A.

Phone: 415-855-2411

Objectives: Analyze plant data on Zircaloy-4 clad oxide thickness taken from Millstone 3 in comparison with data from North Anna 1.

\section{Comments:}

COOLANT LITHIUM EFFECTS ON ZIRCALOY-4 CLAD OXIDE THICKNESS:

- Summary of laboratory tests

- No voidage, no B, 3.5 ppm Li

$\rightarrow 2 \%$ to $5 \%$ increase compared with $2.2 \mathrm{ppm} \mathrm{Li}$

- No voidage, $>50 \mathrm{ppm} B, 3.5 \mathrm{ppm} \mathrm{Li} \rightarrow$ negligible increase

- High voidage, any $\mathrm{B}$, any $\mathrm{Li} \quad \rightarrow$ large increase

- Plants do not operate with high voidage: effect may be slight

- Need to check actual plant data, especially for thick oxides

- Hence EPRI/Westinghouse program at Millstone 3 and comparison plant, North Anna 1.

EPRI contracted Nuclear Electric to analyse results.

SUMMARY OF OXIDE THICKNESS RESULTS:

- Millstone (Elev) 13\% or 14\%* higher than N Anna (Co-ord)

- Millstone One Cycle exposures (few rods only): D, E Assemblies (Elev) 29\% or $42 \%$ * lower than $A$ assemblies (Co-ord)

- Millstone Two Cycle exposures: D Assemblies (Elev) $33 \%$ or $36 \% *$ lower than B, C assemblies

(Co-ord and Elev)

- All above results significant at $>99 \%$ confidence level

- Hence inconsistent results on $\mathrm{Li}$ effect

- Inconsistency probably due to batch-to-batch differences in standard $\mathrm{Zr}-4$ clad

- One value from slope of fit to measured vs predicted, the other from mean measured/predicted ratios

Remarks/Potential for dose limitation:

- Inconsistent apparent effect of Elevated Li Chemistry:

- Millstone/N Anna, higher oxidation

- Millstone/Millstone, lower oxidation 


\section{BNL ALARA Center Data Base}

U.S.A.

H-200

- Likely reason for inconsistency is batch-to-batch variation in cladding:

- Composition

- Annealing

- Cannot conclude from this study that Elevated Li enhanced Millstone oxide thicknesses

- Future work: measure oxide thicknesses after Millstone cycle 4 exposed to Co-ordinated $\mathrm{pH}(308) 6.9$ chemistry

References:

Swan, T. and Polley, M.V., "Zircaloy Fuel Clad Oxidation at Millstone 3 PWR," Radiation Field Control Seminar, Electric Power Research Institute, Seattle, Washington, 1993.

Polley, M.V. and Evans, H.E., "A Comparison of Zircaloy Oxide Thicknesses on Millstone 3 and North Anna 1 PWR Fuel Cladding," EPRI TR-102826 Report, Electric Power Research Institute, Palo Alto, CA, 1993.

Duration: from: 1992 to: 1993

Funding: N/A

Status: Completed

Last Update: January 4, 1994 


\section{AN UPDATE ON CHEMISTRY RELATED DOSE REDUCTION EFFORTS AT MILLSTONE NUCLEAR GENERATING STATIONS}

\section{Keywords: OPERATIONAL AND MAINTENANCE TECHNIQUES; CONTAMINATION PREVENTION; WATER CHEMISTRY; ZINC INJECTION; COBALT REDUCTION; MILLSTONE}

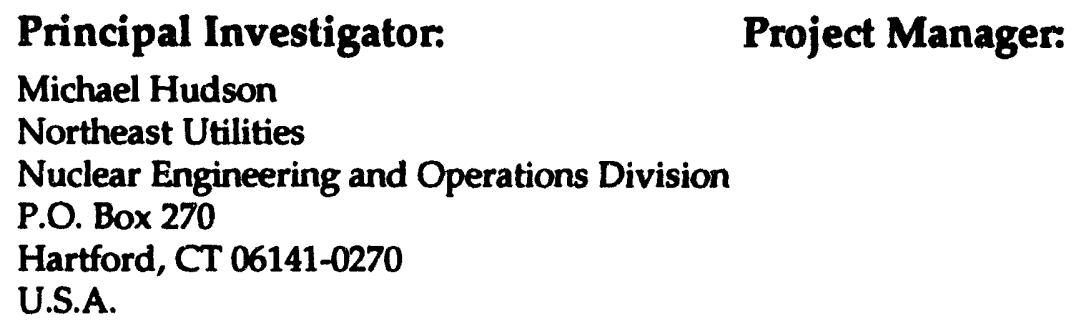

Objectives: Describe the ALARA efforts at Northeast Utilities and the results from elevated $\mathrm{pH}$, zinc injection, decontaminations, electropolishing, etc.

Comments: An aggressive chemistry and materials ALARA program was initiated at NE Utilities in 1986. It included:

- Elevated pH coolant chemistry control at MP3 (PWR)

- Zinc injection (GEZIP) at MP1 (BWR)

- Decontaminations, SG channel head electropolishing, and cobalt source removal

Millstone 3 End-Of-Cycle-3 Results (3.7 EFPY):

- Radiation fields remain low

- No evidence of adverse effects on I-600

- Continuing uncertainty about adverse effects of $\mathrm{Li}$ on high burnup zircaloy oxidation

- Standard coordinated pH 6.9 for cycle 4 and the future until

- more information on cladding limitations

- And/or fuel load with more corrosion resistant cladding

Millstone 1 Results After Decontamination and 2 Cycles of GEZIP:

- Recontamination dose rates leveled out at $50 \%$ less than without GEZIP

- Manageable side effects due to Zn-65 Production

- dissolution during shutdown

- food chain incorporation

- personnel monitoring and detectability

- extra waste curie load

- zinc depleted in $\mathrm{Zn}-64$ (GEZINC) is now being tested to reduce $\mathrm{Zn}-65$ production

Remarks/Potential for dose limitation: Other Chemistry ALARA Efforts at NU:

- Subsystem and SG channel head decons

- Early boration during shutdowns

- Acid reducing nickel clean up during start up after SG replacement at Millstone 2

- Modified elevated pH coolant chemistry control

- Participation in PWR Zinc Injection Program 


\section{BNL ALARA Center Data Base}

U.S.A.

Summary

- Two cycles of operation with zinc injection at Millstone 1 proved successful in reducing worker radiation exposure.

- Two cycles of operation with elevated pH at Millstone 3 proved successful in controlling the increase of SG channel head dose rates. However, fuel cladding oxidation concerns have led to a temporary respite in this program.

- Activities such as decontamination, surface treatment, and cobalt source removal programs, in conjunction with the coolant chemistry programs, will continue to be evaluated as means to reduce occupational radiation exposure at $\mathrm{NU}$ nuclear plants.

References: Hudson, M.J., "An Update On Chemistry Related Dose Reduction Efforts at Millstone Nuclear Generating Stations," Radiation Field Control Seminar, Electric Power Research Institute, Seattle, Washington, 1993.

Duration: from: 1986 to: 1994

Funding: N/A

Status: In progress

Last Update: January 5, 1994 


\section{SURFACE CHARACTERIZATION OF THE STEAM GENERATOR} CHANNEL HEAD FOLLOWING MECHANICAL/ ELECTROPOLISHING AT MILLSTUNE POINT UNIT 2

Keywords: CONTAMINATION PREVENTION; SURFACE CONDITIONING; MECHANICAL POLISHING; ELECTROPOLISHING; MILLSTONE

\section{Principal Investigator:}

John Perock

Westinghouse Electric Corporation

Nuclear Technology Division

Box 355

Pittsburgh, PA 15230-0355

U.S.A.

Phone: 412-374-5788
Project Manager:

Howard Ocken

Electric Power Research Institute

3412 Hillview Avenue

P.O. Box 10412

Palo Alto, CA 94303

U.S.A.

Phone: 415-855-2055

Objectives: The Surface Roughness Measurement Program for Millstone Point Unit 2 was developed to investigate the effects of mechanical polishing versus electropolishing with respect to surface roughness.

Comments: Under the auspices of EPRI, Westinghouse performed nondestructive surface roughness measurements on portions of the Millstone Point Unit 2 replacement steam generator channel heads. In preparation for service, Northeast Utilities performed pre-service surface conditioning of the replacement steam generator channel heads, namely, mechanical polishing/electropolishing. The results of this program will aid in determining whether a relationship exists between the surface roughness and activated corrosion product deposition.

Remarks/Potential for dose limitation: The data analysis of the surface roughness measurements performed at Millstone Point Unit 2 showed that the effectiveness of the electropolishing process on the divider plate was less than that on the channel head bowl and stay cylinder, which are weld overlay surfaces. This was due to the difference in the metallurgical surface structure of the weld overlay and the wrought $304 \mathrm{~L}$ stainless steel divider plate. During electropolishing of the weld overlay surfaces, the ferrite stringers were preferentially removed as compared to the surrounding surface structure. In addition, the electropolishing process removed or reduced the larger asperities, i.e., metal folds and scratches, caused by the mechanical polishing. This resulted in a smoother surface with respect to the average roughness parameter, $R_{a}$. An evaluation of the roughness data showed that the electropolished weld overlay surfaces were smoother than the mechanically polished surfaces with a statistically significant confidence level $(>=99 \%)$.

References: Perock, J.D., "Surface Characterization of the Steam Generator Channel Head Following Mechanical/Electropolishing at Millstone Point Unit 2," Radiation Field Control Seminar, Electric Power Research Institute, Seattle, Washington, 1993.

Duration: from: 1992 to: 1993

Funding: N/A

Status: Completed

Last Update: January 12, 1994 


\section{CHROMIUM TREATMENT OF RHR PIPING}

Keywords: CONTAMINATION PREVENTION; SURFACE PRETREATMENT; SURFACE CONDITIONING; RESIDUAL HEAT REMOVAL SYSTEM; DIABLO CANYON PLANT; CHROMIUM

\author{
Principal Investigator: \\ Roger Asay \\ Radiological \& Chemical Technology \\ 1700 Wyatt Drive, Suite 16 \\ Santa Clara, CA 95054 \\ U.S.A.
}

Phone: 408-982-0601

\author{
Project Manager: \\ Howard Ocken \\ Electric Power Research Institute \\ P.O. Box 10412 \\ Palo Alto, CA 94303 \\ U.S.A.
}

Phone: 415-855-2055

\section{Objectives:}

1) Investigate feasibility of using phosphoric acid based chromium plating bath to improve process application

2) Develop a range of acceptable chromium plating parameters for treating plant components

3) Evaluate effectiveness of surface pretreatments to mitigate activity buildup on out-of-core components

4) Scale-up stabilized chromium pretreatment process to full size plant components

Comments: With the positive results obtained in the Doel-2 coupon testing for surface pretreatment using chromium films, a full-scale application program was initiated. This program involved pretreating surfaces of RHR replacement piping at the Diablo Canyon Plant. This new stainless steel piping is 8-inch nominal and was installed during the 1993 refueling outage.

Both chromium and stabilized chromium films were applied to two different sections of replacement piping. A third section of the piping was left in the electropolished only condition while all the remaining pieces were electropolished and pre-oxidized. The electropolished section will serve as the "reference" surface. The pre-oxidation process is the RCT process as is typically applied to boiling water reactor primary system piping. Thus, there are four distinctly different surface treatments in the plant which will be monitored for activity buildup over the next two fuel cycles. Both gross gamma and gamma spectrographic measurements will be made at each opportunity to access the piping.

\section{Remarks/Potential for dose limitation:}

- Piping exposed to reactor coolant for only about 36 days at low temperature $\left(\sim 140^{\circ} \mathrm{F}\right)$

- Gamma spectroscopy measurements made approximately $\mathbf{4 6}$ days after system was removed from service

- Co-58 was by far the predominant nuclide (>95\%), with only trace levels of Co-60, Mn-54, and $\mathrm{Fe}-59$

- Only small differences in activity buildup were observed due to the short exposure period

- General trend of activity buildup correlates with the various surface pretreatments (i.e., stabilized chromium pipe had the lowest buildup and the as-received pipe had the highest buildup) 
U.S.A.

H-203

References:

Asay, R.H., "Chromium Treatment of RHR Piping," Radiation Field Control Seminar, Electric

Power Research Institute, Seattle, Washington, 1993.

Asay, R.H., "Activity Pickup by Coated Coupons Exposed in the Doel Reactor," Radiation Field Control Seminar, Electric Power Research Institute, Seattle, Washington, 1993.

Duration: from: 1993 to: 1994

Funding: N/A

Status: In progress

Last Update: January 12, 1994 


\section{ON-LINE MONITORING OF DOSE RATES AND SURFACE ACTIVITY DURING THE CYCLE 17 SHUTDOWN OF RINGHALS 2}

Keywords: OPERATIONAL AND MAINTENANCE TECHNIQUES; SHUTDOWN CHEMISTRY; DOSE RATES; RINGHALS 2

\section{Principal Investigator:}

Per Aronsson

Vattenfall AB

Ringhals

S-43022 Vaeroebacka

SWEDEN

Phone: 46-340-667190

\author{
Project Manager:
}

Objectives: Monitor in detail and collect data for the 1993 outage in Ringhals 2.

Comments: The shutdown of Ringhals 2 after cycle 17 in May 1993 was conducted according to the EPRI guidelines for PWR shutdown chemistry. The plant was kept at acidic reducing conditions for some 48 hours. Half of this time was spent at $86^{\circ} \mathrm{C}\left(187^{\circ} \mathrm{F}\right)$. After addition of hydrogen peroxide, an oxidizing clean-up with RCP-operation was run for 25 hours. The shutdown was monitored in great detail by frequent analyses of chemical and radiochemical parameters in the reactor coolant water. When the shutdown was completed, the routine gamma scan of various components in the plant was performed. In addition, crud sampling from four fuel assemblies for chemical and radiochemical analysis also was performed. The reduction in dose rates and surface activity on the excore surfaces is small, within $5-10 \%$. These findings are in agreement with the amount of activity released during the reducing phase. From the data collected, it can be concluded that some $50 \%$ of the gamma source strength in the reactor coolant system reside on the stainless steel surfaces. The steam generator tubing holds $10 \%$ and the fuel some $20 \%$. The remaining $20 \%$ were released and removed from the system during shutdown.

Remarks/Potential for dose lir.itation: The 1993 shutdown removed some $20 \%$ of the total gamma source strength from the reactor coolant system, but we removed very little of the gamma source strength on the RCS excore surfaces. The basis for this statement is the dose rate and gamma scan measurements plus the release during the reducing phase. Extending the time with reducing conditions would probably improve the result, since the release rate of Co-58 was stable at the end of the reducing phase. Zion 2 recently reported substantial dose rate reductions, but they used several weeks at reducing conditions to achieve this. With the dose rates and occupational doses we have had in Ringhals 2, it has not been judged necessary to spend that time to reduce the dose rates. Possible future repair operations and new, stricter rules for occupational exposure may force us to reconsider the implementation of an extended reducing phase. It is most likely that the majority of Co-58 released (some $80 \%$ ) in the shutdown originates from the fuel cladding and so does at least $50 \%$ of the Co-60. The decrease of the Co-60 release through the years indicates that we have decreased the supply of cobalt to the reactor system. 


\section{BNL ALARA Center Data Base}

References: Aronsson, P.O., Bengtsson, B., Bjornkvist, L., and Granath, G., "On-Line Monitoring of Dose Rates and Surface Activity During the Cycle 17 Shutdown of Ringhals 2 1993," Radiation Field Control Seminar, Electric Power Research Institute, Seattle, Washington, 1993.

Duration: from: 1993 to: 1993 Funding: N/A

Status: Completed

Last Update: January 12, 1994 


\section{CORROSION PRODUCTS BEHAVIOR IN FRENCH}

\section{PRESSURISED WATER REACTOR DURING SHUTDOWN OPERATION}

\section{Keywords: OPERATIONAL AND MAINTENANCE TECHNIQUES; SHUTDOWN CHEMISTRY; CORROSION PRODUCTS; FRENCH PWRS}

\section{Principal Investigator:}

Project Manager:

Serge Anthoni

Commissariat a L'Energie Atomique

Fuel Research Department

13108 Saint Paul Lez Durance, Cedex

FRANCE

Phone: 33-4225-7954

Objectives: The objectives of the experimental program are:

1) Primary water measurements

- volumetric activity of corrosion products by gamma spectrometry

- concentration of chemical elements by $X$-ray fluorescence

2) Deposited activity measurements with a portable gamma spectrometer

- on steam generator tubing

- on primary pipes

3) Measurements were carried out during 20 shutdowns for refueling (900 MWe PWRs)

Comments: During shutdown operation, cooling and injection of boric acid modify $\mathrm{pH}$ of the primary coolant leading to a significant increase in the activity of corrosion products. The modification from reducing to oxidizing conditions of the primary water produces a significant increase in cobalt isotope activity. The separate effects of cooling and oxygenation are quantified and studied. Analysis of concentrations and activities of corrosion products in the primary coolant enabled us to identify their origin.

Remarks/Potential for dose limitation: The evolution of contamination of the steam generator tubes and primary pipes using gamma spectrometry measurements during more than 20 shutdowns lead to the following conclusions:

- No significant reduction of out-of-core deposited activities occur during cooldown.

- The majority of the Co-58 and Co-60 activity released into the primary water come from the dissolution of in-core deposits ( $\mathrm{Ni}$ or $\mathrm{NiO}$ ).

- Aeration at temperatures $>90^{\circ} \mathrm{C}$ increases the Co-58 deposited on the out-of-core surfaces.

- The use of $\mathrm{H}_{2} \mathrm{O}_{2}$ reduces the outage critical path.

References: Anthoni, S., Ridoux, P., and Caramel, C, "Coirosion Products Behavior in French Pressurised Water Reactor During Shutdown Operation," Radiation Field Control Seminar, Electric Power Research Institute, Seattle, Washington, 1993.

Duration: from: 1992 to: 1994

Funding: N/A

Status: In progress

Last Update: January 12, 1994 
PWR STARTUP AND SHUTDOWN CHEMISTRY GUIDELINES

\section{Keywords: OPERATIONAL AND MAINTENANCE TECHNIQUES; \\ COOLANT CHEMISTRY; STARTUP CHEMISTRY; SHUTDOWN CHEMISTRY; CHEMISTRY GUIDELINES}

Principal Investigator:

Gary Brobst

GEBCO Engineering, Inc.

P.O. Box 1736

Sebrstopol, CA 95473

U.S.A.

Phone: 707-823-5237

Objectives: Develop PWR startup and shutdown chemistry guidelines.

Comments: The following guidelines originated from the study of industry data and experience by an ad-hoc committee formed by several utilities and EPRI.

Technical Basis for Shutdown Chemistry Control

- Field data did not strongly defend intensive or impacting chemistry controls during shutdown to reduce exposure rates

- Laboratory research indicated mildly acidic conditions would not likely affect long-term, Co-60 rich deposits that control plant exposure rates

- Some field data suggested that lack of chemistry control during shutdown may lead to release of particulate corrosion products and increased plant exposure rates

- The committee finally concluded that guidelines could identify the most appropriate shutdown chemistry scheme, though the technical basis was problem-avoidance, not radiation field reduction

\section{Remarks/Potential for dose limitation:}

Principles of Refueling Cold Shutdown Chemistry Control

1) Control reactor coolant $\mathrm{pH}$ during cooldown: Chemistry personnel should take measures to prevent increasing the alkalinity of the reactor coolant during cooldown. This is done by:

2) Maximizing the time with at least one reactor coolant pump operating.

3) Monitor coolant chemistry and maintain adequate cleanup capability.

4) Maximize letdown purification flow.

5) Maintain reducing conditions.

6) Ensure conditions in decay heat removal system do not adversely impact the chemistry of the RCS when mixed.

7) Create acid-oxidizing conditions to provide controlled solubilization of radiocobalt.

8) Reduce dissolved hydrogen to $<5 \mathrm{cc} / \mathrm{kg}$ prior to opening the RCS.

References: Brobst, G., "PWR Startup and Shutdown Chemistry Guidelines," Radiation Field Control Seminar, Electric Power Research Institute, Seattle, Washington, 1993.

Duration: from: 1992 to: 1994

$$
\text { Funding: N/A }
$$

Status: In progress 


\section{UPDATE ON DOSE RATES IN SIEMENS-DESIGNED PWRS}

\section{Keywords: CONTAMINATION PREVENTION; OPERATIONAL AND MAINTENANCE TECHNIQUES; DOSE RATES; SIEMENS; STELLITE REDUCTION; WATER CHEMISTRY}

\section{T. Marchl \\ Siemens AG KWU \\ Freyeslebenstr. 1 \\ D-91058 Erlangen \\ GERMANY}

Principal Investigator:

\section{Project Manager:}

R. Riess

Siemens AG KWU

Freyeslebenstr. 1

D-91058 Erlangen

GERMANY

Objectives: Investigate

1) Radiation fields in Siemens/KWU PWRs

2) Influence of the cobalt replacements on Co-60 activity concentration in the coolant and on the system surface

3) Comparison of Co-60 and Co-58 concentration levels

4) Overview on the occupational radiation exposures

\section{Comments:}

- An improvement was shown going from $\mathrm{pH} 6.9$ (at $300^{\circ} \mathrm{C}$ ) to $\mathrm{pH} 7.2-7.4$ and further at plants with low cobalt inventory

- 1991 conclusions were: Radiation field will be reduced by using cobalt-free hardfacing materials and by operating with the "modified" B/Li chemistry

Results Drawn From Dose Rate Development at 7 Siemens PWRs

- The plant starting to operate at $\mathrm{pH} 6.9\left(300^{\circ} \mathrm{C}\right)$ (coordinated B/Li chemistry) continues to see a slight increase in radiation field

- The plant starting to operate with "modified" B/Li chemistry seems to have reached an equilibrium situation after 4 years

- All plants with cobalt replacements are operating with dose rates of $<=0.5 \mathrm{mSv} / \mathrm{h}$

Remarks/Potential for dose limitation: All data available at Siemens/KWU confirm the Stellite replacement concept. To summarize:

- Radiation fields reduce with Stellite reduction

- Co-60 on surfaces reduces with Stellite reduction

- Coolant Co-60 reduces with Stellite reduction

- Coolant Co-60 correlates with Co-60 on surfaces

- Co-58 on surface: no correlation with Stellite reduction

- Coolant Co-58 does not correlate with Stellite reduction

References: Marchl, T. and Riess, R., "Update on Dose Rates in Siemens-Designed PWRs," Radiation Field Control Seminar, Electric Power Research Institute, Seattle, Washington, 1993.

Duration: from: 1991 to: 1994

Funding: N/A

Status: In progress

Last Update: January 13, 1994 


\section{DOSE RATE TRENDS AND CHEMISTRY AT SIEMENS-DESIGNED BWRS}

Keywords: CONTAMINATION PREVENTION; OPERATIONAL AND MAINTENANCE TECHNIQUES; DOSE RATES; SIEMENS; STELLITE; HEATER DRAIN

\section{Principal Investigator:}

T. Marchl

Siemens AG KWU

Freyeslebenstr. 1

D-91058 Erlangen

GERMANY

Phone:

\section{Project Manager:}

R. Riess

Siemens AG KWU

Freyeslebenstr. 1

D-91058 Erlangen

GERMANY

Phone:

Objectives: Investigate the dose rate trends and chemistry at Siemens-designed BWRs.

Comments: Current Status:

- All plants were operating with Normal Water Chemistry (NWC)

- None of the plants has considered Hydrogen Water Chemistry or Zinc Injection

- As far as there are data available the conclusion cannot be drawn that there is a remarkable influence of water chemistry on the $\mathrm{Co}-58$ and $\mathrm{Co}-60$ activity concentrations. However, the material concept seems to have a major influence on these values.

Remarks/Potential for dose limitation:

Conclusions from Occupational Radiation Exposures and from the Dose Rate Measurements:

- The plant with external recirculation piping has the highest radiation fields and the highest exposure

- Forward pumped units show higher radiation levels

- However, cascading or forward pumping of heater drains has no influence on personnel exposures

- Stellite replacement is most effective in reducing radiation fields and exposure rates

Two major steps can be identified in order to reduce radiation fields and occupational radiation exposure in Siemens/KWU BWRs:

- Replacement of the external recirculation piping

- Partial replacement of cobalt-base alloys in the RPV

References: Reitzner, U., Marchl, T., and Riess, R., "Dose Rate Trends and Chemistry at Siemens-designed BWRs," Radiation Field Control Seminar, Electric Power Research Institute, Seattle, Washington, 1993.

Duration: from: 1992 to: 1994

Status: In progress
Funding: N/A

Last Update: January 13, 1994 
APPENDIX 


\section{Introduction to ACE and ACEFAX}

In addition to being periodically published in NUREG/CR-4409 reports, the information on dose redurtion research and health physics technology projects gathered by the ALARA Center are available through two computerized systems, ACE and ACEFAX. ACE stands for ALARA Center Exchange. It is an on-line database system accessible via computer, modem, and the appropriate communications software. ACEFAX denotes our ALARA Center Exchange interactive fax retrieval system. By means of a fax machine with a handset (as opposed to computer fax boards), one can instruct ACEFAX to fax the information of interest to oneself. We will proceed to describe these two systems in detail.

\section{ACE}

Any new, pertinent information from published reports, conference proceedings, personal contacts, and other sources arriving at the ALARA Center is first summarized and then entered into our ACE electronic database system (hereby referred to simply as ACE). Thus, this medium contains the most up to date information available from the ALARA Center at any time. ACE is actually composed of a total of nine distinct databases, each focusing on different ALARA issues. The databases and their contents are:

\section{BIB $\quad 1500$ abstracts of published articles related to dose reduction and ALARA \\ DOSES current radiation dose exposure levels for workers at US nuclear power plants \\ HPTECH health physics technology - applied efforts at plants to reduce dose levels \\ JOBS lessons learned from high dose jobs at plants}

NEWS current events from journals, newletters, etc. in dose reduction and ALARA

PLANTS responses by plants on the usefulness and efficacy of new processes and practices

PRACTICE cur. int administrative and management techniques to reduce dose levels

PROCESS current engineering and scientific techniques to reduce dose levels

RESEARCH latest research findings on ways of reducing occupational doses in plants
ACE is organized on an IBM PS/2 with the commercial database software Q\&A, produced by the Symantec Corporation. It connects to the outside world by modem and the software CLOSE-UP. In order to access ACE, one needs \& PC compatible computer with a modem and the communications software CLOSE-UP 5.0, a commercial product available from the Norton-Lambert Corp. (For details on obtaining CLOSE-UP 5.0, see p. A-21.) CLOSE-UP is a remote control program that allows a person to use $A C E$ as if one is sitting in front of the ALARA Center IBM PS/2 computer. It sets up the user's computer as a terminal (remote) and the ALARA Center computer as the controlling entity (host).

Once the communication link between the host and remote is established, a menu will be displayed on the user's computer screen. (See the ACE Reference Guide on p. A-23.) For the sake of simplicity and ease of use, only four core commands have been defined for ACE. The commands allow the user to: 1) look sequentially at the records (often referred to as data forms, documents, or information sheets) of any of the 9 databases in ACE, 2) select a topic of interest through the use of keywords, 3) print the record on the screen, and 4) return to the menu from anywhere in the system.

\section{ACEFAX}

After the new information to the ALARA Center has been entered electronically into ACE, the next step is to produce a hard copy of the information. Records from the HPTECH, JOBS, NEWS, and RESEARCH databases are put into bite size documents of 1 or 2 pages designed to capture the main points and conclusions of the original report and provide a source for further information in an easy to read and pleasant looking format. The documents are then put on our ACEFAX system (hereby referred to simply as ACEFAX).

ACEFAX complements the ACE system in the distribution of ALARA Center information. It allows a person to access the four aforementioned databases plus some general documents by means of a regular fax machine with a handset (not from computer fax boards, however). ACEFAX was set up with the belief that more people have (or prefer to use) s?: machines than computers. The main advantage be..? the ease of use, while sacrificing some of the flexibility of ACE. 
When a person calls from a fax machine, ACEFAX responds with a voice message and brief instructions on how to obtain the documents. Basically, the user enters the number of the document of interest and ACEFAX will send that document to the user's fax machine. Document " 12 " contains the list of all documents available on ACEFAX. The document numbering system is as follows:

1 to 100 general

101 to 500 health physics technology database

501 to 1000 jobs database

1001 to 2000 research database

2001 to 3000 reserved for future use

3001 to 4000 news database
Note that the numbers assigned to the health physics technology and research database documents are related to the numbering of the projects published in the NUREG/CR-4409 (vol. 4 \& 5) report. For example, projects H-195 and R-385 from NUREG/CR-4409 correspond to documents 195 and 1385 in ACEFAX.

\section{Phone Number for ACE AND ACMTAX}

ACE $\quad 516-282-3481$

(call from computer with modem and CLOSE-UP 5.0)

ACEFAX 516-282-7361

(call from the handset of a fax machine) 


\section{BROOKHAVEN NATIONAL LABORATORY ALARA CENTER ACEFAX SYSTEM}

Requesting ALARA Documents Using Your Fax Machine
For the fastest service, you don't even need a computer. The ACEFAX system will fax information to you immediately. The service is available 24 hours a day. Here's how to use it:

1. Pick up the handset on your facsimile machine and dial (516) 282-7:161. Llaten with the handset - do not hang up after dialing.

2. A voice will answer and give you instructions. Using the touchtone pad of your fax machine, you will enter the number of the document you want from the attached list. You may order up to five documents per session. To correct an error, press the astertisk key $\left(^{*}\right)$ and enter the number again.

3. When you are prompted by the voice, press the "START/COPY" or "RECEIVE" button on your fax machine (usually the green button). You may then hang up the phone. You will begin to receive the documents within a minute.

Note: If you recelve errors, your fax machine and ours may be incompatible. Fill in the form below and mail it to the ALARA Center, Bullding 703M, Brookhaven National Laboratory, Upton, NY 11973. We will mail the documents to you.

\section{If You Don't Have a Fax Name Machine Company Address}

City, State, Zip

Please send the following documents:

Please check one: I don't have a fax machine. I was not able to make a successful connection to ACEFAX. 


\section{BNL ALARA Center \\ List Of Documents On ACEFAX}

$516 / 282-7361$

\section{General Documents}

10

ALARA Notes Nc. 8 (22 pages) LIST OF DOCUMENTS ONACEFAX (15 pages) ACE Manual (Ravision 5) (4 pages) ALARA Notes No. 9 (19 pages) Dollar Worth Of A Person-Rem For US Utilities: Updated 1994 Values (1 page) A Survey Of Doses To Worker Groups In The Nuclear Industry (13 pages) Collective Dose Per Reactor For Selected Countries (1 page) Registration Form For ACE (1 page) Bournemouth Meeting On Water Chemistry Of Nuclear Reactor Systems \#6 (10 pages) More Details On Documents On ACEFAX (20 pages) The Program Of The ALARA Center At Brookhaven National Laboratory (15 pages) BWR and PWR Collective Radiation Exposure 3-Year Rolling Average Tables For 1992 (2 pages)

Third International Workshop On Implementation Of ALARA At Nuclear Power Plants - May 1994 (Information and Registration Form) (4 pages)

Third International Workshop On Implementation Of ALARA : Agenda (13 pages)

Subject Index For Jobs Database (1 page)

Subject Index For Health Physics Technology Database (2 pages)

Subject Index For Research Database (4 pages)

Subject Index For News Database (6 pages)

Collective Dose And Electricity Produced: U.S. Nuclear Power Plants (1 page)

\section{Documents From The Health Physics Technology Database}

Innovative Approaches At TMI-2

Identify All Cobalt Contributors In PNPS

Evaluate Hot Spots Associated With Spent Fuel Pool System

Surrogate Laser Disc Plant Tour System

Maintain Radiological Evaluation Factors

Replace Feedwater Control Valve Trim With Non-Cobalt Design

Recirculation Pump Cobalt Elimination

Fuel Improvements To Reduce Cobalt Source

Establish Chemical Decontamination Strategy 
Evaluate Zinc Addition To Reactor Feedwater (GEZIP)

148 Reactor Control Blade Management Considering ALARA

149 Evaluation, Possible Reduction In Operation And Testing Of CRDs To Reduce Cobalt Input

150 Project MINDOS

151 Study On The ALARA Policy In Korea

152 Reduction Of Time, Exposure, And Cost Through Plant Decontamination

153 Reactor Cavity Decontamination At V. C. Summer

154 Use Of Respirators And Dose Expansion

155 Optimizing Worker Protection: A Practical Application Of Risk Analysis

156 Advanced Radiation Worker Training Program And Laboratory

157 ALARA Aspects Of The Calvert Cliffs Pressurizer Repair Project

158 ACE - ALARA Center's Dose-Reduction Information System

159 An Effective ALARA Awareness Program

160 An ALARA Training Program For Design Engineers

161 System Decontamination Of RWCU System

162 Resistance Temperature Detector Bypass System Elimination

$163400 \mathrm{R} / \mathrm{hr}$ Hot Spot Removal At Cooper Nuclear Station

164 Innovative Shieiding

165 Removal Of Control Rod Drive Through Robotics

166 Data Acquisition On PWR Contamination

167 Panthere RP: A Tool For Evaluating Dose Rates

168 The Ingredients Of A Utility's Dose Reduction Program

169 Methods Used To Achieve Outage Goals At Diablo Canyon

170 Radiation Exposure Reduction Program At Mitsubishi Heavy Industries

171 Clamshell Nozzle/Pipe Shielding

172 Feedwater Nozzle Thermal Sleeve Hydrolyzing

173 Snubber Positioning Fixture

174 Removal Of Fine Chrome Particulate From Spent Fuel Pools By Means Of A Radial Lamella

175 A Method For Optimizing The Use Of Respiratory Protection in Radiation Areas

176 Indian Point 2 Sub-System Decontaminations

177 National Demonstration Of A Full RCS Chemical Decontamination

178 Plant E.I. Hatch Chemical Decon 1991

179 Chemical Decontamination Of The Residual Heat Removal System

180 Ontario Hydro Decontamination Experience

181 Resource Management As An ALARA Tool

182 PWR Upper/Lower Internals Shield

183 Internal Dose, Respiratory Protection And Revised 10CFR20 At Davis-Besse Nuclear Power Station

184 Zion Unit 2 Cycle 12 Shutdown And Early Boration Results

185 Health Physics Services On The Platform At Salem Using ROMMRS

186 Chemical Decon Of Systems: Results And Problems

187 An Automated Program Implementing New 10CFR20 Requirements At Southern Nuclear Plants 
Steam Generator Replacement Project At North Anna Power Station

S/G Replacement At Beznau 1: Experience And Results In Radiological Protection

Partners In Performance: An ALARA Perspective Steam Generator Snubber Elimination

Future Power Stations In The United Kingdom: Designing For Low Doses A Team Approach For The Management Of Radioactive Liquid Effluents ALARA And Work Management Radiological Assessment Of Decommissioning At Fort St. Vrain Personnel Radiation Exposure Reduction During Remote Stud Handling At Indian Point 2 Replacement Of RWCU Piping With State-Of-The-Art Materials Evaluation Of Zircaloy Fuel Clad Oxidation At Millstone 3 PWR

An Update On Chemistry Related Dose Reduction Efforts At Millstone Nuclear Generating Stations

202

Surface Characterization Of The Steam Generator Channel Head Following Mechanical/ Electropolishing At Millstone Point Unit 2

203

Chromium Treatment Of RHR Piping

204 On-Line Monitoring Of Dose Rates And Surface Activity During The Cycle 17 Shutdown Of Ringhals 2

205 Corrosion Products Behavior In French Pressurised Water Reactor During Shutdown Operation

206 PWR Startup And Shutdown Chemistry Guidelines

207 Update On Dose Rates In Siemens-Designed PWRs

208 Dose Rate Trends And Chemistry At Siemens-Designed BWRs

\section{Documents From The Job Database}

501 Replacement Of Waste Collector Filter Septa

502 Welding And Inspection Of Pressurizer

503 Repair Of Steam Dryer

504 Decontamination Of Reactor Cavity

505 Replacement Of Filter Septums

506 Remote Control Rod Drive Handling System

507 Core Grid Support Repair

508 Heat Exchange Decontamination

509 Modification Of Reactor Temperature Detector System

510 Turning Vanes Replacement

511 Decontamination Of RWCU Using The Cord Process

512 Feedwater Sparger Replacement

513 Work Inside Reactor Vessel

514 Vacuum Cleaning Of Steam Generators

515 Decontamination Of Primary Coolant Pumps 
516 Replacement Of Incore Monitors

517 Desludging And Decontamination Of Radwaste Aisles

518 Installation Of Insulation Cartridges

519 Shot Peening Of The Hot Leg Tubes Of A Steam Generator

520 Shipment Of Spent Fuel Assemblies

521 Radiation Protection Surveys And Job Coverage

522 Replacement Of a Pump In a High Radiation Area

523 Insulation Replacement On Recirculation Piping And Valves

524 Replacement Of Insulation On Main Steam Piping

525 Removing Scaffoiding From Drywell

526 Replacement Of Reactor Recirculation Pump Cooler

527 Replacement Of a Flange Gasket

528 Repair Of Main Steam Sensing Line Supports

529 Replacement Of Steam Generators

530 Replacement Of Primary Pipes Inside Containment

531 Shot Peening Of The Cold Leg Tube Of Steam Generator

532 Up-Flow Conversion

533 Additional Experience From Shot Peening

534 Replacement Of Reactor Coolant System Valve Internals

535 Decontamination Of The Drywell

536 Valve Repair In Reactor Water Cleanup System

537 Repair Of Tube Bellows Flange

538 RWCS Pump Reassembly

\section{Documents From The Research Database}

1229 VERALIGHT - A New Light Manipulator For Steam Generator Inspection

1250 Development, Fabrication, And Test Of The ODEX-3 Maintenance Vehicle

1251 Source Book For Chemical Decontamination Of Nuclear Power Plants

1252 The Nature And Behavior Of Particulates in PWR Primary Coolant

1253 PWR Radiation Control Demonstration

1254 Field Tesis Of Radiation Control Techniques - 1

1255 Effect Of Surface Treatments On Radiation Buildup In Steam Generators

1256 Millstone 1 Zinc Injection Evaluation

1257 PWR Steam Generator Preconditioning Studies

1258 The Treatment Of Radioactive Ion-Exchange Resins

1259 PWR Corrosion Tests Using LOMI

1260 Crud Transport Chemistry

1261 Qualification Of Cobalt-Free Hardfacing Alloys For LWR

1262 Production Of NOREM Hardfacing Alloys

1263 Cobalt Replacement Guidelines

1264 BWR Cobalt Deposition Studies 
1265 Research Reactor Loop Water Chemistry Study

1266 Radiation Field And Dose Data Assessment

1267 Passivation And Surface Conditioning

1268 Feedwater Flow Element Improvement

1269 Coolant Chemistry And Radiolysis In Bolling Reactor Coolant

1270 On-Line Monitoring Techniques For Redox Potential, Hydrogen Concentration, and pH in Nuclear Reactor Coolant Circults

1271 In-Plant System For Continuous Low-Level Ion Measurement In Steam-Producing Water

1272 Resin Separability To Improve Polishing Under Morpholine AVT

1274 Oxygen Transport In BWR Cycles

1275 Remote Repair Technique For MSIVs

1276 Intellitorque : A System For Monitoring Root Cause Of MOV Malfunctions

1277 Using Ultrasonics To Avoid Check Valve Disassembly

1278 A "Wet Motor" Sealless Pump For Reactor Water Clean Up System In BWRs

1279 A Rotating UT System For Inspection Of Steam Generator Tubes

1280 The ALOK 3 Ultrasonic Inspection System

1281 Acoustic Leak Monitoring In Japan

1282 Use Of Vibration Monitoring To Assess Reactor Coolant Pump Integrity

1283 Improved Test Methods For Plant Protective Coating

1284 Automated Control Rod Drive Bolting Wrench System To Support Boiling Water Reactor Maintenance

1285 Measurement Of Oxide Film Released As Particles During The CAN-DEREM Decontamination Process

1286 "Wet Motor" Sealless Pump For Reactor Water Clean Up System In BWRs

1287 Reactor Water Cleanup (RWCU) Sealless Pump

1288 Exposure Reduction Measures In The Design Of Siemens/KWU PWR Plants

1289 Full System Decontamination Of The BR-3 PWR Plant

1290 Mitigation Of The Impact Of Reduced Radiation Exposure Limits On Nuclear Power Plant Operations

1291 Sources Of Cobalt-60 In The Primary Systems Of Pressurized Water Reactors

1292 Performance Of Iron Base Hardfacing Alloys Under Pressurized Water Reactor Conditions

1293 U.K. Program To Qualify Cobalt-Free Hardfacing Alloys

1294 Supplying Cobalt-Free Nuclear Valves

1295 An Examination Of Foreign Approaches To Controlling Radiation-Field Buildup In Boiling Water Reactors

1296 Guidelines For The Reductior, Of Cobalt From Reactor Systems

1297 BWR Radiation Field Trends

1298 Status Of Zinc Injection In Boiling Water Reactors

1299 Experience With Zinc Injection At Millstone 1

1300 Control Of Radiation Fields At Bolling Water Reactors By Reducing Iron Input

1301 Effect Of Preconditioning On Cobalt Corrosion Release Rates

1302 Radiation Field Issues In Switching To Hydrogen Water Chemistry 
Quallification Of Electropolishing For Replacement Steam Generators

1304 French Experience With Electropolishing Steam Generator Channel Heads

1305

Surface Pretreatment Of Primary System Components To Reduce Radiation Buildup

1306

Reducing Radiation Bulldup By Surface Coating Of Primary System Components

1307

PWR Primary Water Chemistry Guidelines - Revision 2

1308 Reduction Of Radiation Fields By Elevated pH Control At Millstone-3

1309

1310

1311

Loop Experiments On Zinc Injection Under PWR Conditions

Corrosion Control And Dose Rate Reduction

1312

Effects Of pH And LI On PWSCC Initiation And Growth

1313

Radioactivity Pick-Up By Carbon Steel And Stainless Steel In Slightly Oxidizing Lithiated Coolant

1314

Lessons Learned From Recent BWR Chemical Decontamination Applications

1315

Decontamination Of Beaver Valley Steam Generators Using The CAN-DEREM Process

1316

Full RCS Chemical Decontamination

1317

BWR Full System Decontamination

1318

PWR Coolant Chemistry Studies In Support Of Dose Reduction Using In-Pile Loops At MIT

Solubility Measurement Of Crud And Evaluation Of Optimum pH

Full Reactor Coolant System (RCS) Decontamination National Demonstration Plan

Full System Decontamination Of The BR-3 Plant

Future Developments in Processing Decontamination Waste

1322

Reduction Of Critical Path Time For BWR Recirculation System Decontaminations

1323

Improvements In The LOMI Decontamination Process

1324

Radiation Fields Trends And Control At French PWRs

Weldability Of NOREM For In-Situ Repair \& Replacement

High pH Operation At Swedish PWRS

Radiation Field Control By Early Boration During Shutdown At Beaver Valley Power Station

High pH Operation In ABB Combustion Engineering Plants

Reactor Coolant System Shutdown Chemistry And Nickel Management At H.B. Robinson Nuclear Project

1330 Zinc Injection At Millstone 1

The Effect Of Zinc On Corrosion And Dose Rate Control

TRACKER: An Absolute Tube-Position Detection And Tube Marking System

1334

BWR Underwater Disassembly/Assembly - Wetlift 2000

PWR Primary System Chemistry: Exprience With Elevated pH at Millstone Point Unit 3

Steam Generator Dosø Rates At Babcock \& Wilcox Reactors

Preconditioning Of PWR Steam Generators To Reduce Radiation Buildup

Welding Of NOREM Iron-Base Hardfacing Alloy Wire Products - Procedures For Gas Tungsten Arc Welding

1338 Endurance Tests Of Valves With Cobalt-Free Hardfacing Alloys

1339 Replacement Of Pins And Rollers In Irradiated BWR Control Blades

1340 Secondary Hydriding Of Defected Zircaloy-Clad Fuel Rods

1341 Testing Of An Organic Removal Process In BWR Radwaste Systems

1342 Evaluation Of Reactor Pressure Vessel Head Cracking In Two Domestic BWRs 
1343 Relationship Of Radiation-Induced Segregation Phenomena To Irradiation-Assisted Stress Corrosion Cracking (IASCC)

1344 Light Water Reactor Materials And Water Chemistry Studies At Halden

1345 PWR In-Pile Loop Studies in Support Of Coolant Chemistry Optimization

1346 The Effect Of Dissolved Oxygen In Lithiated Coolant

1347 Chemistry Parameters Influencing The Dose Rate Build-Up In BWR Plants

1348 Overview Of Activities For The Reduction Of Dose Rates In Swiss Bolling Water Reactors

1349 Operating Experience Of Japanese Improvement And Standardization BWRs And Behavior Of Radioactivity in Reactor Water

1350 Feedwater Iron Crud Reduction For Chinshan Nuclear Power Station

1351 Reactions Of Iron Crud With Metallic lons Under BWR Water Conditions

1352 Decomposition Of Hydrogen Peroxide In BWR Coolant Circult

1353 Full Primary System Chemical Decontamination Qualification Program

1354 Full System Decontamination And Countermeasures Against Recontaminatioil Of The Fugen Nuclear Power Station

1355 Electrochemical Corrosion Potential Measurement With A Rotating Cylinder Electrode In $288^{\circ} \mathrm{C}$ Water

1356 Effects Of Zinc Additions On The Crack Growth Rate Of Sensitized Stainless Steel And Alloys 600 And 182 In $288^{\circ} \mathrm{C}$ Water

1357 On-Line Measurement Of Particles In Reactor Water Of BWRs

1358 The Integrity Of Inconel Alloys In High Temperature Water Chemistry

1359 Enriched Boron Products

1360 Variabilities In The Calculation Of PWR Primary Coolant pH

1361 Construction And Operation Of An In-Pile Loop For BWR Coolant Chemistry Studies

1362 Water Chemistry During The.Shut-Down Of The Boiling Water Reactor Leibstadt

1363 Solubility Of Cobalt In Primary Circuit Solutions

1364 Statistical Analysis Of Reactor Water Data

1365 Mixed Oxide-Alloy-Water Systems Under LWR Conditions

1366 Maximum Allowable Chloride Levels On Stainless Steel Components At The Size Well 'B' PWR

1367 Inorganic Seed Materials For The Decontamination Of PWR Aqueous Wastes

1368 Easy Inexpensive Hydrogen Water Chemistry Predictive Methods

1369 Potential-pH Diagrams For Alloy-Water Systems Under LWR Condition

1370 In-Pile Loop Studies Of Close Reduction Technologies For PWRs And BWRs; Investigations Of Material Susceptibility To Cracking

1371 Evaluation Of Factors Affecting Radiation Field Trends In Westinghouse-Designed Plants

1372 The Mechanics And Kinetics Of Corrosion Product Release From Carbon Steel In Lithiated High Temperature Water

1373 Investigation Of The Chemical And Physical Properties Of Spinel Oxides

1374 Overview of The Impact Of Stellite Removal On Radiation Fields In KWU PWRs

1375 Activity Transport And Corrosion Processes In PWRs

1376 Feasibility Of On-Line Monitoring Of Stress Corrosion Cracking In Rotating Components

1377 Concept And Experience Of System Decontamination With CORD

1378 ELOMIX: A Better Way Of Handling The Waste From Decontamination 
BWR/5 Full-System Decontamination Feasibilly Study

1380 Moving From Ultra-Pure BWR Water To Plant-Tallored Water Chemistry

1381 Effects Of PH Of Primary Coolant On PWR Contamination

1382 Behavior Of PWRs in Spain Following Changes To Modifled Chemistry And Fuel Specifications

1383 Review Of Effect Of Lithlum On PWR Fuel Cladding Corrosion

1384 Shutdown Chemistry in Spanish Plants

1385 Effect Of Surface Treatment On Radioactivity Deposition On Stainless Steel Coupons Exposed In Dool 2

1386 Utility Approach To Radiation Fleld Reduction By Coolant Chemistry Control

1387 Low Picolinate LOMI - Update

1388 Decontamination Chemistry: Current lssues

1389 Resin Oxidation Process Improvements

1390 Development Of Full System Decontamination For BWRs

1391 SCE\&G Fuel Decontamination Qualification Program

1392 Pacific Nuclear Field Implementation

1393 Utility Decontamination Experience

1394 ABB Atom Prnject - ALARA 2000

Development And Use Of An In-Pile Loop For BWR Chemistry Studies

1396 Replacement Of Pins \& Rollers In Irradiated BWR Control Blades

1397 Cobalt Source Reduction - Control Rod Pin \& Roller Replacement

1398 Performance Of Iron-Base Hardfacing Alloys In Gate Valves Tested Under Simulated BWF Chemistry Conditions NOREM Wear-Resistant Alloys: An EPRI Program Update

The Effect Of Zinc On Carbon Steel And Stainless Steel In Lithiated Coolant Optimum Water Chemistry In Radiation Field Buildup Control Status Report On BWR Full System Decontamination

Activity Pickup By Coated Coupons Exposed In The Doel Reactor

\section{Documents From The News Database}

Preventing Erosion-Corrosion At Sizewell B

3002 How Finer Fitter Can Keep Exposures Down

3003 Enriched Boric Acid Promises Greater Flexibility For PWRs

3004 Control Rod Drive Removal And Installation Mechanism Saves Dose

3005 Steam Generator Pipe End Decon Saves Approximately 100 Person-Rem

3006 More On Strippable Coatings

3007 Effect Of Elevated Lithium pH On Inconel 600

3008 Conductivity During Early Life Important In Fuel Oxidation And Failure

3009 BWR Zinc Injection Update

3010 Protective Coatings For Radlation Control In Boiling Water Nuclear Power Reactors

3011 Designing For Maintainability 
3012 Plant Inspection Experience And The Equipment Needed

3013 Progrees In Radiation Control Technology

3014 Experlence With Elovated pH At Millstone Point Unit 3

3015 Full System Decontamination Results

3016 Recent Experience With Zinc Injection

3017 Coball Reduction Guidelines

3018 Proceedings: 1989 EPRI Radwaste Workshop

3019 Reduction Of Crtical Path Time For BWR Recirculation System Decontaminations

3020 Proceedings: Primary Water Stress Corrosion Cracking Workshop

3021 Implementing Coball-Free Alloys In Nuclear Plant Values

3022 Evaluation Of Iron-Based Hardfacing Alloys

3023 Update On Weldability Studies

3024 MintSub In Use At Con Edison's Indian Point 2

3025 Lightweight Torque Wrench Improves Bolting Maintenance

3026 Vac-Pac Technology: Safo, Clean, Efficient Vacuum Collection

3027 Acrylic Fbor Toppings Simplify Decontamination In Nuclear Facilities

3028 A Welding Arc Vilower

3029 Pipe And Tube Cutting

3030 Fuel Master Increases Capacity

3031 Looking For Steam Generator Leaks With Hellum

3032 Hall-Effect Helps

3033 Strippable Coating Provide Leak-Tight Integrity And Hot Particle Mitigation

3034 Effect Of Electropolishing. Preoxidation And Zinc On Buildup In BWR Recirculation Piping

3035 Electropolishing Minimizes Radbactivity Bulldup

3036 Chemical Decontamination In Germany

3037 Approaching Consensus On The Optimum pH For PWRs

3038 Collective Doses For Steam Generator Replacements

3039 Radionuclide Buildup In BWR Reactor Coolant Recirculation Piping

3040 Update On Full-System LWR Decontamination

3041 Video Camera Use Reduces Costs And Exposure

3042 Update On Primary Chemistry Guidelines For PWRs

3043 Electropollshing Steam Generator Channel Heads: The French Experience

3044 Current Thinking On Relative Importance Of Cobalt Reduction And Water Chemistry For PWRs

3045 The Effect Of Dissolved Zinc On The Transport Of Corrosion Products In PWRs

3046 Vessel Inspection Made Easy

3047 New Alloys Resist Wear Without Costly Cobalt

3048 New Lesson Plan Packages

3049 More On Mitsubishi's Undenwater Vehicle For Uitrasonic Vessel Inspection

3050 General Electric's New Inspection System Gives Inside Information On BWR RPV Welds

3051 Key Tagging For Security

3052 High-Capacity Filters 
Ontario Hydro Proposes Canning And Burying Candu Reactors

Strippable Coatings Help Reactor Cavity Decon

Can-Decon Makes A Strong Comeback As Can-Derem

Hot Spot Reduction Program At Braidwood

Doses _ecreasing At Ontario Hydro

Ontario Hydro - Preventative Measures Following An Overexposure Incident

Pacific Gas \& Electric Upgrades Radiation Monitoring

Employee Attitudes: The Key To Exposure Reduction At Oyster Creok

Electricite De France To Place Bulk Order For Steam Generator Replacement

French Thinking On The Comparative Merits Of Alloys 690 And 800

3063

BWR Zinc Injection

KWU Plans 54-Day Steam Generator Replacement

Aea Technology's 3D TV Equipment Shows Performance Benefits Over Conventional Television Mitsubishi's New Passive PWR

Maintaining Dose Histories In The United Kingdom

Conclusions Of The EPRI Workshop On BWR Zinc Injection

PWR Primary Water Chemistry Guidulines - Revision 2

3072

ICRP'S New Recommendations

3073

Repairing And Replacing Steam Generators At Soviet 1000 Mwe PWRs

3074 Beznau 1 Plans Steam Generator Replacement

3075 Aiming For Improved Steam Generator Rellability In Japan

3076 Comparisons Of Steam Generator Replacement Techniques

3077 Quick And Easy Adjustment For Values

3078 A Smaller Dosimeter

3079 Portable Test Bench For Snubbers, Pumps, And Steam Generators

3080 Special Cleaning Devices For Sellafield

3081 Farewell To The Mop And Bucket

3082 NRC Decision On Level Of Detail For Advanced Reactors

3083 Replacing The Pressurizer Heater Sleeves At Calvert Cliffs 2

3084 Crawling Around Byron

3085 From Reaction To Proaction - Taking The Preventative Approach

3086 Occupational Dose Reduction At NPP: Annotated Bibliography Of Selected Readings in Radiation Protsction And ALARA

3087 Combining Zinc Injection With Hydsogen Water Chemistry

3088 Update On Zinc Injection For BWRs

3089 Latest Results From Elevated Lithium Demo At Millstone-3

3090 Electronic Personal Dosimeter Heralds A Revolution In Legal Dosimetry

3091 Science Applications International's New Small Dosimeter

3092 Techniques For Dose Reduction

3093

Consequences Of Reduced Limits 
3094 Getting Exposures Down At Us Plants

3095 The Age Of The "Throwaway" Video Camera is Here

3096 Swedish Technology Provides Inside Knowledge Of US BWR Vessels

3097 Blbliography Of Selected Readings On Radiation Protection And ALARA

3088 NRC Tightens Radiation Exposure Limits

3099 Setting New Protection Standards For Radiation

3100 Occupational Doses in ABB Atom BWRs

3101 Video Cameras At Nuclear Plants

3102 Radiation Exposures At US Plants In 1990

3103 Full System Decontamination Workshop Planned

3104 Full System Decontamination Qualification Programs - PWR Studies

3105 Full System Decontamination Qualification Program - BWR Qualification Program

3106 Full System Decontamination Programs - Comparison Of Fuel in And Fuel Out

3107 Field Demonstration Of NOREM Wear - Resistant Alloys

3108 PWR Shutdown Chemistry

3109 Shutdown Radiation Fields At BWRs Using Hydrogen Water Chemistry

3110 Robotic Maintenance Systems For Nuclear Power Plants

3111 Expanding The Range Of Activities Performed Remotely At Nuclear Power Plants

3112 Scaffold Management - A New Era

3113 Managing Of The Aging BWR Control Rod Drive Mechanisms

3114 ALARA Reduction During CRDM Changeout And Rebuilding

3115 CRDM Worker Training

3116 Dustless Surface Preparation And Decontamination Systems For Concrete Floors

3117 Zinc Injection Helps Reduce Radiation Field Buildup In BWRs

3:18 Putting pH 7.2 Water Chemistry To The Test At French PWRs

3119 EPRI-Sponsored Technology Easing CRDM Change-Out Job At BWRs

3120 Information Exchange

3121 Collective Doses In European Light Water Reactors

3122 Computerized Dose Tracking

3123 Advanced Technologies

3124 Dose Reduction By Outage Planning, Strategy, And Architectural Arrangements

3125 Robotic Applications

3126 Dose Reduction During Inspection Of Germany PWRs

3127 Dose Trends In German PWRs

3128 Dose Reduction In Japan Atomic Power Company Plants

3129 Exposure Reduction At Shimane, Unit No. 2

3130 Steam Generator Replacement At Dampierre 1

3131 Work Planning And Organization

3132 Worker Training And Responsibility

3133 Planning For Ringhals 2 Steam Generator Replacement

3134 Swiss Experience With Zinc Injection And Soft Shutdown 
CRD Services

3136 Inspection Cameras

3137 Remote Inspection

3138 Heat Stress Monitor

3139 Alarm Ratemeter

3140 Camera System

3141 UT Imaging System

3142 RPV Stud Tensioning

3143 Factors Influencing Collective Exposure Trends

3144 The Challenge Of The 1995 Radiation Exposure Goals

3145 NRPB Opts For "Constraints"

3146 Bringing Robotic Tensioning To The U.S.

3147 World Nuclear Industry Handbook - 1992

3148 ALARAALARP: Working Well Before ICRP 60?

3149 Bar Code System

3150 Inspection Services

3151 Dosimetry Reduction

3152 Inspection Robot

3153 Inspection Robots

3154 Fluorescent Lamps

3155 Video Inspection

3156 SG Annulus Seal

3157 Standard Versus Hydrazine Water Chemistry In Vver-440

3158 Dose Reduction At Mcguire By Teledosimetry And Remote Communication

3159 Using Satellite Technology To Improve Steam Generator Eddy Current Inspections

3160 An Update On The Mechanical Stress Improvement Process

3161 Remote Operated Vehicles - A Driving Force For Improved Outages

3162 Winning The Battle Against IGSCC

3163 I.S.O.E. - An International Contribution To Keep Workers' Doses ALARA

3164 ALARA - An Historical And Global Perspective

3165 Instructions For Recording And Reporting Occupational Exposure Data

3166 ALARA Regional Conference: Region 1

3167 Applied Robotics Test Facility - A New Partnership For The Mobile Robotics Community

3168 Advanced Technologies Applied To Work Management

3169 Radiation Field Evaluations

3170 The Effect Of Chemical Additives On N-16 Carryover Under Simulated BWR Conditions

3171 Electropolishing of Replacement Steam Generator Channel Heads At Millstone-2 PWR

3172 Update On U.S Power Industry Exposures

3173 Remotec's All-Terrain Robots

3174 New Remote Radiation Surveillance System

3175 Instant Monitoring On Hand 
3177 Dose Control At China's First Nuclear Power Plants

3178 Candu Large Scale Fuel Channel Replacement Project: Individual \& Collective Dose Reduction By ALARA Integration

3179 Radiation-Field Control Manual -1991 Revision

3180 Nuclear Power Plant Resource Book - Vol. 2: BWR

3181 A Brief History Of Robots In The United States

3182 Trod Cleans Up At Nine Mile Point 1

3183 More Radiation Monitoring Backfits For The Future

3184 Designing Radiation Protection Into Sizewell B

3185 Frozen CO2 Pellets Process For Decontamination

31861991 Exposure Trends

3187 Control Blade Pin And Roller Replacement

3188 Improving Communications With Utility Personnel

3189 Depleted Zinc Evaluation At Fitzpatrick

3190 Decontamination Update

3191

BWR Radiation Fields With Hydrogen Water Chemistry

3192

Formation Of PWR Radiation Protection/ALARA Committee

3193

1992 Exposure Reduction Plants At Surny Power Station

3194

Repairing The Spent Fuel Coolant Pump At Surry: Operational Details Of A Job

3195

Improved Tld Badges

3196

Pilgrim's Progress Points The Way To The Cobalt Reduction

3197

Looking For Links Between BWR Hydrogen Water Chemistry And Increased Shutdown Dose Rates

3198 New PWR Guidelines Target Intergrenular Attack And Stress Corrosion Cracking In Steam Generators

3199 Water Chemistry And Dose Reduction: New PWRs

3200

Water Chemistry And Dose Reduction: Millstone 3 Experience

3201

PWR Primary Cnolant Chemistry And Dose Reduction

3202

Using Divers To Inspect And Repair The Torus Proper At Peach Bottom

3203

Scale Models - An Effective Tool For ALARA And Constructability Planning

3204

3205

New Developments In The Surrogate Tour System

3206

3207

3208

3209

Report On The 6th Bournemouth Conference On Water Chemistry

1992 Radiation Exposure Management Seminar Highlights

Steam Generator Strategy For Ringhals 3 And 4

Getting Ready The Replace The Steam Generators At Doel 3

Steam Generator Problems In Spain

3210 Replacing Steam Generators At Millstone 2

3211 Steam Generator Tube Evaluation By Ultrasonic Testing

3212 Development Of Uniqua In-Service Inspection Equipment For Reactor Pressure Vessels

3123 Moose Decontamination Robot Supports Nuclear Facility's Remediation Strategy

3124 Preconditioning Of PWRs 
3215 Demonstration Of PWR Full-System Decontamination

3216 Demonstration of Elevated pH

3217 Current Status Of PWR Primary Coolant Chemistry In The U.S.

3218 How Hydrogen Water Chemistry Impacts Shutdown Dose Rates In BWRs

3219 Worker Exposures Plunge At U.S. Nuclear Plants

3220 BWR And PWR Collective Radiation Exposure

3221 Automated Reactor Vessel Stud Removal System

3222 Hydro-Vac Shield

3223 Chemical Decontamination Of A PWR RHR System

3224 BWR Chemistry Guidelines Revision Committee Being Formed

3225 LOMI Decontamination Of Nuclear Reactors Reduces Exposure And Critical Path Time

3226 GPU Cuts Critical Path Time By Using EPRI Radwaste Desk Reference

3227 PWR Secondary Water Chemistry Guidelines

322810 CFR 20'S Impact On Computerized Dose Tracking

3229 Utilities Use Modified pH From Startup To Reduce Radiation Fields

3230 Reducing Costs And Radiation Exposures In The Nuclear Power Industry

3231 Convoy Leads The Way On Dose Reduction

3232 Re-Revising The Hiroshima Dosimetry Revision

3233 ABB-CE Applied ALARA Principles In The Design Of System 80+ PWR

3234 Use Of Image Transmission And Virtual Reality At Nuclear Plants

3235 Use Of Multimedia For Nuclear Power Plants

3236 Photogrammetry For Nuclear Power Plants

3237 Advanced Imaging Tools For Nuclear Power Plant Operation And Maintenance

3238 Piping System Inspection And Testing: Managing The Massive Results, Records, And Reports

3239 Reducing Radiation Dose By Effective ALARA Engineering

3240 Service Worker Dose Reduction: Whose Job is It?

3241 Control Rod Drive Mechanism Nozzle Inspection

3242 Reducing Exposure At U.S. Nuclear Plants

3243 PWR Primary Shutdown And Startup Chemistry Guidelines Complete

32441992 Year-To-Date Dose At U.S. BWRs

3245 Iron-Based Alloy Testing In BWR Chemistries

3246 Second Meeting Of The ISOE Steering Group

3247 Some Successful Techniques For Exposure Control

3248 Radiation Exposure Trends

3249 Chromium Coating To Reduce Activity Pickup

3250 PWR Primary Chemistry Update

3251 Radiation Exposure In 1992

3252 Robotic Vehicle

3253 Radiation Shielding

3254 Managing CRDM Nozzle Cracking

3255 Performance Monitoring Tool 
UK Goes For 20 msv Limit

3257 U.S. Nuclear Power Plant Performance Improves Again In 1992

3258 Dose Data From BWR Owner's Group RP/A Committee

3259 Nuclear Plant Discharges Too Low To Detect

3260 Present And Future Safety issues For Électricité De France (EdF)

3261 Listening To Reactor Pressure At The Boundaries For The Sounds Of Cracks And Leaks

3262 The Safety Of French Pressurized Water Reactors: A Regulator's Perspective

3263 Options For Leak Detection

3264 Good Experience From Operation Of Replacement Steam Generators

3265 Remote Handling Equipment Aids Bruce Nuclear Power Station

3266 EPRI'S Low Level Waste, Chemistry And Radiation Control Program

3267 European Utility Requirements For The Next Generation Of Nuclear Plant

3268 New Steam Generator For Doel 3

3269 Worker Protection During Contaminated Concrete And Steel Remediation

3270 More Circumferential Cracking Indications Found In Ringhals 2 Upper Head

3271 A Record-Breaking SG Replacement

3272 Neutron Detectors

3273 An Electronic Personal Dosimeter System

3274 Scaffolding Management For Waste And Dose Minimization

3275 Reactor Vessel Stuck Stud Removal And Stud Hole Repair

3276 Refurbishing Rather Than Replacing Reactor Coolant Pump Motors

3277 Service Water Restoration At North Anna

3278 Planning SG Replacement Pays Off For North Anna

3279 Lasers Make Light Work Of Sleeving

3280 Japanese Wrestle With Tube Problems

3281 Paving The Way For Full System Decontamination With The Fuel in

3282 Developing The Reactor Operating Procedures For Full-System Decontamination

3283 Laying The Foundations For The Field Implementation Of Full System Decontamination

3284 Preparing For Full System Decontamination At Indian Point 2: Utility Perspective

3285 The Road To Full RCS Decontamination

3286 Chemical Decontamination Workshop

3287 Surrogate Video Tour

3288 Temporary Shielding For RHR Piping

3289 Browns Ferry Nuclear Plant Unit 2 Cycle 6 Chemical Decontamination Proven Success

3290 Automating Pump Nozzle Inspection

3291 Automating Inspection Of Vessel Penetrations In French PWRs

3292 Japan Is Nearly Reaching The Limits Of Automated Inspection

3293 Combininng Al And NDE To Aid Pipework Repair And Inspection Decision

3294 Replacement Of Separator Shroud Bolts 


\section{UPDATE: ACE ON-LINE INFORMATION SYSTEM TO SWITCH TO CLOSE-UP 5.0}

Access to the databases of the BNL ALARA Center is available on-line, 24 hours a day to the ALARA community using the ALARA Center Exchange (ACE). Formerly, ACE access was possible only with the communications software, PC Anywhere III. However, new ACE users are finding this software very difficult to obtain, making the switch to CLOSE-UP 5.0 necessary. ACE uses only four basic commands, and the new four-page user manual (attached) includes all the instructions required to access and search the ALARA Center databases. AS OF MARCH 1.1994 THE ACE SYSTEM WILL BE ACCESSIBLE ONLY WITH CLOSE-UP 5.0.

If you own any other communications software, you can upgrade to CLOSE-UP 5.0 at a special low price of $\$ 69.95$. (The list price is $\$ 199$.) This limited-time offer is being made by the maker of CLOSE-UP, Norton-Lambert Corp., P.O. Box 4085, Santa Barbara, CA 93140, USA (Phone 805/964-6767; Fax: 805/683-5679). When ordering, you will need to supply Norton-Lambert with a xerox of the first page of the commications software manual, or a xerox of the program disk, that you now own. This special offer will expire on June 30, 1994.

Once you receive CLOSE-UP, please complete the form below, and mail or fax it to us. This will ensure that you receive notification of any changes to the system, on- and off-line assistance, and updated material on ACE.

Name:

Job Title:

Company:

Address:

City, State, Zip, Country:

Telephone: Fax:

Close-Up Registration Number:

Please return to: Maria Beckman Phone: 516/282-3228

BNL ALARA Center

Fax: $516 / 282-7091$ or $282-5810$

Building 703M

P.O. Box 5000

Brookhaven National Laboratory

Upton, NY 11973-5000 


\section{ACE: Reference Guide (Rev. 5)}

Please follow these instructions carefully and do not give commands that are not on this card.

In order to connect to $\mathrm{ACE}$ you must install the CLOSE-UP program and run CREMOTE (the part of CLOSE-UP which is designed for linking from a remote computer).

\section{General Comments on Using ACE.}

(1) The purpose of ACE is to provide a vehicle for rapid information search and retrieval.

(2) There are just four items on the ACE Quick Menu. You MUST follow the ACE commands on this card to retrieve information. You do NOT need any other commands that may be shown on the ACE screen.

(3) Each ACE menu command is activated by pressing the ALT key and a letter. You can not activate these commands by highlighting them and pressing ENTER. Each of these commands is a MACRO program. Please complete each command as described in this card, so that the macro program is not interrupted. (If you must interrupt the macro, type ESCAPE to stop the macro before you use the next ALT menu command).

(4) After typing a command, pause and let the modem and computers complete the command. Give the next command only after the screen has come to a stand still.

(5) The program CREMOTE is used to link to ACE. CREMOTE has its own menu and instructions. You will see this menu before you even connect to ACE. You MAY follow the CREMOTE instructions from the screen. Type ALT-R to call up the CREMOTE menu at any time. To remove the CREMOTE menu from the screen type ESCAPE once or twice.

2. Installing CLOSE-UP on your PC (for details, see Close-up Manual, page 3-1).

(1) Put the CLOSE-UP disk into the A: drive. At the DOS prompt type A:CINSTALL. Follow the directions on screen.

(2) The installation is essentially automatic (at the end of the installation process the program may propose a baud rate which is several times the transmission rate of your modem. This will be due to the data compression capabilities of modern modems. We recommend however, that you select a baud rate no higher than 19,200 for 9,600 and 14,400 baud modems and 2,400 for 2,400 baud modems).

(3) Optional: Add the directory C: \CLOSEUP to the PATH statement in your computer's Autoexec.bat file (e.g. $P A T H=C$ : $\backslash C L O S E U P$;). This way you can start CREMOTE from any directory.

3. Connecting to ACE (for details, see Closi-up Manual, page 3-4).

(1) Type CREMOTE at the DOS prompt (this will start the CREMOTE program and CREMOTE menu items will be displayed on the screen).

(2) The menu item phone and its drop-down menu item dial will 


\section{ACE: Reference Guide (Rev. 5)}

already be selected for you. Press

ENTER twice to select Manual Dial.

(3) Type the ALARA Center number and press ENTER. (Include any prefix digits for outside lines and long distance that you may require e.g. from inside the U.S. 1, 516282 3481).

(4) You should be connected to ACE and see the ACE Quick Menu.

(5) After a short while you will see a message Connection established. Press ENTER to begin session. When you press ENTER you will start using ACE.

\section{Browsing through a Database}

(1) Press ALT-B from the Quick Menu.

(2) Highlight a database with UP / DOWN arrow keys and press ENTER. (As each database is highlighted its contents will be described by an enhanced line at the bottom of the screen).

(3) To see other screens of a form, press PAGEUP or PAGEDOWN keys (not UP / DOWN arrow keys).

(4) To see the next form, press F10; to see previous form, press F9.

5. Searching through Keywords

(1) Press ALT-K from the Quick Menu.

(2) Highlight a database with UP / DOWN arrow keys and press ENTER. (A partial query will be started at the top of the form. Below that, in a window, an alphabeticuily sorted list of all the KEYWORDS will be displayed, starting with the letter 'A').
(3) If the keyword you require starts with another letter start typing your keyword. It will appear near the top of the list. (e.g. start typing "zinc" to see the keyword "zinc injection" near the top of the list).

(4) Highlight the keyword and press ENTER. All forms with your keyword will be displayed. (please note item 8 below).

(5) Press PAGEUP or PAGEDOWN keys to see other screens of a form.

(6) Press F10 to see the next form on the subject; press F9 to see the previous form.

\section{Printing a Form}

(1) Make sure in the CREMOTE Print menu you have the selection Print at Remote only (for details, see Close-Up manual, page 5-23).

(2) Turn your printer ON.

(3) Press ALT-P while looking at the form you want to print. The form will be printed on your printer. (Note: Do not install any new printers. An all purpose printer has already been setup for you).

7. Printing to a File on your Fixed Disk

(1) Select Print at Remote Spooler in the CREMOTE Print menu (for details, see Close-up manual, jage 5-24).

(2) Press ALT-P while looking at the form you wish to print (" ${ }^{2}$ rinting to the spooler file and then printing later off-line will save long distance charges).

8. To see the 'Quick Menu'

(1) Press ALT-Q from any screen. (If the $A L T-B$ or ALT-K command has not 


\section{ACE: Reference Guide (Rev. 5)}

been completed, e.g. after these commands you do not wish to select a database or Keyword but to see the Quick Menu again, then stop the macro program by pressing ESCAPE before pressing $A L T-Q)$.

9. Exiting ACE (Close-up manual, p. 3-5)

(1) Press ALT-Q

(2) Press ALT-R from any screen. This will bring back the CREMOTE menu.

(2) Phone and Hang-up will already be selected for you from the CREMOTE menu. Press ENTER twice to hang-up the line.

10. Setting up ACE in the Phone Book (for details, see Close-up Manual, page 3-5).

(1) Press ALT-R to bring up the CREMOTE menu.

(2) Select Phone and then Phone Book Editor. (This brings up the editor menu).

(3) Select Phone Book

(4) Follow the instructions on the screen.

(5) For baud rate, we recommend you use Default.

11. Capturing Screens during an ACE session

(1) Whenever you wish to capture and save information in a screen, press ALT-R to bring up the CREMOTE menu.

(2) Select Record and then Save Current Screen. Follow CREMOTE prompts to save screen.
(3) Use the ESCAPE key to remove the CREMOTE menu from the screen

(4) Saving, and then playing back saved screens is much quicker than printing on-line. You may then print from saved screens off-line to save long distance charges.

12. Playing Back Screens

(1) Exit ACE (see item 9 above).

(2) In the CREMOTE menu select Playback and then Display Saved Screens

(3) Follow screen instructions.

13. Printing captured screens

(1) Once the captured screens are displayed you may print them one-by-one using the Print Screen key on your personal computer.

14. Recording your ACE session

(1) You may record the whole or any part of your session while connected to ACE. You may then play it back off-line in fast or slow motion.

(2) While connected to $A C E$, type ALT-R to bring up the CREMOTE menu.

(3) Select Record and say Yes to Record Session

(4) Accept CREMOTE's suggestion to delete old recording file and start a new one.

(5) Your session is now being recorded. Type ESCAPE to remove CREMOTE menu from screen.

(6) To stop recording any time, follow steps (1) to (5), but select No in step (3) above. 


\section{ACE: Reference Guide (Rev. 5)}

15. Playing back the ACE Session

(1) Exit ACE by hanging up (see item 9 above).

(2) Select from CREMOTE Playback and Playback Saved Session.

(3) Follow screen instructions for fast / slow motion playback and stopping playback.

16. Exiting CLOSE-UP REMOTE

(1) Press ESCAPE once or twice, until a message appears Press ENTER to exit Close-up (see manual, p. 3-5).

(2) Press ENTER.
Note 1: The elapsed long distance time is always shown on the top right of the screen while you are connected to $A C E$.

Note 2: You may ask us for advice by opening the Chat window with the command ALT-C. If we are available near the host computer we will respond.
In case of problems, you may contact us by phone at either (516)282-3228 or (516)282-4012.

\section{BNL ALARA CENTER TELEPHONE NUMBER REFERENCE GUIDE}

To access ACE by computer and modem

(516)282-3481

To fax a document to yourself through a fax machine (pick up the hand set of your fax machine and dial this number from your fax machine only. Follow the voice prompts. Password is not required)

(516)282-7361

To apply for access to ACE

(516)282-3228

To apply for our newsletter 'ALARA Notes'

(516)282-3228 


\section{ATTENTION}

We are updating our mailing list for ALARA Notes.

1. If this is the first time you have received ALARA Notes and wish to be added to the mailing list, then you must complete and mail this form.

2. If you regularly receive ALARA Notes and have no address change to report, then do not complete this form.

3. If you wish to report a change of address or wish to stop receiving ALARA Notes, please complete and mail this form.

4. The information in ALARA Notes is kept in the computers of the ALARA Center and is continually updated. We also maintain information on ALARA research, health physics technology at nuclear power plants, and processes and practices found effective in dose reduction. This material is available to the ALARA community online by means of a personal computer and a modem. An application to access the system is available by calling Maria Beckman at the ALARA Center, (516) 282-3228.

Please mail this form to: Maria Beckman, ALARA Center, Brookhaven National Laboratory, Building 703M, P.O. Box 5000, Upton, NY 11973-5000 USA.

Please add me to the mailing list for ALARA Notes

Please change my mailing address

Please remove me from the mailing list for ALARA Notes

Name:

Job Title:

Organization:

Address:

City, State, Zip Code:

Country:

Telephone Number: Fax Number:

May we have your comments on ALARA Notes: 
Information Request Form

BNL ALARA Ceriter Daitabase

1. Title:

2. Investigator(s):

3. Project Manager:

[name, organization, address, phone, and fax number]

4. Objectives:

5. Comments: [Describe the background, perspective, progress, or significant findings .]

(continued on next page)

Return to: Dr. Tasneem A. Khan, Brookhaven National Laboratory, ALARA Center, Building 703M, P.O. Box 5000, Upton, NY 11973-5000. Phone: 516-282-4012. Fax: 516-282-7091. 
6. Remarks/Potential for dose limitation: [Indicate any potential beneficial or detrimental dose impacts. Note any important conclusions.]

$\begin{array}{lll}\text { 7. Duration - From: } 19 & \text { To: } 19 & \text { 8. Funding: [Monetary amount or person-years] }\end{array}$

9. Status: [Indicate the degree of completion, i.e., PROPOSED, INITIATED, IN PROGRESS, or COMPLETED.]

10. References: [Recent reports, articles, or publications]

11. Key Words: [Indicate the broad areas related to the project.] 

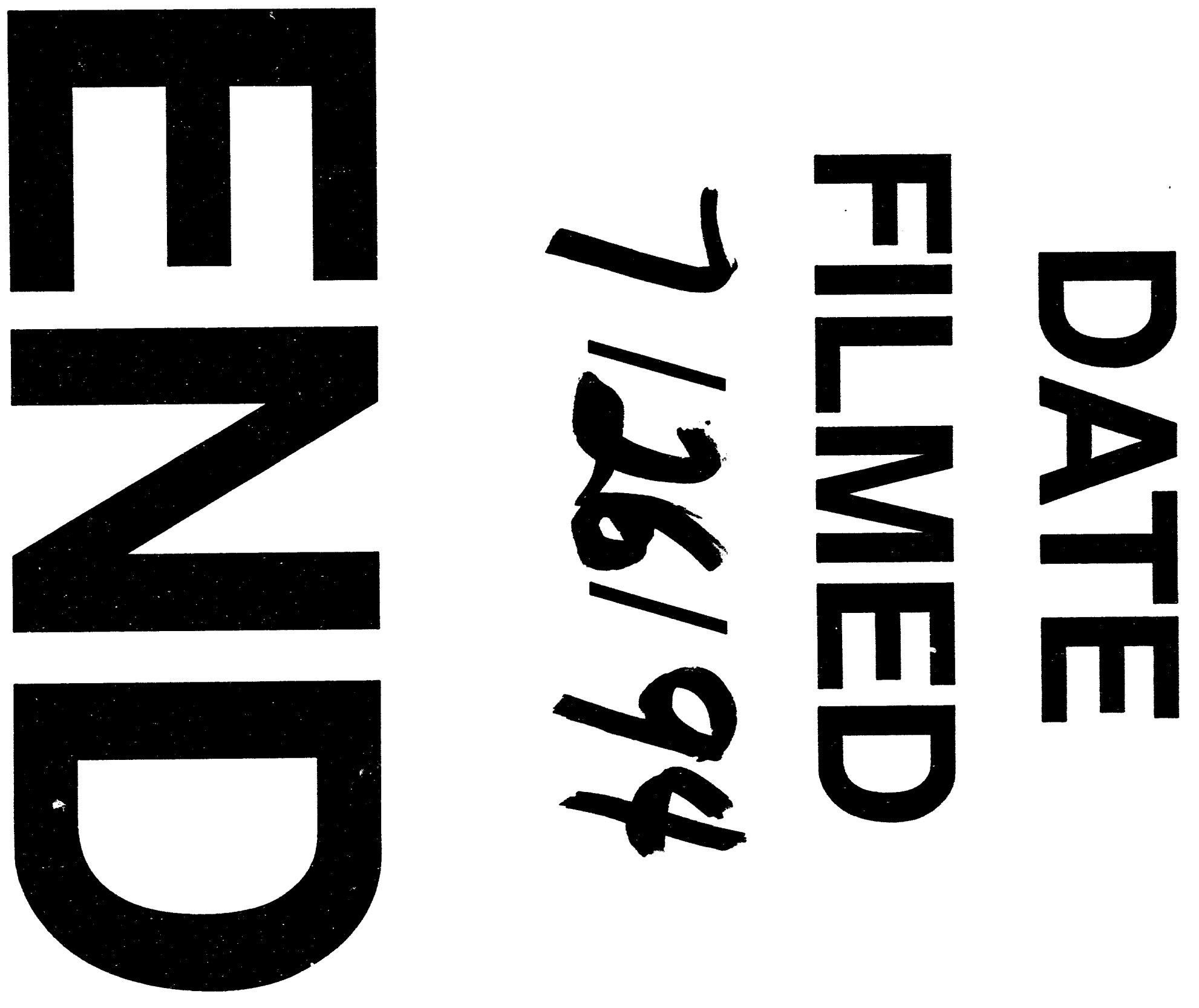


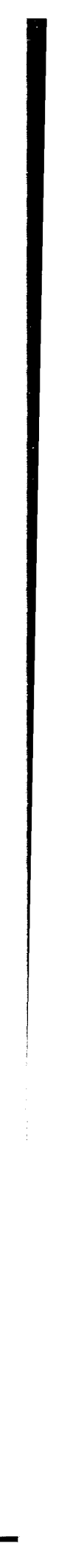

